Yohanan Friedmann, Shaykh Ahmad SirhindI 


\section{TABBLE OF CONTENTS}

FOREWORD......................... ii

A NOTE ON TRANSLITERALION................ v

CHAPNER I - THE SOURCES................... I

CHAPTER II - THE CUNCEPT OF TAJDID........... 17

CHAPIER III - THE SELF-IMAGE OF AHMAD SIRHINDI.... 29

CHAPTER IV - PROPHECY AND SAINTHOOD......... 41

CHAPTER V - SIRHINDI'S VIEW OF THE ISLAMIC TRADITION I..................... 55

1. Sunna, Shari'a and Tariqa................. 55

2. The concepts of Islām and infidelity (kufr). 68

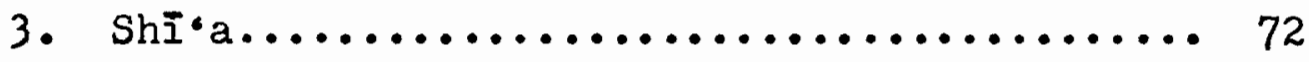

4. Falsafa.......................... 76

5. Theology (kalām).................. 80 CHAPIER VI - SIRHINDI'S VIEW OF IHE ISLAMIC

TRADITION II..................... 84

1. The early șufis $\ldots \ldots \ldots \ldots \ldots \ldots \ldots \ldots \ldots . \ldots 8$

2. Ibn al-`Arabi.................... 90

3. The Naqshbandi order.................. 100

CHAPTER VII - THE INDIAN ENVIRONMEIT........... 103

CHAPIER VIII - SIRHINDI AND THE IIUGHUL COURT..... 115

CHAPIER IX - THE JUDGIVENT OF POS'TERITY......... 130

1. Abd al-Haqq Muhaddith Dihlawi and 'Abd

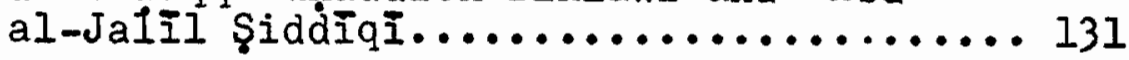

2. The hagiographic literature............ 139 
3. The controversy over Sirhindi during the reign of Awrangzēb...................... 142

4. Sirhindi's image in the seventeenth

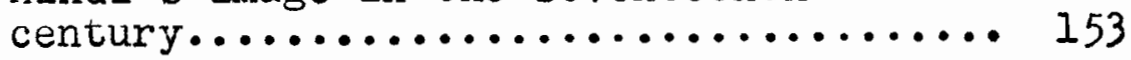

5. The eighteenth century................ 156

6. Wakil Ahmad Sikandarpürí.............. 160

7. The modern period.................... 162

CHAPIER X - CONCLUSICN.................. 173

APFEWDIX A........................ 177

A $F$ PENDIX B......................... 180

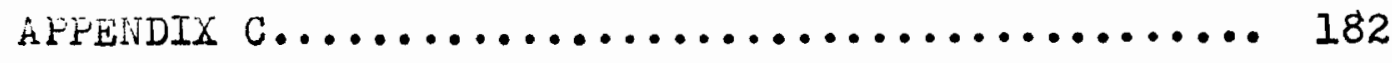

NOTES TO CHA FER I...................... 184

CliAPRER II........................ 193

CHAHLER III...................... 199

CHIPER IV..................... 203

CHATER V..................... 206

CHAPLER VI................... 217

CHAPIER VII.................... 221

CHATER VIII................... 225

CHAPPER IX.................... 231

CHAPTER X....................... 243

BIBLIOGRIFHY.......................... 244 
SHAYKH AHMAD SIRHINDI

AN OUTLINE OF HIS THOUGHT AND A SIUDY OF HIS IMAGE

IN THE EYES OF POSTERITY

by

YOHANAN FRIEDMANN

A thesis submitted to the Faculty of Graduate Studies and Research in partial fulfilment of the requirements for the degree of Doctor of Philosophy.

Institute of Islamic Studies, McGill University, INontreal.

June 1966.

(c) Yohana Friedmann 1967 


\section{FOREWORD}

A student of the history of Islām in India is soon confronted with the name of Shaykh Ahnad Sirhindi $(1563 / 4-1624)$. He was a contemporary of the emperors Akbar and Jahāngĩr, was given by his disciples the honorific title of the Renewer of the Second Millennium (mujaddid-i alf-i thāni ) and is the author of a celebrated collection of letters that came to be known as Maktūbāt-i Imām-i Rabbānī. It has been a near consensus of modern historians that Sirhindi brought about major changes in the development of Islām in India. He is said to have reversed the heretical trends of the period of Akbar, restored the pristine purity of Islām and inspired the orthodox reforms of Awrangzēb. The purpose of this thesis has been to re-examine the evidence for this assessment. During the process of research a considerable amount of hitherto unknown material bearing on the reception of Sirhindi's ideas by his contemporaries and by posterity has been uncovered. It has also become clear that Sirhind''s known works have been used in a tendentious manner in modern historical works. Modern historians have laid great emphasis on SirhindI's demand for the strict implementation of the shari'a by the state 
and for the purification of Islām from late accretions, to the virtual exclusion of other subjects which are not less important in Sirhindi's thought and constitute the bulk of his writings. For Sirhindi was primarily a şūfĩ. He was not a thinker concerned mainly with the question of religion and state and was not regarded as such by his contemporaries.

The present writer has tried to present a more balanced picture of Sirhindi's thought. An effort has been made to concentrate upon those aspects that have hitherto been neglected. 'The work does not claim to be exhaustive and much more research will be necessary before a final assessment of Sirhindi's place in the history of taşawwuf can be made. The present writer is convinced that further studies of Sirhindi will have to be made against the background of Ibn al-'Arabi and 'Alā' alDawla al-Simnānī rather than that of Akbar and Jahāngīr. It is a pleasant duty to express my gratitude to those who assisted me in the preparation of this work. Professor C. J. Adams, Director of the Institute of Islamic Studies at WicGill University, has read the whole thesis and offered valuable criticism and suggestions. Professor Adams was also of great help in arranging my trip to India in the fall of 1964. Many difficult aspects of Sirhindi's thought have been clarified in my 
discussions with Professor H. Landolt. Sincere gratitude is due to Professor Khalíq A ḩmad Nizāmi of Aligarh Muslim University, whose scholarship and hospitality I had the privilege to enjoy while visiting Aligarh in the academic year 1964-65. I am also grateful to my friend R. Nettler, but for whose help the English style of the thesis would have been worse than it is. My studies at McGill University in the years $1962-63,1963-64$ and 1965-66, as well as my trip to India in 1964-65, would have been impossible without the generous financial help of the Canadian Friends of the Hebrew University in Montreal. I should like to offer thanks mainly to Dr. S. Cass, National Chairman, Academic Awards Committee, and to IN. S. Risk, National Honorary Secretary, for their continued interest in my work. 


\section{A NOTE ON TRAIISLI'EERA'ION}

The following system of transliteration of Arabic characters has been used:

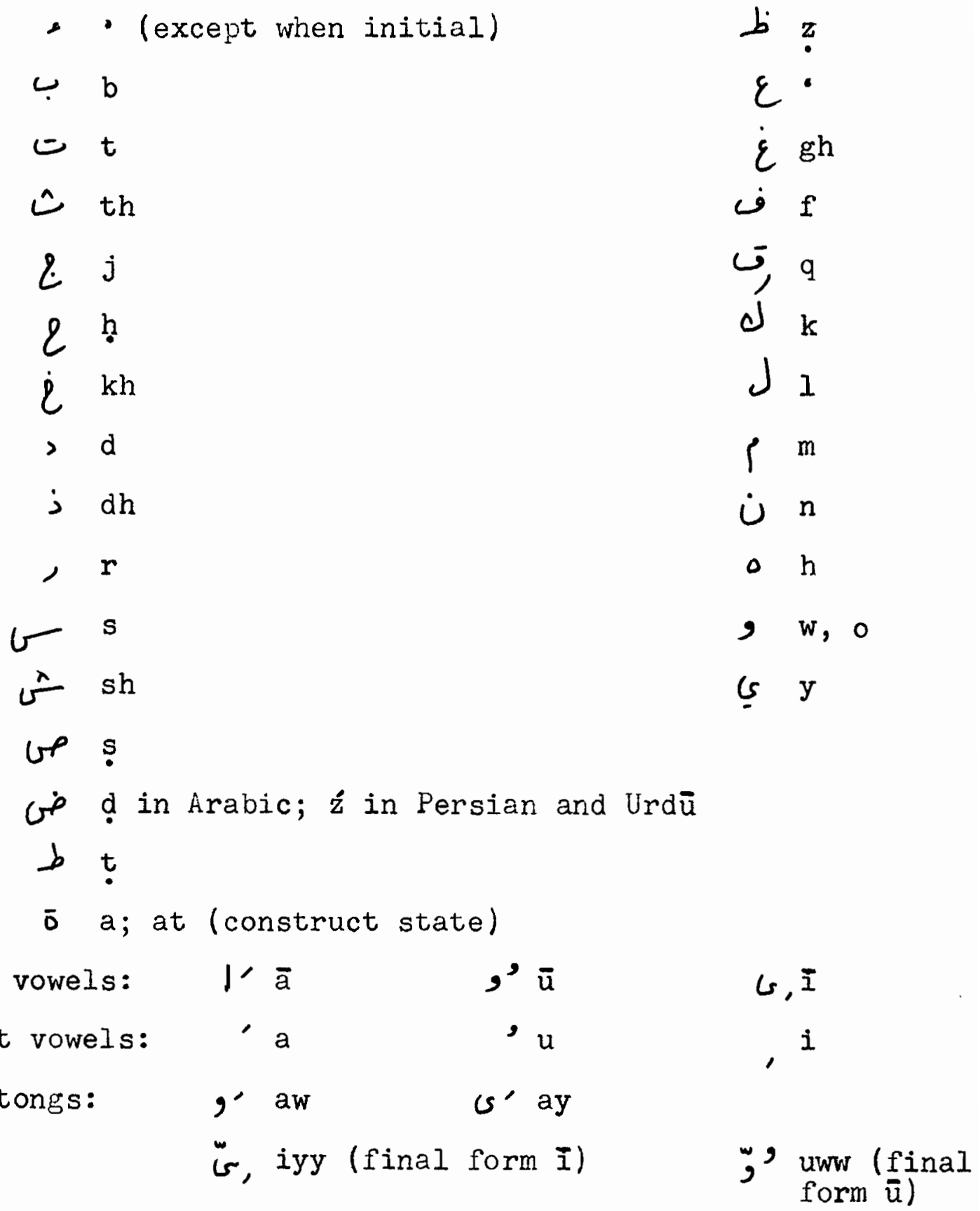


Persian and Urdū additions to the Árabic alphabet:

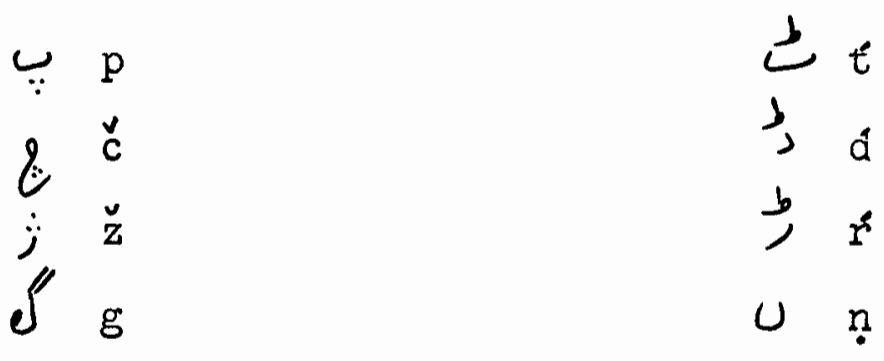

Additional Urdū vowels:

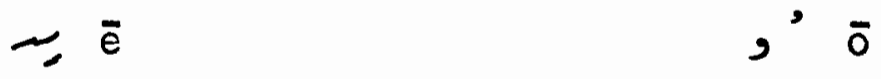

Urd $\bar{u}$ aspirated consonants have been marked by the addition of $\underline{h}$. 


\section{CHAPTER I}

\section{THE SOURCES}

The main source materials for the present study are the following:

1) Epistles and other works by Sirhindi.

2) Polemical works by Sirhindi's opponents and his supporters' replies.

3) Hagiographies.

4) Modern analyses and evaluations of SirhindI's thought and significance. ${ }^{1}$

1) The most important work in the first group is Sirhindi's letters which came to be known as Maktūbāt-i Imām-i Rabbānī. Though many manuscripts of this work are available in various libraries and the Maktūbāt have been lithographed several times, 2 as well as translated into Turkish, ${ }^{3}$ Arabic $^{4}$ and Urdū, 5 we do not have the benefit of a scholarly edition of the text or a part of it. This is somewhat surprising and disappointing as these letters have been repeatedly hailed as a landmark in the development of IsIām in India; one must not forget, however, that the preparation of a scholarly edition of this difficult work, comprising nearly 900 pages, would be a stupenduous task requiring a team of scholars working 
over a prolonged period of time. Thus the student is frequently treading on uncertain ground when analysing various details of SirhindI's thought.

The Maktūbāt are divided into three volumes which were completed, according to their chronograms, in 1025/1616-17, 1028/1618-9 and 1031/1621-2 $2^{6}$ and contain 313,99 and 122 epistles respectively. 7 The first volume started after 1008/1599-1600, the year in which Sirhindi became associated with Muhammad al-Bāqi bi-'Ilāh. It is important to point out that the letters were arranged in the present order in Sirhindi's lifetime and that this order is chronological. This assertion is based not only on the nearly contemporary tradition according to which Sirhind $I$ himself decided upon the ordering of the letters and appointed the editors, ${ }^{8}$ but also on conclusive internal evidence. 9 This not only enhances our confidence in the authenticity of the material, but also enables us to follow the development of Sirhindi's thought and to detect possible changes in his fields of interest and attitudes throughout his life.

The 534 letters of the three volumes are addressed to nearly 200 persons. Most of these are sūfis and the letters deal with a variety of subjects connected with șūfĩ thought. Only a small number of recipients 
belong to the Mughul officialdom and not more than seventy letters have been addressed to them. The significance of this for the over-all evaluation of Sirhindi's place in the history of Islām in India will be discussed in due course; for the time being let us only state that the letters addressed to the Mughul officials have received attention out of proportion with their actual weight in the collection as a whole. Each of the three volumes was assembled by one of Sirhindi''s disciples ${ }^{10}$ who also undertook minor editorial tasks, such as providing each letter with 2 brief introduction, stating the identity of the addressee and the nature of the subject or subjects dealt with in the letter. In many cases Sirhindi himself acknowledges the receipt of the letter in reply to which he is writing and summarizes it. These summaries are very helpful in understanding the background of the letters, especially in view of the fact that, barring insignificant exceptions, 11 we do not have at our disposal the full text of the letters received by Sirhindi. Occasionally, due to lack of time, Sirhindi found it difficult to answer all the questions addressed to him; ${ }^{12}$ in such cases he would refer his disciples to earlier letters in which their questions had been discussed. ${ }^{13}$ We can learn from this fact that Sirhindi's letters were 
available not only to their original recipients, but also to other persons interested in the subjects discussed in them. In fact, in at least one instance SirhindI instructed one of his disciples residing in the Dakhan to prepare several copies of his letters, 14 apparently for possible circulation in the future. It can therefore be assumed that the letters were "open" to some extent and that they were fairly well known in the şūfi circles of the time. This notwithstanding, the letters are very repetitious and many of the subjects are discussed in them over and over again.

Not all of Sirhindi's letters were prepared in response to questions. Some were written on his own initiative or at the request of people who wanted their case to be recommended to a government official upon whom Sirhindi was believed to have wielded some influence. We shall discuss these letters later in our study; one point concerning them must, however, be made now: just as we do not have at our disposal the text of the questions sent to SirhindI by his disciples, we do not have the replies he received from people whom he had approached upon his own initiative. To gauge their response we must glean our evidence from scattered details in Sirhindi's letters. This method cannot be 
expected to furnish us with fully satisfactory answers concerning the extent to which Sirhindi was influential with these people. This deficiency is particularly severe when we come to deal with Sirhindi's influence on high officials of the Mughul court. We lack the very material which would presumably supply us with the answer to the all-important question of whether SirhindI's influence on the nobles of the court and on Jahāngir himself was as decisive as many writers have believed it to be.

Another difficulty in dealing with the Maktūbāt lies in the fact that only a small number of the nearly 200 addressees can be properly identified with the help of the sources presently available to us. The virtual anonymity of most of them is a great hindrance in our endeavour to evaluate the significance of each letter. It comes to the fore especially when we try to explain the apparent differences and contradictions in Sirhindi's views as expressed in different places. We tend to think that many of these contradictions stem from Sirhindi's belief that esoteric doctrines should be revealed only to those who are adequately prepared and capable of rightly understanding them. He therefore withholds certain "secrets" from one disciple, but does 
not hesitate to reveal them to another one. Considering Sirhindi's strong views on the necessary distinction between "awāmm and khawāşs, 15 this seems to be the most plausible explanation of these contradictions; however, we cannot yet furnish a conclusive proof for it. However serious these difficulties may be, the Maktūbāt still remain the basic and indispensable material for the analysis of Sirhindi's thought. Sirhindi's other works are shorter, but have the advantage of being comprehensive expositions of a subject. They are interesting in more than one way. The Epistle on the Refutation of the ShI'a (Risàla dar Radd-i Rawāfiź), which has been published as an appendix to the lithographic editions of the Maktūbāt, ${ }^{16}$ is apparently Sirhindi's earliest work. It was compiled during Akbar's reign, before SirhindI's initiation into the NaqshbandI order in 1008/1599-1600, ${ }^{17}$ and can be considered the first manifestation of his sunni fervour.

Ithbāt al-Nubuwwa is Sirhindi's only work written entirely in Arabic, though Arabic passages are abundant in the Maktūbāt and in the other works. Its date cannot be established exactly, but it was also written before 1008/1599-1600. It presents the familiar arguments to prove the necessity of Prophecy in general and the Prophecy of Muhammad in particular. Parts of it 
are identical with chapters in al-Ghazāli's al-Mungidh min al-Daläl ${ }^{18}$ it draws heavily upon other classical kalām works proving the necessity of Prophecy, and it does not break any new ground. It is interesting solely because Sirhindi expresses in it his views on the situation of Isläm in India during the reign of Akbar and reproduces in its preface a debate on the subject of Prophecy which he claims to have held with Abu l-Faźl. Though Abu 'l-Faźl is not mentioned explicitly, it is clear that SirhindI is alluding to him when he says: "I debated with a man who studied the science of falsafa, learned from the books of the infidels, claimed for himself $\underline{\mathrm{a}} \underline{I}-\underline{\underline{f}} \underline{\mathrm{a}} \underline{\mathrm{d}} \underline{\underline{I}} \underline{\underline{1}} \underline{\mathrm{a}} \quad \underline{\mathrm{w}} \underline{\mathrm{a}} \quad \underline{\mathrm{a}} \underline{1}-\underline{\underline{f}} \underline{\mathrm{a}} \underline{\mathrm{d}} \underline{\underline{1}}$, led people astray and went astray himself in the investigation of Prophecy and its occurrence to a certain man . ." (nāzartu ba'd man gara"a 'ilm al-falsafa wa akhadha min kutub al-kafara hazzan wa idda ‘ $\bar{a}$ al-fadila wa al-fadl wa agdalla al-nās wa dalla fí tahgĩg al-nubuwwa wa thubūtihā 11-shakhs_mu'ayyan). 19 The book's connection with Abu - l-Faźl and its non-şüf character are our reasons for suggesting that it was written before 1008/1599-1600.

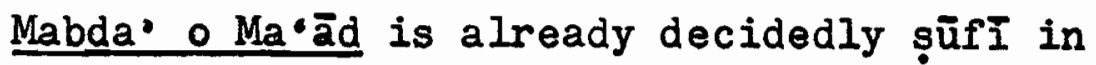
character. It was written between 1008/1599-160020 and $1019 / 1610^{21}$ and Sirhindi refers to it several times in the first volume of the Maktūbāt. ${ }^{22}$ Both Zubdat al-Magāmāt 
and Ḥaźarāt al-Quds quote it extensively. 23 It consists of 54 short chapters dealing with a variety of șüfi subjects. It is very different in form and content from the two earlier works and is indicative of the tremendous change which Sirhind $\bar{I}$ underwent as a result of his association with Muhammad al-BāqI bi-illāh. Mabda' o Ma'ãd is an esoteric work. In several places in it SirhindI says that none before him had been given the mystical insights included in this book. ${ }^{24}$ In view of the extensive quotations in the contemporary material, Mabda' O Ma'ād seems to have been a very popular book in the seventeenth century, very much unlike its position in modern research which has virtually ignored it. Ma`ārif Laduniyya ${ }^{25}$ is also a șūfi work, very much similar in structure and content to Mabda' $0 \mathrm{Ma} \cdot \bar{a} d$. It is not dated and one can say with certainty only that it was written after Sirhindi had joined the NaqshbandI order.

In addition to the works described above, Sirhindī's biographers mention: al-Risāla al-Tahliliyya, Risālat al-Mukāshafāt al-Ghaybiyya, Risālat Ādāb alMurIdĪn, Ta'līgāt al-'Awārif, Sharh al-Rubā'iyyāt liI-Khwāja Abd al-BāqI. ${ }^{26}$ The first three of these works do not seem to be extant. At least part of the Ta'ligāt al-'Awārif, which was a partial Arabic commentary 
on AAwārif al-Ma ā̄if of SuhrawardI, 27 may be preserved in letters 117, 118 and 119 of the third volume of the Maktūbāt. 28 Sharh al-Rubā'iyyāt is mentioned by Storey, 29 but was not available to us.

Thus, on the basis of philological analysis of the sources, Sirhindi's creative life is divisible into two periods. In the first period, which can be characterized as pre-șüf and which lasted till 1008/ 1599-1600, Sirhind $\bar{i}$ wrote the Radd-i Rawāfiź and the Ithbāt al-Nubuwwa. In the second or sūfi period, from that year and on, he wrote all his other works. It is important to point out that the șufi period cannot be further divided on the basis of our literary evidence. No literary evidence is extant from the period of "intoxication" (sukr) through which Sirhindi claims to have passed. 30 Sirhindi claims to have written to his preceptor Muhammad al-Bāqĩ bi-'llāh highly "intoxicated" verses in which he denied the existence of any difference between Islām and infidelity; ${ }^{31}$ however, we do not find these verses in Sirhindi's letters to al-BāqI bi-'llāh, which constitute the first part of the first volume of the Maktūbāt. On the other hand, the Maktūbāt contain much material that can be considered "intoxicated" by any standards, even in letters which Sirhindi wrote very late in his life. 32 Hence literary evidence does not 
corroborate the view that Sirhindi started as an

"intoxicated" șūfI and developed into a "sober" one. We shall discuss the significance of this later.

2) It is indicative of the direction which the research on Ahmad SirhindI has taken that hardly any of the numerous works dedicated to the refutation of Sirhindi's views has been published. On the other hand, several of his supporters' replies have appeared in print. Perhaps the most important polemical work against Sirhind $\bar{I}$ is included in the unique manuscript Mukhtașar Ma ‘ārij al-Wilāya fī Madārij al-Hidāya yā Ma“ärij al-Awliyā' fi Madārij al-Aşfiyā'. The author is Abd Allāh Khwēshgi Quşūi who completed the book in Awrangābād on Rajab 24, 1094/JuIy 24, 1683.33 It is a book containing şūfi biographies of considerable importance. 34 Two of them include material relevant to our subject. The first is the biography of the wellknown Shaykh Abd al-Ḥaqq Muhaddith DihlawI (1551-1642). Most of it consists of a long epistle in which 'Abd alHaqq expresses his strong disapproval of Sirhindi's views. ${ }^{35}$ The second is the biography of Sirhindi himself. 36 It includes quotations from Sirhindi's letters that aroused opposition of his contemporaries and from polemical works written in refutation of Sirhindi's views, especially Kāsir al-Mukhālifīn. 37 Also included 
is the text of an important decree concerning Sirhindi, which was issued upon the instructions of Awrangzēb. It will be discussed in detail later in this work.

Other anti-Sirhindi polemical works originated in al-Hijāz and were written in response to an istiftā' from India that reached al-Hijjāz in Jumādā II, 1093/JuneJuly 1682.38 We have two works by Muhammad b. "Abd alRasūl al-Barzanjī, a Shāfi'I s̄âlim of al-Madina. The first of them, Qadh al-Zand wa Qadab al-Rand fi Radd Jahālāt Ahl al-Sirhind, 39 is an Arabic work completed on Rajab 15, 1093/July 19, 1682.40 It seems that it was also translated into Persian under the name Gardan Shikan, 41 probably for circulation in India. Another work by the same author is al-Nāshira al-Nājira li-'lFirga al-Fājira, ${ }^{42}$ completed on Muharram 7, 1095/December $26,1683.43$ It was apparently written to counter the pro-Sirhindi campaign launched in al-Hijāz at that time by Muhammad Bēg al- đzbaki whom we shall discuss later. It is the last of the ten books which al-BarzanjI claims to have written in refutation of Sirhindi and his followers. 44 Among these ten works were, in addition to the two extant ones, al-Ighāra al-Mușbiha, Idāalat alNibrās ${ }^{45}$ and a Persian work called Khayl Allāh bar Sar-1 Khayr Allāh. 46

Another work of the same period and of very 
similar character is al-'Aşab al-Hindi li-'stīsāl

Kufriyyāt Ahmad al-SirhindI by H̦asan b. 'AlI, a Hanafi -ālim of Makka. 47 It is not dated, but was also written in response to the istift $\bar{a}^{.}$of 1093.48

Many more works of the same kind seem to have been written at that time. A list of authors containing 16 names is given in al-Nāshira al-Nājira. 49 The most prominent among them seems to have been al-Barzanji's teacher, IbrāhĪm al-KurdI al-Kūrānİ. 50

The outstanding supporter of Sirhind $\bar{I}$ in the controversy of 1093-1095 was Muhammad Bēg al- Izbaki. He came to al-Hijāz from India 51 and wrote "Attiyyat alWahhāb al-Fāşilla bayna al-Khața wa al-Șawāb. ${ }^{52}$ The book was finished on RabI. I 2, 1094/March 31, 1683, 53 between al-BarzanjI's Qadh al-Zand and his al-Nāshira al-Najjira. It was intended to undermine the charges levelled against Sirhindi by trying to show that the Arabic translation of the Maktūbāt, prepared for the Hijāzi 'ulamā', were misleading. It is important because of extensive quotations from the istifta. of the Indian 'ulamā', which does not seem to be extant elsewhere. 54

The importance of the above-mentioned polemical works should not be underestimated. Not only do they dispel the widely accepted view that Sirhindi was 
unanimously accepted as "orthodox" in India and elsewhere; they also give us a valuable insight into the image of Sirhind 1 that was prevalent in the seventeenth century. From a broader historical view-point, we learn from them about the prestige enjoyed by the 'ulama'. of al-Hijāz among their Indian counterparts, and about the connections between the culama' of the two countries.

The rehemence of the polemics surrounding SirhindI abated in the eighteenth century and it is only with hesitation that we include some of Shāh Wali Allāh's works in this category. Apart from the wellknown Fayşala-yi Wahdat al-Wujūd wa al-Shuhūd which has been published and widely commented upon, Shāh WalI Allāh wrote two epistles relevant to our discussion which are still in manuscript. One is Shawāhid alTajdidd $^{55}$ which gives us valuable insight into the understanding of the concept of tajdId in the eighteenth century. The other one, which has no title, deals with the concept of khilla and explains in this connection Sirhindi's role at the beginning of the second millennium. 56 Other eighteenth century works concerned with the question of wahdat al-wujūd versus wahdat alshuhūd have been described elsewhere. 57 In addition to these we have the short but highly interesting statement by "Abd al-'AzIz Dihlawi, who states that Sirhindi's 
contribution to the şūf $\overline{1}$ thought was the introduction of the concept of khilla. 58

In the late nineteenth century SirhindI found a vigorous defender in the person of WakIl Ahmad Sikandarpūrī.59 Prompted by a feeling that people again show interest in al-Barzanji's works, Sikandarpūrī wrote in 1308/1890-1891 al-Kalām al-Munji bi-Radd Irādāt al-Barzanji. 60 It is written in florid Arabic and contains a detailed refutation of Qadh al-Zand.

Sikandarpūri wrote also two other works in defense of Sirhindi. His Hadiyya Mujaddidiyya ${ }^{61}$ deals with Abd al-Haqq's epistle, while Anwār Ahmadiyya was written to refute Mukāshif al-Asrār by an otherwise unknown Gujarātí.62

Sikandarpürī's works seem to be the last written according to the pattern common in mediaeval Muslim polemics. Works written in the twentieth century, whether attacking SirhindI or defending him, are decidedly different in form, content and intent and will be discussed separately.

3) Hagiographies of SirhindI are numerous and no attempt has been made to exhaust material of this sort. It is full of legendary material such as miracle stories, traditions according to which SirhindI was predicted, description of cosmic events accompanying his 
birth and death and the like. There are also a number of stories describing SirhindI's miraculous impact on political events. These are perhaps the most interesting aspect of the hagiographies as they contain adumbrations of Sirhindi's image in the 20th century.

We have utilized two works from this category written by SirhindI's contemporaries. Haźarāt al-Quds by Badr al-Dīn Ibrāhīm Sirhindi ${ }^{63}$ contains chapters on Sirhindi's life, his spiritual experiences, miracles, daily routine and tries to refute the views of his critics. It also deals with his sons and disciples. Zubdat al-Magāmāt by Muḥammad al-Hāshim b. Muḥammad alQāsim al-Babaghāni al-Badakhshān $\bar{I}^{-64}$ contains biographies of Muhammad al-Bāqi bi-’llāh, of Sirhindi and of his disciples and copious quotations from the Maktūbāt and the other sources.

4) The description of modern works dealing with Sirhindi's thought and significance is intimately connected with the analysis of his image in the 20th century. As we consider this analysis an essential part of our study, we shall deal with it in detail in a special chapter. We would therefore prefer not to describe the 20th century sources in this introductory section, but rather to combine the bibliographical survey with the analysis of the modern works in Chapter IX. 
One remark remains to be made here. The reader who is familiar with the crucial historical role which Sirhind $I$ is frequently said to have performed in the seventeenth century India might wonder why no historical sources have been mentioned in our present survey. The situation is that except for Jahāngīr's memoirs we have virtually no strictly historical material concerning Sirhind $\bar{I}$ at our disposal. Practically all our sources are șüfi and theological. The significance of this fact for the over-all assessment of Sirhindi's role in the history of Islām in India can hardly be overestimated. 


\section{CHAPTER II}

THE CONCEPT OF TAJDID AND THE MILLENNIUM

The ideas of religious renewal (tajdId) and revival of the prophetic usage (ihhya. al-sunna) developed at a very early stage of Islamic history. The concept of ibya $\bar{a}^{\prime}$ al-sunna, which is frequently used in the early Islamic literature, stemmed from the conviction that the period of the Prophet had been the ideal which ought to be recaptured. Revival of the prophetic usage has therefore always been one of the most meritorious actions that could be performed by a Muslim. ${ }^{1}$ The famous saying of the Prophet that "the best of my community is the generation in which I was sent, then those who follow them, then those who follow them . . ." (khayr ummatI al-garn alladhI bu'ithtu fīhi thumma alladhina yalūnahum thumma alladhina yalūnahum) is only one of the numerous traditions idealizing the earliest period of Islamic history. ${ }^{2}$

On the other hand, the concept of tajdid, which ia later times appears to have become almost indistinguishable from that of ihy $\bar{a} \cdot$ al-sunna, was much less frequent and originated in material of a different 
kind. The hadith "God will send to this community on the eve of every century a man who will renew its dinn" (inna allāh yab'ath li-hādhihi al-umma 'alā ra's kull mi'a sana man yujaddid lahā dinahā) is offered by $A b \bar{u}$ $\mathrm{D} \bar{a} \cdot \bar{u} d$ at the beginning of Kitāb al-Malāhim. ${ }^{3}$ This part of the Sunan deals with events expected to take place immediately before the Hour (al-sāa $)$. The material dealing with this subject in the various collections of hadith includes some traditions indicating that the Hour was imminent; ${ }^{4}$ others enumerate various miraculous events the occurrence of which is necessary before the Hour can take place (ashrāt al-sāa $) .5$ These later traditions seem to mitigate the air of imminence surrounding the earlier ones. It is, of course, difficult to determine the context in which the mujaddid tradition originated. In a way it is similar to the traditions predicting the advent of the mahdi and seems to be a product of messianic expectations. It may also have been intended to offer a reason for the continued existence of the world despite the traditions asserting the imminence of the Hour and to allay the apprehensions aroused by them. 6 It is noteworthy that the concept of tajdid was originally unrelated to the revival of shari.a; this idea seems to be of much later origin. Shaykh Ahmad Sirhindi was given the title of 
Renewer of the Second Millennium (mujaddid-i alf-i thāni $)^{7}$ and the above mentioned tradition concerning tajdId was standardly quoted as the legitimization of this title. ${ }^{8}$ While this tradition clearly is the formal source from which the title was taken, in Sirhindi's thought the concept of tajdId is much more intimately connected with his awareness of the Millennium and its impact on the spiritual conditions of the world. The most succinct description of the millennial changes on the cosmological level is given in the Mabda. 이므. Sirhindi deals with the hierarchy of the "realities" (ḩagāig) and maintains that, contrary to views held by earlier șufis, hagigat-i ka ba is the highest hagiga. It is beyond the stage of attributes and defies any description. One stage lower is hagiqat-i qur.ānī, still lower haqĩqat-i muhammadi. This structure undergoes a fundamental transformation with the advent of the Millennium. SirhindI says: "I am about to say a wondrous thing that nobody has ever heard - . God acquainted and inspired me with it through his grace and generosity. A thousand odd years after the death of the Prophet ${ }^{9}$ a time is coming in which hagigat-i muhammadi will ascend from its position and unite with the position of haqigat-i ka ba. At this time bagiqat-i mubammadI receives the name hagIqat-i ahmadi and becomes 
the Manifestation of the Essence of God (mazhar-i dhāt-i ahad jalla sulțānuhu). Both blessed names (i.e., Muhammad and A hmad) unite with their meaning (musammā) (?). The former position of hagiqat-i muhammadi will remain vacant till 'Isā descends and enacts the shari'a of Muhammad. At that time haqiqat-i Isawi will ascend from its position and establish itself in the position of hagigat-i muhammadi that had remained vacant." 10 This cosmological development is reflected also on a lower level. Here it concerns the relationship between the Prophet Muhammad and his community. Mubammad had in the beginning two individuations (ta(ayyun): the bodily-human and the spiritual-angelic. These two individuations were symbolized by the loops of the two mims of his name. Since his death the human individuation has been gradually weakening while the spiritual one has been steadily gaining strength. Within a thousand years the human individuation disappeared altogether. Its symbol, the first mim of Muhammad, disappeared along with it and was replaced by an alif standing for divinity (ulūhiyyat). Muhammad came to be Ahmad. The disappearance of his human attributes facilitated his ascent, enabled him to reach the highest possible stage and to free himself from mundane attractions (kashākash-i ghayr o ghayriyyat); it had, 
however, an adverse impact on his community, ${ }^{11}$ which lost the lights of prophetic guidance emanating from Muhammad's human aspect. This is the reason why infidelity and innovation (bid'a) have gained the upper hand, while the lights of Islām and sunna have grown dim. Woe to the people, says Sirhindi, whose king does not tend to them, but rather focuses his entire attention on his beloved. 12

Sirhind $\bar{I}$ is thus in agreement with the view that the ideal period of Islamic history was the lifetime of the Prophet. He also agrees that it has been followed by a gradual decline. He does not, however, subscribe to the view that this decline is irreversible. As soon as it reached its lowest point with the complete disappearance of the human attributes of the Prophet and the absolute severance of his ties with his community, the trend was reversed and a new development set in. To justify his views on the reversal of the downward trend of Islamic history, Sirhindi makes use of a tradition originally associated with eschatological expectations. This tradition predicts the eventual return of Islām to its original condition. The Prophet is reported to have said: "Islām began as a stranger and it will return to what it was. How blessed are the strangers!" (al-islām bada'a gharīban wa ya ūd kamā 
bada'a fa-tūuba $1 i-\cdot 1$-ghurabā').$^{13}$ This tradition is found in several canonical collections of hadith. It describes there the times prior to the Hour, when Islām will grow weak and its followers become few. 14 SirhindI sees the situation of his own times in similar terms. Islām has become a rarity (islām... ghurbat paydā karda ast) and Muslims are strangers (gharīb) in an alien environment, in which no godly person (allāh gū ) will soon remain. 15 Happy is the man who manages to revive an abandoned sunna in these days. 16 There are indications that the Day of Judgment (giyāma), which was always expected to come at a time when people are wicked (tagūm al-sā'a alā shirār al-nās), is imminent.17 The mahdi has been heralded by the appearance of a comet. $^{18}$ In these days one has a special duty to promote the sunna and to extirpate even the "good innovation" (bid'a hasana), which might have been considered harmless in the more fortunate periods of Islamic history. 19 When compared with the ancient eschatological traditions, this passage makes it abundantly clear that eschatological speculations are in the background of Sirhindi's views of his times. His eschatology, however, does not expect the ultimate and of the world, but rather the arrest of the process of decline at its nadir by means of tajdid. 
Tajdid is mentioned in the Maktūbāt for the first time in a letter to Sirhindi's son, Muhammad Ṣādiq. Sirhindī vaguely refers in it to his times as being "full of darkness" and says that at such times during the pre-Islamic period a steadfast Prophet (payghambar-i ulū al-‘azm) $)^{20}$ was sent to the ancient communities (umam-i sābiga) in order to establish a new shari.a. 21 However, in the Islamic community, which is the best of all and whose Prophet is the seal of the Prophets, this is not possible. The Muslim 'ulama'. have therefore been awarded the same rank that had previously been given to the Prophets of Israel. 22 A mujaddid is chosen from them on the eve of every century, not to bring a new shari'a, but to revive the existing one. This is especially necessary after the passage of a thousand years: this is a time in which a steadfast Prophet was sent during the pre-Islamic period, as an "ordinary Prophet" could not have performed the task. When a period such as this occurs during the Islamic era, the situation requires a man of perfect

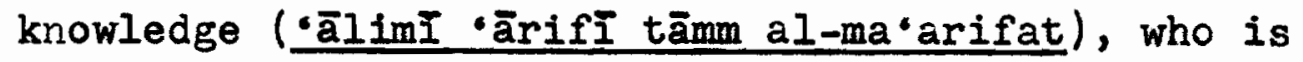
capable of fulfilling the task of the steadfast Prophet. Sirhindi sums up the discussion with a verse frequently quoted in the Maktūbāt: "If the bountiful Holy Spirit will help again, others will also (be able to) do things 
that Jesus had done" (fayź-i rūhul guds ar bāz madad farmāyad dIgarān ham bi-kunand ān čih masîhā mi-kard) ${ }^{2} 3$

The eschatological substratum of the concept of tajdid, and especially of tajdid-i alf, is evident also from the fact that Sirhindi considers the Millennium as the beginning of the "last" stage of Islamic history. The idea of the existence of such a last "stage" is derived from a tradition according to which the Prophet said: My community is like the rain: it is not known whether the beginning of it is better or the end" (mathal ummati ka-mathal al-mațar lā yudrā awwaluhu khayr aw àkhiruhu). 24 The comparison between the period of the Prophet and his companions and the Millennium is so close, that it is doubtful who is superior to whom. 25 The perfections (kamālāt) of Prophecy, which have been gradually disappearing since the death of Muhammad, will re-appear in persons who deserve this blessing because they are the Prophet's heirs and followers. 26 The person who possesses the se perfections is the mujaddid of the Millennium. His knowledge is derived from the lights of Prophecy which have regained their splendour. It is far beyond the knowledge of the jurists and the gnosis of the süfis. Whatever blessing the community receives during this period, it is through his mediation. 27 
It would thus seem evident that with the transformation of the Prophet into a purely spiritual being at the advent of the Millennium, the mujaddid is called upon to fulfil some of the Prophet's tasks with regard to his community. Though this is nowhere ecplicitly stated, his hagiga occupies in a sense the position of hagIgat-i mubammadi, which was left vacant between the Millennium and the eschatological advent of - Isā.

We have seen earlier that the ties of Muhammad with his community were completely severed with the advent of the Millennium. The cessation of his function as a guide of his people was accompanied also by profound changes in his spirituality. These were facilitated by the millennial mission of a "common believer" (fard-i ummat, fard az afrād-i ummat), whose function we shall presently describe.

The task of this "common believer" is connected according to Sirhindi with the spiritual relationship between IbrāhIm and Mubammad and with the sūfI concept of friendship (khilla). This friendship, which is the highest manifestation of love (hubb), is the principal force responsible for the creation of the world and its continued existence. 28 Originally it belonged to IbrāhIm, the Friend of Allāh (khalil allāh). ${ }^{29}$ Having 
reached this exalted stage, IbrāhIm was made the imām of all, 30 and even Muhammad was ordered to follow him. The Qur'ān says: "Follow the creed of Ibrāhim, a man of pure faith." (ittabi millat ibrāhIm hanifan). 31 And since it is not possible to reach the Essence of God

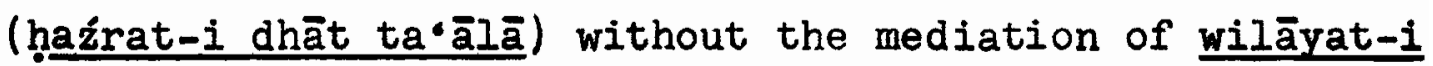
IbrāhImİ, the Prophet prayed: "O Lord, pray for Muhammad as you have prayed for IbrāhIm" (allahumma salli "alā muhammad kamā sallayta (alā ibrāhīm). 32

The "common believer"'s task is to facilitate the fulfilment of this supplication. To explain the way in which this is done, Sirhindi describes the relationship between the wilāya of IbrāhIm and that of Mubammad. He portrays the wilāyat-i ibrāhimi, - which is identical with the wilayat-i khillat, - as a circle whose centre and noblest part is the wilayyat-i mubarmadI. This being so, one cannot reach the wilāyat-i muhammadi without crossing the periphery of the circle and passing through all the stages of the wilāyat-i ibrāhīmì. This is the reason why Muhammad was ordered to "follow the milla of IbrāhĪm"; only through his mediation can be reach the centre of the circle which is the essence of his own wilāya and at the same time acquire all the perfections of the wilāyat-i ibrāhīmī. However, since Muhammad's wilāya is essentially part of the centre of 
the circle, it cannot enter its periphery without a mediator (mutawassit), who is related to both the centre and the periphery. This mediator is a member of his own community. With the advent of the Millennium he performs his task of mediation; Muhammad then returns him to the world to guard and preserve the community, while he himself holds tête-à-tête with the Beloved in the House of Celestial Seclusion (ān sarwar... a nn fard-rā az bi-rāyi hirāsat o muhāfazat-i ummat az ān-

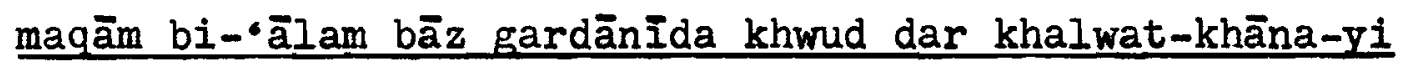
ghayb al-ghayb bā mahbūb khalwat dāshta) .33 It was this "common believer"'s mediation that enabled Muhammad to fulfil his millennium-old desire to reach the spiritual stage of Ibrāhİm and his own self-realization. The question whether the "common believer" and the mujaddid are identical clearly arises from our discussion so far. Both of them appear at the same time and have somewhat similar tasks in maintaining the link between the community and its source of inspiration. However, nowhere in the Maktūbāt are the two personalities treated as one or even mentioned together. Sirhindi formulated his ideas regarding them at different times. He deals with the concept of tajdid for the last time at the beginning of the second volume of the Maktūbāt. 34 The "common believer" is 
explicitly mentioned for the first time only towards the end of the third volume, ${ }^{35}$ though the idea was adumbrated earlier.36 This fact is significant for our evaluation of the development of Sirhindi's thought with regard to "orthodoxy": though the concept of tajdId-i alf is apparently Sirhind's innovation, there is sound classical basis for the concept of tajdid itself. Sirhindi can find no such basis for his later idea of the "common believer" and the severance of the link between Muhammad and his community. We, therefore, conclude that in questions related to the millennial changes Sirhindi does not move towards "orthodoxy" but rather away from it. It should be also pointed out that Sirhind I dealt with the ideas discussed here only in letters addressed to his sons and successors, Muhammad $\mathrm{Sa}$ 'Id and Muhammad Ma'ṣūm, and to one of his closest disciples, Muhammad Häshim Kishmi. 37 He was fully aware of the explosive nature of these ideas and was apprehensive of the opposition which they would arouse. 38 As we shall see later, his apprehension proved to be fully justified. 


\section{CHAPTER III}

\section{THE SELF-IMAGE OF A HMAD SIRHINDI}

We have seen that some of Sirhindi's disciples considered their master as the Renewer of the Second Millennium. We have also described Sirhindi's view of the Millennium as a crucial period in the spiritual history of the world. It is our intention now to study those parts of Sirhindi's writings from which we can gain insight into SirhindI's own view of his role in shaping the spiritual profile of his times. In particular, it would be instructive to know whether he considered himself as the mujaddid or as the "common believer" whose functions have been described in the previous chapter.

Sirhind describes his spiritual achievements in various places and has also a distinct view of his spiritual development. He gives an outline of this development in one of the earliest letters of the Maktūbāt. He wrote it after he heard that some people had been discussing his denial of the Unity of Being (wahdat al-wujūd, tawhId), in order to prevent the spread of any incorrect idea regarding his views. ${ }^{1}$ Since his very childhood, says SirhindI, he believed in 
the Unity of Being. Since this was also the belief of his father, he was able to gain intimate awareness of this world-view and enjoyed it immensely. Later he became associated with Muḥammad al-BāqI bi-'llāh who taught him the Naqshbandi path (țariga) and showed great interest in him. His awareness of the Unity of Being grew in intensity, and no subtlety of this theory remained unknown to him. He understood properly the minutest details of Ibn al-'Arabi's mystical insights, even those which are given - in Ibn al-'ArabI's view to the Seal of the Saints (khātam al-wilāya) only. His ecstasy and intoxication were so intense that in a letter to his teacher he wrote the following verses:

Alas! this shari'a is the religion of the blind, Unbelief and belief are the locks and face of that beautiful fairy,

Our religion is unbelief and the religion of the Christians, Unbelief and belief are the same in our path. This condition persisted for months and years. Then, suddenly, God caused his earlier insights which were based on the belief in the Unity of Being to disappear, ${ }^{2}$ and . Sirhindi learned that God can never be united with anything. His way parted with that of Ibn al-ArabI, and he came to see the correctness of the views of the People of the Sunna. ${ }^{3}$ 
This view of SirhindI's spiritual development has been rather uncritically accepted by most modern writers. 4 We have seen, however, that no literary evidence exists to corroborate Sirhindi's claim that he had passed through a period in which he did not see any difference between Isläm and infidelity. The first volume of the Maktūbāt contains twenty letters addressed to al-BāqI bi-’llāh, 5 but the ecstatic verses which SirhindI claims to have written to him do not appear in them. On the contrary, in these letters Sirhind $I$ vigorously affirms the complete compatibility of his mystical insights with the shari'a. Already in this early period he considers the outward meaning (zāhir) of the shari'a as the touchstone for the correctness of his şüfi experience 6 and finds himself in agreement with 'Alä. al-Dawla al-Simnāni $\overline{7}^{7}$ who was one of the earliest șufi critics of Ibn al-'Arabi's theory of the Unity of Being. 8 Sirhindi did not write any works supporting this theory before his meeting with al-BāqI bi-'llāh in 1008/1599-1600. Between this date and al-BāqI bi-'llāh's death in 1012/1603 - the period in which his letters to al-BāqI bi-•llāh must have been written - he was already convinced that the shari'a ought to be the touchstone of sūfī experience. It would thus seem evident that Sirhindi did not support the theory of the Unity of 
Being, as he interprets it here, for any substantial length of time, though he might have had moments in which this theory appealed to him. It is even less likely that he ever wrote the verses about the identity of Islām and infidelity at a time when he actually believed them to be true. It is probable that SirhindI wrote these verses only as a description of what he claimed to be his spiritual past. The editors of the Maktūbāt would have had no reason to exclude these verses from their original context if they did not find it necessary to expunge them from a later letter. Discovery of additional literary works by Sirhindi might correct this point, but, as the source material stands now, Sirhindi's claim to have passed through a stage of "intoxication" (sukr) seems to be intended to lend more authority to his "sobriety" (sahw). Pure sobriety is, according to him, the stage of "the common people who are like cattle" ('awāmm ka-’l-an'ām); 9 authoritative sobriety can be achieved only through its mingling with intoxication. 10

Like many sūfĩs before him, Sirhindī was deeply convinced that God had favoured him with spiritual insights that had not been previously given to anyone else. Mabda' o Ma'àd is particularly rich with assertions to this effect. Sirhindi feels that he has 
been given special understanding of the nature of the șūfi descent (nuzūl) to the world which was improperly understood before. ${ }^{11}$ In a vision of a celestial țawāf he outstrips his fellow pilgrims who turn out to be angels. $^{12}$ In a dream the Prophet gives him the rank of mujtahid in speculative theology $(\underline{\mathrm{kalam}})^{13}$ and writes for him an ijāza as a shaykh does for his khalifa. ${ }^{14}$ Sirhindi claims that no one has described the hierarchy of the bag $\bar{a} \cdot i q$ the way he did, and that no one has spoken about the transformation of this hierarchy with the advent of the Millennium. ${ }^{15}$ Finally, God told him: "I have forgiven you and those who are related to you, with mediation or without it, till the Day of Judgment." (ghafartu laka wa li-man tawassala bika bi-wāsița aw bighayr wāsita ilā yawm al-qiyāma) 16

As the years passed, Sirhindi's conviction that he had been given an extraordinary spiritual standing grew stronger and stronger. His increasing popularity among some of his disciples might have been one of the reasons for this development which reached its highest expression towards the end of the third volume of the Maktübāt. Sirhindi reached the conviction that several spiritual forces, combined in his personality, were responsible for his extraordinary spiritual achievements. His "intimacy" (wilāya) is a combination of the 
wilāyat-i muhammad $\overline{1}$ and wilāyat-i mūsawī. From this unique combination a new "reality" (hagiga) came into being. It resulted in magnificent, but secret, spiritual achievements; if he ventured to disclose any of them, or even hint at them, "the throat would be slit and the gullet severed" (gutica al-bul "um wa dhubiha albulqūm) .17

At abovt the same time SirhindI wrote a letter to a certain Șālih Kūlābī, who seems to have been one of his more trusted disciples. ${ }^{18}$ This letter contains the most eloquent, poetic and forceful expression of Sirhindi's claim to spiritual eminence and it is not surprising that it made him highly vulnerable to attacks by his opponents. It deserves to be translated in full:

"I am both the disciple of God (murĩd allāh) and His desire (murād allāh). The chain of my discipleship is connected ${ }^{19}$ with God without any mediation. My hand is a substitute for the hand of God. I am a disciple of Muhammad, connected with him through many intermediaries: in the Naqshbandi order there are twenty one intermediaries in between; in the Qādiri - twenty five and in the Cishti - twenty seven; but my relationship with God as a disciple is not subject to any mediation, as has already been related. Hence I am both the disciple of Muhammad the Messenger of God and 
his co-disciple (ham-pIra, i.e., we are both disciples of the same master: God). Though I am a parasite at the table of this wealth, sitting near the Prophet, yet I have not come uninvited; though I am a follower (tâbì), I am not without a share of genuineness (모밈); though I am a common believer (ummat), I am sharing in the wealth. This is not a sharing from which a claim of equality would arise; this would be infidelity (kufr). It is a sharing of a servant with the master. Until he called, I did not come to the table of this wealth and until he expressed his wish, I did not stretch my arm to partake in it. Though I am an Uwaysi, ${ }^{20}$ I have an Omnipresent and AlI-Seeing Instructor (murabbi-Vi hāáir o nāair). Though in the NaqshbandI order my instructor is :Abd al-BāqI, yet the one who has undertaken my instruction is the Everlasting one (a.l-bāaI). His glory is great and His munificence all-pervading. I have received my instruction through (His) grace and I have gone the way of the elect. My chain (of mystical instruction, silsila) is that of the Merciful (rahmani]), because I am a servant of the Merciful (abd al-rahmann). My lord is the Merciful One - great is His glory and all-pervading His munificence and my instructor is the Most Compassionate (arham al-rahimin). My path is the path of subhānI. I have gone the way of tanzIh; 
through Name and Attribute I am not seeking anything but the Essence. This subhānI is not the subhānI which was the creed of (Abu Yazīd) BisțāmI. The two do not have anything in common. That one (i.e., Bisțāmi's) has not gone out of the circle of the souls; this one (i.e., mine) is beyond the souls and the horizons. 21 That one is tashbih cloaked in tanzih; this one is tanzin untouched by even a grain of tashbih. The Most Compassionate did not use in my case anything but mu'addāt $^{22}$ as means of instruction; His grace was the only active factor in it. His great generosity, care and zeal for me prevented Him from allowing anyone else to take part in my instruction, but I have approached someone else in this matter. I am a divine disciple (murabbā-yi ilāhī) - great is His glory - and an elect of His boundless grace and generosity." 23

This was the self-image at which Sirhindi arrived at the end of his literary career. He was fully aware of the possibility that such statements, expressing ideas which were novel in his opinion, would arouse the opposition of his contemporaries. He expresses his apprehension particularly in connection with his views on the spiritual status of Ibrāhim and his relationship with Muhammad. After a detailed discussion of the subject, 24 Sirhindi says that although 
he did not arrive at these views by himself but rather through divine inspiration, people would resent them. The concepts which he uses, such as the "first individuation" (ta'ayyun-i awwal) were not known among the early Muslims (mutagaddimin), while the later generations (muta'akhkhirin) expressed different views regarding them. If anybody expresses nowadays an unusual idea, says Sirhindi, he will be cursed and humiliated by his contemporaries. In this particular case, Sirhindi expects to be accused of preferring IbrāhIn to Mubammad. Though he gave satisfactory answers to all the objections, he is not certain whether his opponents will be placated. There is no cure for stupidity, stubbornness and bigotry save divine intervention. 25

Regardless of whether Sirhindi's claim to originality in this field can be accepted, his views as summarized here will come as a surprise to anyone familiar with Sirhindi's image in modern literature. Sirhindi consciously advocates ideas which were, according to his own admission, unknown to the early generations of Muslims. He even chastises his contemporaries for their bigotry and traditionalism. We shall see later that with regard to the sunna Sirhindi expresses different ideas and vigorously objects to any 
innovation. It is therefore significant that in esoteric matters, expressed in letters to his trusted disciples, 26 Sirhindi considers himself as a thinker expounding ideas novel in Islamic thought.

We have still to answer the question whether Sirhindi considered himself as one of the persons invested with special spiritual powers in connection with the Millennium. Nowhere in the Maktūbāt does he identify himself explicitly with either the mujaddid or the "common believer". We have, however, a letter addressed to Muhammad Ma șūm in which Sirhindi describes his spiritual role in terms identical with those used later for the "common believer". He was created in order that wilāyat-i muhammadi acquire the tinge of wilāyat-i ibrāhīmi and the millennium-old desire of Muhammad be fulfilled. But even more important things were entrusted to him. He says: "I have not been brought (into this world) for the sake of șüfinstruction (piri) or discipleship (murĩdI). I was not created in order to perfect and guide the people. (My) work is different and so is (my) workshop. Whoever has the proper attitude in this matter will receive the divine bounty; others will not receive it. The work of perfecting and guidance (of the people) is, in comparison with that work (of mine), like a thing lying rejected on 
the road (ka'l-mațrūh fi al-țarig). The call (da'wa) of the Prophets is also of the same (low) standing when compared with their esoteric mission (mu'āmalāt-i bâtiniyya). Though the office of Prophecy came to an end, yet the perfect followers of the Prophets have a share in the perfections of Prophecy through (their) following and inheritance". 27

The tasks which Sirhindi sees here as his own correspond with those of the "common believer", but they also go beyond them. The "common believer" was sent to guard and preserve the community; Sirhindi here regards work of this kind with contempt. Similarly, he is contemptuous of the public activity of the Prophets which is worthless when compared with their much more important esoteric task. An exhaustive comparison of SirhindI's views on this matter with those of other thinkers is beyond the scope of the present study. One is, however, tempted to remark that Sirhindi's description of himself - or of the "common believer" - is reminiscent of Ibn al-'Arabi's theory of the Seal of the Saints (khātam al-awliy $\bar{a}^{0}$ ), who follows Muhammad as far as the shari'a is concerned, is his heir in this respect, but has also direct access to the genuine source of inspiration (al-wārith al-ākhidh 'an al-asl) ${ }^{28}$ Sirhindī's views on Prophecy as expressed here will be commented 
upon elsewhere; we ought, however, to point out that these striking views are expressed in a letter to Sirhindī's son and successor Muhammad $\mathrm{Ma}$ șūm. Thus, we have another instance in which Sirhindi deals with potentially explosive ideas only in letters to his closest associates.

Taking all this into consideration, we cannot accept the view according to which Sirhindi started his şūfĩ career with a period of intense intoxication which was in turn replaced by pure sobriety. We would be closer to the truth if we assumed that both elements were always present and that SirhindI determined the subject matter and the style of each letter according to the degree of preparation of each recipient. Sirhindi's self-image is also noteworthy for what it does not include: in his ecstatic utterances about himself Sirhindi does not mention the promotion of the shari'a as one of his tasks. One development is clearly discernible in the matter under discussion: Sirhindi's preoccupation with his own spiritual role in the world increased gradually and reached its highest point towards the end of his life. 


\section{CHAPTER IV}

\section{PROPHECY AND SAINTHOOD}

In our analysis of the concept of tajdid-i alf we have already seen the importance of Prophecy (nubuwwa) in SirhindI's thought. I It is our intention now to study the concept of Prophecy more systematically. It is fruitful to consider it together with Sainthood (wilāya), which had long been its sister concept in şūfĩ thought.

As we have seen earlier, ${ }^{2}$ SirhindI wrote his first work on Prophecy at the time of his association with Abu 'l-Fall, during the reign of Akbar. According to the mujaddidi tradition, Sirhind $\bar{I}$ was invited to $\mathrm{Abu}$ 'I-Faźl's court to assist him in his literary work. The two men were on friendly terms at that time, and $A b u$ ' $I$ Faźl had nothing but high praise for Sirhindi. ${ }^{3}$ During one of their discussions, however, Abu 'l-Faźl assailed the 'ulama'" and their concept of Prophecy and spoke disrespectfully of al-GhazālI; Sirhindi could not tolerate this, left the court in anger and did not return there until Abu 'l-Faźl apologized to him. 4 Sirhindi's discussions with Abu '1-Faźl in general and the above 
mentioned incident in particular apparently prompted Sirhindi to compile his Ithbāt al-Nubuwwa. The contents of this book have been very important for those modern historians, who regard Sirhindi as a champion of Islamic orthodoxy.

The book starts with a very gloomy description of Islām in India during the reign of Akbar. Sirhindi says in the preface that the people's belief in Prophecy is on the wane, and so is their compliance with the shari'a. "One of the tyrants of our age" (ba'd mutaghalliba zamāninā) - presumably Akbar himself - has tortured many ulama with the shari'a and their unflinching obedience to the Prophets. The situation is so bad that the name of Muhammad is not being mentioned at the royal court, and persons bearing it have adopted another name. The tyrant has forbidden the sacrifice of the cow, which is one of the most important symbols of Islām in India (min a.jall sha' $\bar{a} \cdot i r$ al-islām fí al-hind). He has demolished mosques and has honoured pagan temples; the customs of the infidels have been disseminated and their laws translated into Persian 5 with the aim of the obliteration of Isläm in view. Sirhindi began to investigate the reasons behind this situation and came to the conclusion that it had been brought about by "the remoteness of the prophetic 
period, the study of the science of philosophy and the books of the Indian sages" (bu+d al-"ahd min al-nubuwwa wa al-khawd fí 'ilm al-falsafa wa kutub hukamà' alhind) .6 He further mentions a debate with a person who was influenced by this material - presumably Abu 'lFazil - and who maintained that Prophecy was designed to promote public welfare (maslaba) and to restrain the common people from indulging in vice and strife, but had no connection with ultimate salvation (al-najāt alukhrawiyya). Abu 'l-Faźl found support for his position in the structure of al-Ghazāli's Ihyā' 'Ulūm al-Din: the fact that "Things Leading to Salvation" (munjiyāt) constitute a separate book and are not a part of the book on "Acts of Worship" ( $i b \bar{a} d a \bar{t}$ ) indicates that alGhazāli supported the Philosophers in thinking that Acts of Worship do not lead to salvation. Sirhindi rejects this argument by saying that the aim of Prophecy, indeed, is ultimate salvation. Al-GhazālI explicitly says that Acts of Worship do have saving power, and the structure of the Ihy $\bar{a}^{\circ}$ is a result only of the author's desire to deal separately with the outward (zāhir) and inward (bātin) aspects of religious observance. Sirhind $\bar{I}$ also rejects $A$ bu 'l-Faźl's contention that belief in the Prophet is not incumbent upon people living in the post-prophetic period because 
they have not seen his miracles and have not been convinced of the validity of his prophetic claim. The Qur'ān and the Traditions are sufficiently convincing in this respect. ${ }^{8}$

The rest of Ithbāt al-Nubuwwa is hardly of any interest, being, as we have seen, ${ }^{9}$ a reproduction of the classical ideas on Prophecy and its necessity, on the nature of the prophetic miracle (mu'jiza) and the Prophecy of Muhammad, and on the inability of the intellect to arrive at certain truths without prophetic help. The book bears precious little relationship to the main body of Sirhindi's views on the subject, which will be our present concern.

The frame of reference in which Prophecy is discussed in the Maktūbāt is a șüfi one. While in Ithbāt al-Nubuwwa the Prophet is a man to whom God said "I am sending to a certain people" or ". . . to all people" and who does not need any additional qualifications to fulfil his task, 10 in the Maktūbāt Prophecy is viewed as an advanced stage (magām) in the spiritual journey of the șufi towards perfection. The approach of the mutakallimūn to the question of Prophecy, fully adopted by SirhindI in Ithbāt al-Nubuwwa, has all but disappeared in the Maktūbāt. Its place has been taken by discussions about the spiritual nature of the prophetic experience, 
its connection with wilaya and its relationship with God (hagq) and men (khalg) respectively. The transformation of Sirhindi's views on Prophecy between Ithbāt al-Nubuwwa, which had been written before he joined the Naqshbandiyya, and the Maktūbāt, which were written afterwards, is only one sign of the deep change in religious outlook which Sirhindi underwent as a result of his initiation into the Naqshbandi order. He no longer simply reiterates the views of the mutakallimūn on Prophecy; he approaches it from a characteristically şūfĩ view-point.

During his şūfĩ period, SirhindI describes the spiritual achievements of Prophecy and Sainthood in different ways. Two types of relationship between them are discernible in the Maktūbāt. Prophecy and Sainthood are sometimes described as two parallel ways leading to different degrees of divine awareness. In other cases Prophecy appears to be the culmination of the spiritual journey of the Saint.

In descriptions of the first type, the way of Prophecy leads directly and without any mediation to the genuine Source (ass. 1 al-assll). This was originally the way of the Prophets and of their companions; very few of their followers in the post-prophetic period are allowed to embark upon it. The way of Sainthood, on the other 
hand, is the way of eminent șufis, such as the aqtāab,

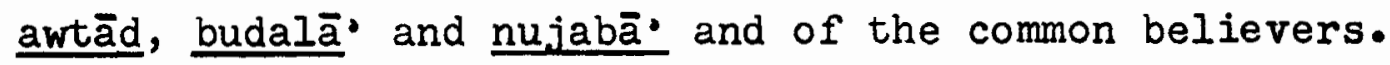
This way does involve mediation (tawassut, haylūla) between the șuffi and his God. The leader of those using this way is "Ali. He had held this position even in his pre-existence, before he came into this world at the time of Muhammad. Every participant in the journey through the way of Sainthood receives the divine blessing (fayz) through 'Ali's mediation. After his death, the task of mediation was given to Hasan and Husayn and, later, to the twelve imäms and to 'Abd alQādir al-Jīlāni. 11

Let us turn now to descriptions of the second type.

The spiritual journey culminating in the acquisition of prophetic perfections consists, in Sirhindi's experience, of four stages. In the first stage, called fanā' and "Journey towards God" (sayr ilā allāh), the şūfi abandons the realm of the possible (mumkināt) and reaches the knowledge of God in the realm of the necessary (wājib). The second stage, called bagā' and "Journey in God" (sayr fī allāh), brings the şüfi to spiritual heights that defy any verbal description. During the third stage, "Journey towards God through God" (sayr ilā allāh bi-’llāh), the 
şüf $\bar{z}$ begins to descend from the pinnacle of his experience into the realm of the possible. The fourth stage is the "Journey in Things" (sayr dar ashyä.), during which the şūfi acquires again the knowledge of the concrete world which escaped him during his ascent. The first two stages of the journey are connected with Sainthood; the third and the fourth enable the șüfi to reach the "Stage of the Call" (maqām-i da wat), which properly belongs to the Prophets, but can be shared also by their perfect followers. ${ }^{12}$ Not every sūfi reaches the stage of the prophetic descent, but there is a close affinity between the Prophets and the șifis whose spiritual achievements are sufficient to permit it. Prophecy is thus better (afdal) than Sainthood, but it also is, paradoxically, the result of descent from the summit of spiritual achievement.

In other descriptions of the spiritual "stages" (maqāmāt), Prophecy ranks above wiliāya, shahāda and siddiqiyya. It is interesting to note that Sirhindi here reduces the difference between the Prophet and the siddig to a minimum. He affirms that there is no difference between the kinds of knowledge (ilm) possessed by these two persons. The only differences between them lies in the way in which they communicate with the source of knowledge. The siddig receives his 
knowledge through inspiration (ilhām) which is prone to error, while the Prophet receives the same knowledge through revelation brought down by an infallible angel (waby). Thus, though the Prophet receives his revelation in an error-proof way, there is no difference between himself and the siddig in so far as the substance of the knowledge is concerned. 13

These descriptions of the relationship between Prophecy and Sainthood differ from each other, but they demonstrate the close affinity of the two concepts in Sirhindi's view. Both the Prophets and the most successful şüfis are allowed direct access to the ultimate source of religious inspiration. There are, however, also differences between them. The Prophet is marked by his sobriety (sahw); the Saint by his intoxication ( $\underline{\text { sukr }}$ ). 14 The Saint and the Prophet do not always have the same ability to focus their attention upon the objective of their journey. The difference between them comes to the fore especially during the stage of descent. The Prophet, who has fully experienced the Ultimate Reality (hagg) at the peak of his ascent, can now concentrate entirely upon his mission to the people (da'wat-i khalq). On the other hand, the Saint, whose ascent failed to give him the ultimate experience of Reality, tries to compensate himself for this failure 
during the descent. He directs only his outward (zāhir) attention towards the people, while his inner (bäțin) self makes abortive attempts to catch another glimpse of the Ultimate Reality. His energies are thus dissipated, and his experience cannot be completely satisfactory. 15

In Mabda' o Ma'ād Sirhindī considers his understanding of the perfect, single-minded spiritual descent (nuzūl) as one of his original contributions to şüfĩ thought. His predecessors held, according to him, that the perfect descent is that during which the șüfi is mindful of both hagg and khalg; ${ }^{16}$ their view was basically different from his own conception of the single-minded descent. In a later letter in the Maktūbāt, however, Sirhindī describes the prophetic descent in a way that renders meaningless any distinction between the two views regarding it. After describing the single-minded concentration of the descending Prophet on his mission to the people he says: ". . the true understanding of this stage is that turning towards the people is the same as turning towards God. 'Wherever you turn - there is the face of God. 17 This does not mean, however, that the possible is identical with the necessary .. ." (wa tahgia-i In maqām ān ast kih tawajjuh bi-khalg ayn-i tawajjuh bi-hagq ast faaynamā tuwall $\bar{u}$ fa-thamma wajh allāh nah bi-In ma'nā 
(kih) mumkin ayn-i wäjib ast ... . $)^{18}$ This apparent change in Sirhindi's views on the matter has also a wider significance which will be considered later. 19

It is on the basis of the above description that Sirhindi reaches his conclusions concerning the superiority of Prophecy to Sainthood. Those who preferred Sainthood to Prophecy, says Sirhindi, based their view on the faulty assumption that Prophecy is concerned exclusively with people (khalg), and therefore cannot be of the same value as Sainthood, which aspires to experience the Ultimate Reality (haqq). Such people believe Sainthood to be inherently connected with the ascent ( $u r \bar{u}, j)$, while Prophecy comes into the picture only during the descent (nuzūl). Once it is understood, however, that both Prophecy and Sainthood participate in both phases of the spiritual journey, and that the achievements of Prophecy in both are superior to those of Sainthood, there can be no doubt as to the over-all superiority of Prophecy. 20 It is possible, however, that in some partial aspect a Saint may be superior to a Prophet. His position would then be somewhat similar to that of the martyrs in the holy wars of Islām (shuhada') who, in some sense, rank higher than the Prophets. Since this partial superiority is a result of the Saint's scrupulous observance of the prophetic 
commands, it entails no disrespect towards the Prophet. On the contrary, the reward for the Saint's spiritual achievements reverts to the Prophet, in accordance with the badith: "Whoever institutes a praiseworthy sunna, will receive his own reward and the reward of those who follow it" (man sanna sunna hasana fa-lahu ajruhā wa ajr man 'amila bihā). 21 Sirhindi therefore sees no harm in the words of Ibn al-"Arabi who said that "the Seal of the Prophets learns from the Seal of Sainthood". The commentators of Fușūs al-Hikam, says Sirhindi, needlessly felt compelled to explain his words artificially by saying: "The Seal of the Saints is the treasurer (khazina dār) of the Seal of Prophecy. If the king takes something from his treasury, there is no harm." 22

To what extent can persons living in the postprophetic period hope to acquire the spiritual blessings of Prophecy?

It is one of the frequently recurrent themes in the Maktūbāt that the accomplished followers of the Prophets can acquire a share in the prophetic perfections "through following and inheritance" (bi-taba'iyyato wiräthat), though Prophecy as such came to an end with the completion of Muhammad's mission. Even in the postprophetic period there are persons, though extremely few in number, who are allowed to approach God by way of 
Prophecy. All those who traverse the prophetic way reach their objective directly; none of them has to serve as a mediator for the others. ${ }^{23}$ These are neither the People of the Left (assāb al-shimāl), who are covered by the veils of darkness, nor the People of the Right (ashbāb al-yamin), who are covered by the veils of light; these are the First-comers (säbigān) who have freed themselves from all veils. Though no person can reach the rank of a Prophet any longer, these people have been given all the prophetic perfections. "In reality", says Sirhindi, "I myself am a member of the group of the Companions and I share the perfections of the Prophets" (wa fi al-hagĩga in shakhs niz az zumra-yi aşbāb ast wa mulhag bi-kamālāt-1 anbiyāo) ${ }^{24}$

Thus, though Sirhindi vigorously upholds the Islamic doctrine according to which Muhammad was the last of the Prophets, Prophecy is, in a sense, a continuing reality. The prophetic perfections, which are said to be continuously present in the chosen few followers of the Prophets, emanate from Prophecy the conception of which is deeply influenced by șüf ideas. We have seen that in the Maktūbāt Sirhindī has all but abandoned the approach of the mutakallimun to the question of Prophecy. The persons endowed with prophetic qualities discussed in the Maktūbāt are not Prophets who 
have been formally sent by God to warn a community or to bring a new shari'a. They do not perform miracles in order to convince the people to whom they have been sent of the validity of their claim to Prophecy. They cannot even be called Prophets in the proper sense of the word. Yet they do retain the cardinal spiritual privilege enjoyed by the Prophets of old: they are allowed direct access to the divine source of inspiration and are in no need of prophetic mediation like ordinary believers. We have seen that Sirhindi himself claimed to have attained this special status. ${ }^{25}$ We have also seen that the lights of Prophecy and the Prophetic perfections have regained their splendour with the advent of the Millennium. The accomplished followers of the Prophets, who live in the millennial period and possess the prophetic perfections "through following and inheritance", are barely distinguishable from their predecessors of the prophetic period in whom these perfections were originally (bi-・l-așāla) invested. 26 The frequency with which Sirhindi speaks of persons possessing the prophetic perfections is indicative of the importance that he attaches to the matter. The problem, indeed, is important: in what way does the Muslim community maintain its contact with the Divine after Prophecy has come to an end? Many Muslim thinkers 
have been confronted with this religiously crucial question, and various answers have been given. Probably the most "orthodox" answer to the question has been given in the saying which states that the 'ulama'. are the heirs of the Prophets (al- 'ulamā' warathat al-anbiyā'). The most elaborate answer has been given by the ShI'Is, whose imāma and wilāya continue to perform those prophetic functions which are the most important in shi'I thinking. 27 Sirhindi's own answer to the question faithfully reflects his sunni patterns of thought. Instead of the imāms of the ShI'Is he speaks of the Companions

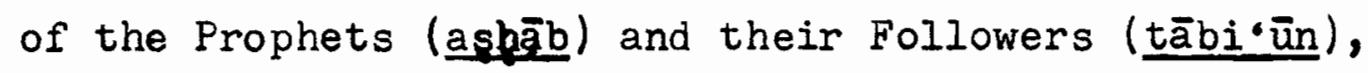
who were given a share of the prophetic qualities of their leader. These qualities were latter transferred to those who faithfully follow the sunna of the Prophets. It seems to us that in SirhindI's thought the concept of Companionship is being extended in time and that, in a sense, every age has its own Companions and Followers. This is the background against which SirhindI can claim to be "a member of the group of the Companions" and against which he can repeatedly assert that persons possessing prophetic perfections never cease to exist. Thus the Muslim community is able to retain its contact with the Divine, despite the fact that Prophecy as such came to an end with the completion of Muhammad's mission. 


\section{CHAPTER V}

\section{SIRHINDI'S VIEW OF THE ISLAMIC TRADITION: I}

It is our intention to study in the two following chapters SirhindI's views with regard to the various components of the Islamic tradition. We shall analyse his views on major Islamic concepts, movements and personalities. The analysis will demonstrate that his views on virtually all matters are deeply influenced by his comprehensive şūfĩ outlook.

1. Sunna, Sharía and Tarĩga.

Modern writers have repeatedly stressed that in Sirhindi's view sunna and shari'a are the most important components of Islamic culture. In a sense this is true, and there are many statements to this effect in the Maktūbāt, in Mabda. o Ma's̄d and in the various accounts of Sirhindi's thought written by his disciples. On the Day of Resurrection, says SirhindI, people will be questioned about their adherence to the

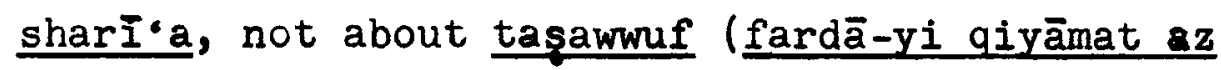
shari'at khwāhand pursīd az taşawwuf na-khwāhand pursid)..$^{I}$ He urges his disciples to read books on figh and affirms that șūfi experience is inferior to the 
shari'a and not vice versa, because shari'a is based on incontrovertible proof, while șūfi experience is a result of fallible speculation only (ahbāl tābi'-i shari'at ast na shari'at tābi'-i ahwāl kih shari'at gat'i ast wa ahwāl zanni]) ${ }^{2}$ One of his disciples recalls that when he was overwhelmed by hạal, Sirhindi used to tell him: "Go to study your lesson, because an ignorant sūfi is the fool of Satan!" (sabag bi-khwān kih sūfī-yi jāhil maskhara-yi shayțān ast).$^{3}$ Any șūfi experience that is rejected by the sharI'a is heresy (kull hagIqa raddathu [sic] al-shari'a fa-huwa zandaqa wa ilhād) , 4 says Sirhindi, and the Maktūbāt contain countless exhortations to follow the sunna and comply with the shari'a. These and many other statements in a similar vein are sufficient to show that in Sirhindi's view compliance with the shari'a is essential. However, in order fully to understand the significance of this view, we must elucidate the concept of shari'a in Sirhindi's thought. Only in this way shall we be able to see Sirhindi's statements regarding it in the proper perspective. It is not sufficient simply to state that Sirhindi upheld the shari'a, as his modern interpreters have asserted; one must describe Sirhindi's view of the shari'a in order that such a statement be meaningful. Sirhindi deals with the concept of shari'a in 
two different contexts. Occasionally he considers it from the point of view of a jurist and gives his opinion on certain points of law. In the vast majority of cases, however, he discusses the shari'a in terms of șūfi thought, analyses its outward (zâahir) and inner (bāţin) aspects and describes its relationship with such concepts as tariga and hagiga.

Discussions of juridical problems are extremely rare in the Maktūbāt and in the other works by Sirhindi. It is noteworthy that while Sirhindi never wearies of describing the minutest details of şü experience, his exhortations to comply with the shari'a remain general to an extreme. We rarely find in the Maktūbāt a warning against a concrete infraction of Islamic law common in Sirhindi's time or a reference to a specific legal question. Let us deal briefly with these rare cases before turning to the main body of Sirhindi's thought relative to the question of shari'a

Epistle 191 of the first volume of the Maktūbāt is addressed to 'Abd al-RaḥIm Khān-i Khānān, a high official of the Mughul court. ${ }^{5}$ Its purpose is to convince the recipient that Islamic law does not impose difficult duties on the believer. The shari'a is easy to comply with. For instance, only seventeen daily rak'as were prescribed, and these can be performed in 


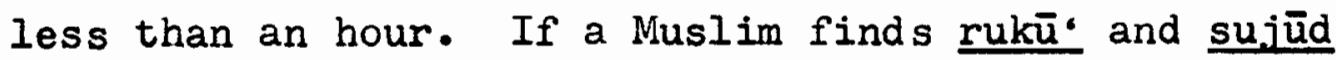
to be difficult, he can comply with the law by performing them symbolically. If he cannot perform the ablution with water, he can do so with sand. Only one fortieth of property was fixed as zakāt, and even then not all kinds of property are taxable. Pilgrimage (haji) has to be performed only once in a lifetime and only if transportation and supplies are available and roads are safe. Generally speaking, God has widened the sphere of the permitted actions (mubāhāt). He has permitted every man to wed four wives and to have an unlimited number of concubines; moreover, He has provided for exchanging wives at will by permitting divorce (čahār zan bi-nikāh wa az sarārī har qadr kih bi-khwāhad mubāh farmūdah wa țalāqrā wasila-yi tabdīl-i nisā' gardānīdah). Sirhindi continues in the same vein while dealing with matters such as clothing and food and concludes, saying that if anyone finds the shari'a onerous, he doubtlessly suffers from an affliction of the heart (marazi-i galbi).$^{6}$ These views on legal matters, and especially those concerning divorce, are reminiscent of the legal stratagems (hiyal) evolved by some fugahä. in order to circumvent certain legal precepts. It should be kept in mind that this letter is addressed to a government official, with whom Sirhindi corresponded over a lengthy 
period of time in an attempt to influence his thinking. The emphasis on the permissive nature of the shari'a, which is not the usual attitude adopted by Sirhindi, 8 is designed to make Abd al-Rahim more receptive to Sirhindi's ideas on the necessity of complying with the law as fully as possible.

Sirhindi's approach to the question of innovation (bid'a) is also relevant to the description of the non-șufi portions of his views on Islamic law. Here again we are faced with scarcity of specific material on the subject, though general exhortations to follow sunna and avoid innovation are abundant. Sirhind I very rarely speaks of innovations which are peculiar to the Muslims of India as a result of their life in the midst of a Hindu people. 9 In most cases he deals with the problem on the theoretical level, adducing random examples only to prove a general point. In several places in the Maktūbāt he launches vigorous attacks against the distinction between good innovation (bid'a hasana) and bad innovation (bid'a sayyi'a), 10 asserting that either of them is certain to do away with a sunna and should, therefore, be scrupulously avoided. The innovations which Sirhindi condemns in this context are rather trivial and none of them arises from Hindū influence. It has been said, for example, 
that the use of the turban as a part of the shroud is a good innovation; it is clear, however, that this contravenes the sunna by using an additional piece of cloth beyond the three prescribed ones. To place the turbansash on the left side has also been considered as a good innovation, though it is evidently inconsistent with the sunna, which demands that the sash be allowed to hang between the shoulders. The opinion of those 'ulama'- who maintain that it is laudable to express the prayer-intention (niyyat-i namāz) aloud, though the Prophet and his companions never did it in this manner, is also unacceptable. In case this recommendation is followed, most people are satisfied with the words and are not concerned with the intention of the heart (irāda-yi qalb); a sunna is thus abrogated. Therefore, all innovations are bad and ought to be shunned. ${ }^{11}$ The Qur'ān says: "Today I have perfected your religion for you and bestowed upon you all my favour, and I have approved Islām as your religion." Islām is thus perfect and does not require any modifications or additions. 12 Such is Sirhindi's approach to the question when he is writing on his own initiative and can freely choose the examples to support his unequivocal rejection of any innovation. But not always is he given this freedom of choice. In the Maktūbāt there are a few 
cases in which Sirhind $\bar{I}$ is asked about specific matters relating to the question of innovations. One of his closest disciples, Muhammad Hāshim, pointedly inquires whether the Prophet and his companions knew about sulūk and jadhba which are frequently mentioned in Sirhindi's works; if they did, what expressions did they use to describe them? if not, can these concepts be considered as good innovations? The question is clearly rhetorical, and after trying to explain it away by saying that the companions were in no need of jadhba and sulük because of their proximity to the Prophet, Sirhindi is compelled to admit that "the expressions fan $\bar{a}^{\prime}$, baq $\bar{a}^{\prime}$, jadhba and sulūk were not used in the time of the Prophet and were invented by the şūfīs" (pas "ibārat-i fanā' O baqā' o jadhba o sulūk muhdath bāshad wa az mukhtara'āt-i mashāyikh). 13

In another case, one of the disciples asks Sirhindi why he disallows the performance of dhikr aloud (dhikr-i jahr) while condoning other customs unknown at the time of the Prophet, such as the wearing of farjī, shāl and sarāwīl ${ }^{14}$ Sirhind's reply is that the Prophet's actions are of two kinds: those connected with worship ( custom ( urfo a $\bar{a} d a)$. If something is found to be inconsistent with the Prophet's actions of the latter 
kind, it must not be considered a "blameworthy innovation" (bid-at-i munkar), because it "has no connection with religion" (bidin ta"alluq na-dārad). It is only a matter of custom that may change with time and place. ${ }^{15}$ It may also be pointed out here that Sirhind imself occasionally engaged in practices questionable from the point of view of "pure" Islām, such as "giving alms to the spirits of the dead" (tașadciug bi-arwāh-i mawtāa). He describes in details the manner in which this should be done and demands that whenever alms are given to the spirit of a deceased a separate gift be given to the Prophet.15a

The main part of Sirhindi's thought relating to the question of shari'a is deeply influenced by his șüf outlook. Sirhind $\bar{I}$ is not interested in the details of the shari'a, but rather strives to incorporate it, as a major Islamic concept, in his comprehensive șüfī world-view. It is therefore to be expected that he speaks of the shari'a in a characteristically sūfí way. Sharīa consists, in his view, of two parts: form (șüra) and essence (haqIqa). In other words, it has an outward (zāhir) aspect and an inner (bat.in) aspect. The outward form of the shari'a involves compliance with the Guraanic commandments despite the struggle which one has to wage at this stage with his evil-bidding soul (nafs-i ammāra). It is only God's mercy that enables persons who do not transcend this rather low stage to enter Paradise. Paradise and its pleasures, how- 
ever, also have form and essence; those who in this world reach the stage of formal belief (șūrat-i Imān) only, will not enjoy Paradise in the same way as the people of the essence (arbāb-i hagiqa). The essence of shari'a (hadiqat-i shari'at) can be arrived at by properly understanding the ambiguous verses of the ur'ān (mutashäbihāt). This understanding can bring about the perfections of Prophecy (kamālāt-i nubuwrat), while the form of shari'a is capable of producing the perfections of Sainthood (kamālāt-i wilāyat) only. 16

Sirhind I deals with the two aspects of the shari'a also in connection with the spiritual ascent of the șufi. Its form is capable of rising only within the sphere of the possible (silsilayi mumkināt); during the spiritual ascent through the stages of the necessary (marātib-i wujüb) it must combine with the essence. If there is further ascent above this sphere, the form and the essence separate again, and the şüf can reach the water of Life (āb-i hayāt). Ihis is a stage which has no connection whatsoever with the world. The șüi finds himself here outside the circle of the shari'a. He is, however, "protected" from sin (mahfüz) 17 and does not neglect any part of the shari'a. Those who are allowed to reach this supreme stage are very few. ivany more șüfis reach only its shadow, imagine that they have gone outside the circle of the shari'a and end up with heresy. Only the perfect ones are capable of nain- 
taining the shari.a in its entirety at this stage. ${ }^{18}$

Every member of the community, even the șūfĩ who is allowed to reach the highest stage of spiritual progress, is thus obliged to comply with the shari.a. 19 The proper, "essential" (hagĩg) compliance depends upon the spiritual advancement of the believer; only those who have subjugated their evil-bidding souls are capable of achieving it. 'i'hough God is merciful enough to accept formal belief and practice as sufficient for the atiainment of "formal" salvation, șufi discipline is necessary in order to achieve a higher stage. This discipline, called in the Maktūoāt mostly țariqa and sulūk, confirms the shari'a and makes its knowledge more detailed and nore certain. Shari’a and țaríga are, on the one hand, two expressions of the same reality; ${ }^{20}$ on the other hand, țariga is a servant of the sharía whose service is essnetial for making the sharica complete. 21 The relationship between shari.a and țariga is parallel to that between Prophecy and sainthood: shari'a is superior to țariga in the same way as Prophecy is superior to Sainthood. At the same time, shari'a can no more dispense with teriga, than Prophecy with Sainthood.22 Sirhindi's peculiar approach to the question of shari'a is evident also from other statements scattered

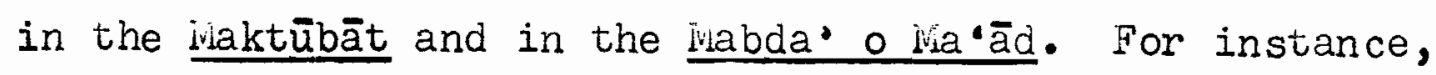


he defines sulūk as being "compliance with the sharía: repentance, asceticism and the like" (sulūk kih "ibärat az ityān-i sharī'at ast az tawba wa zuhd wa ghayruhumāa) ${ }^{23}$ His uncompromising insistence on compliance with the shari'a and his intransigent hatred for those who oppose it are explained also in șūfī terms: an ardent lover can brook no compromise with his rivals (dar mahabbat mudāhanat gunjāyish nadārad muhibb dīwāna-yi maḩoūb ast tāb-i mukhālafat nadārad bi-mukhālifān-i mahbūb bi-hَ̄ēe wajh āshti nami-numāyad) ${ }^{24}$ Another way of placing the shari'a squarely within the șîfi world-view is to say that one cannot reach his real objective without "annihilating hinself" entirely in the shari'a (tā tamām-i khwud-rāa dar sharī'at gum na-sāzad wa bi-imtithāl-i awāmir o intihā'-i nawāhī mutahalli na-gardad būy az in dawlat bi-mashāmm-i jān-i ù na-rasad). 25 The Persian khwud-rā gum sākhtan is a translation of the Arabic șăfi term fanā', and Sirhind $\bar{i}$ thus speaks of al-fana shari'a. Perhaps the most striking example of the impact of șüfi ideas on Sirhindi's views of the shari'a is contained in his few remarks concerning the Islamic schools of law (madhāhib). In most legal matters in which differences of opinion exist between the Shāfi' $\bar{I}$ and the Hanafi schools, says Sirhindi, the outward and formal aspect is according to the Shäi'i school, while the 
inner, "essential" aspect is in accordance with the Hanafī school (wa akthar-i masā'il-i khilāfī miyān-i shāfi' $\bar{i}^{26}$ az in qabil ast kih zāhir o sūrat murajilih bijānib-i shāfi ‘ $I$ ast wa bātin o haqĩqat mu ayyid-i madhhab-i hanafi) .27 In another context the perfections of Sainthood are said to correspond to the Shāfi'I law, while those of Prophecy are considered related to the Ḥanafī law (. . kamālāt-i wilēyat-rā muwāfaqat bifigh-i shāfi'I ast wa kamālāt-i nubuwwat-rā munāsabat bìfigh-i hanafi) .28 The tradition according to which Abu Hanifa laid particular stress on the idea of sunna and used scriptural rather than rational proofs ${ }^{29}$ is apparently behind Sirhindi's preference of the Hanafi school. The preponderance of this school in Transoxania where the Naqshbandi order came into being is another probable reason for his view. Questions of legal practice, however, hardly play any role in Sirhindi's adoption of the Hanafi school.

What are Sirhind''s views regarding the guardians of the shari'a, the ulamā.? 30 The classification of the 'ulama's offered by Sirhindi faithfully reflects his views of the shari'a as described above. The form of the shari'a, which according to Sirhindi is contained in the unequivocal verses of the Qur.ān (muhkamāt), 31 is the domain of the 
"superficial" 'ulamā' (ulamā'-i zawāhir). They are captivated by the form, deny the existence of any essence in it, and are guided solely by books on figh, such as the Hidāya ${ }^{32}$ and BizūdI (?). The essence of the shari'a, on the other hand, is dealt with by the profound 'ulamā' (ulamā'-i rāsikhān). It is found in the ambiguous verses of the Qur'ān (mutashābihāt), which are the kernel and heart of the Book. The unequivocal verses, though called ummahāt-i kitāb, are nothing but means to reach the substance (nat $\bar{a} \cdot i j$ ) contained in the ambiguous ones. The profound 'ulama'. understand the dual nature of the shari'a, insist on attaining both its form and essence, but concede that the form is sufficient for a person to be a Muslim. Between the two groups of the 'ulamā' are the Saints (awliya'-i khudā). They are captivated by the essence, but do not consider it the essence of the shari'a. In their view the Shari'a is a mere husk without a kernel; still, they do not refrain from observing it scrupulously. 33

We may say in conclusion, that in his discussion of the sharía, Sirhindi clearly values its inner, "essential" aspects above its outward and formal ones. This preference results in according the highest status to the ambiguous verses of the Qur'ān in which the essence is thought to be contained. Sirhindi maintains 
this view despite the fact that according to the Qur'ān itself only "those in whose hearts there is a deviation follow the ambiguous (verses) desiring dissension . . 134 At the same time he maintains, that the outward form of the shari'a cannot be dispensed with, since, philosophically speaking, the form can never be separated from the essence, and nobody can reach the essence while disregarding the form. The concept of shari'a is thus fully incorporated into the șüfī world-view. The characteristic şūfi dichotomy of form and essence is thoroughly applied to it. Those whose compliance with the shari'a is merely formal are rather condescendingly accepted into the Muslim community; their inferiority to those who reach the essence is, however, made abundantly clear. That the 'ulama'" who reached the highest stage of inner understanding are called 'ulamā'-i rāsikhān is also noteworthy: Sirhind $\bar{I}$ here seems to use the term that is most acceptable in the sunni world-view in order to express a șüfi, or even a shī‘i, notion. 2. The concepts of Islām and infidelity (kufr). As in the case with numerous other subjects, Sirhindi deals with the concepts of Islām and infidelity on two different levels. On the one hand, he puts forward his views regarding the status of infidels in a Muslim society and, specifically, the treatment that ought to 
be meted out to the Hind $\bar{u}$ inhabitants of the Mughul empire. He makes his views on this subject clear mainly in letters to officials of the Mughul government, and we shall discuss them in due course. On the other hand, he discusses infidelity and related concepts in a sūfī frame of reference. This part of Sirhindi's views on the matter will be our present concern.

Islām and infidelity are normally determined by shar' $\bar{I}$ criteria. But at the same time, says Sirhind $\bar{I}$, there are also Islām and infidelity which constitute stages in the spiritual progress of the șufi along the Path (țariga). The șūfĩ infidelity (kufr-i țarīgat) comes into being in the stage of unity (maqām-i jam*) ${ }^{35}$ The șüfi does not at this stage see anything except the beauty of the Beloved. The common distinctions between good and bad, truth and falsehood, are meaningless to him; he considers them only as shadows of the allembracing unity. He, therefore, can be at peace with everyone and affirm that all are following the straight path. Occasionally he even affirms the identity of God (hagq) and the creation (khalq). This was the spiritual stage of al-Hallāj when he said: "I have denied the religion of God; infidelity is incumbent upon me, but is repulsive to the Muslims" (kafartu bi-dini 'llāhi wa -1-kufru wājibun / Ladayya wa (inda 'I-muslimina gabīhu). 36 
The infidel of the țarIqa, unlike the infidel of the shari'a, does not deserve punishment. He has reached the stage of infidelity as a result of being overwhelmed by the love of God that has caused him to forget everything else. The touchstone of his sincerity is his compliance with the shari'a. Al-Hallāj every night performed 500 rak'as in his prison and refused to eat the food given to him by his captors for fear that it might have been procured in an unlawful manner. The infidel of the shari'a is, on the other hand, dominated by ignorance (jahl), rebels against God, and will not be spared his punishment.

Isläm in the shar'I sense is, of course, a higher stage than shar'i infidelity. The same applies to the şüi Islām (islām-i tariqgat), which is higher than the șüfi infidelity and is attained at the stage of separation following unity (farg ba'd al-jam $) .37$ The distinctions between good and bad, truth and falsehood, regain their validity at this stage. The two kinds of Islām are related to each other; moreover, when Isläm in the shar'i sense reaches its perfection and attains the essence of the shari'a, it unites with the şüfi Islām. Sirhindi summarizes his analysis so far by an assessment of the relative value of the spiritual stages discussed here: "The stage of the șüf infidelity is higher than 
the Isläm of the form of the shari'a, though it is lower and baser than the Islām of the essence of the shari‘a" (martaba-yi kufr-i tarīgat az islām-i sūrat-i shari'at buland-tar ast har cand nisbat bi-islām-i haqIqat-i shari'at past o adwan ast). 38

SirhindI's distinction between the various kinds of Islām is related to the distinction he makes between the various parts of the Muslim community. In his view there is a fundamental difference between the common people ('awāmm), whose Islām is merely formal and never reaches beyond the simple observance of the sharīa, and the spiritual élite (khawāss), whose true, real Islām emerges after the necessary experience of the șūfī infidelity (. . . cunān-čih islām kih pīsh az kufr-i tarigat ast islām-i 'awāmm-i ahl-i islām ast wa is lāmī kih ba*d az kufr-i tarīgat ast islām-1 akhags:. al-khawāş). 39 Sirhind $\bar{I}$ strongly adheres to the classical șūfi distinction between the common people and the élite, 40 and frequently speaks of the common people with undisguised contempt. He uses for them expressions such as "common people who are like cattle" ('awāmm ka-’l-an'ām) or "bovine creatures" (bahā'im sifatān). Anything that might lead the ignorant masses astray must in his view be kept secret and even advanced disciples cannot be trusted with all the süfi insights. 41 
His contempt is a clear reflection of the idea, that the Isläm of the common people, uninitiated into the mysteries of tasawwuf, is far from being the objective towards which men should strive. That God in His boundless mercy made this kind of Islām sufficient for salvation in the crude, formal sense, does not mitigate Sirhindi's contempt for those who fail to transcend it. 3. ShI·a.

Aside from isolated references to the Khawārij, the ShI'a are the only Islamic sect to which Sirhindi pays attention in his works. An attempt to refute the shI'I doctrines was the subject of Sirhindi's first literary endeavour. As we have seen earlier, his Epistle on the Refutation of the ShI'Is was written in the pre-șufi period of his life. 42 It is marked by an exceptionally vigorous denunciation of the Shi'a and their role in Islamic religious history. In the beginning of the Epistle Sirhindi explains that his decision to write a refutation of the shI'I doctrine was prompted by the prophetic tradition demanding that the learned refute heretical ideas whenever they appear. He decided to fulfil this duty when he observed that "some of the followers of the ShI'a who frequented these regions boasted and were proud of these fundamental principles (of the shI' $\bar{I}$ faith) (mugaddimāt), and spread 
these fallacies in the councils of the princes and the kings". 43

Aside from this brief introduction, the Epistle consists of three parts. In the first part 44 Sirhindi describes the various shíI sects. Only in minor details are his descriptions different from those found in other heresiographies. In the second part 45 Sirhindi describes the shi'I takfir of the Companions of the Prophet and then launches his bitter attack upon the doctrines of the ShI'a.. Their adoration of 'AlI, says Sirhindi, is similar in its excesses to the Christian attitude to Jesus. 46 The shi' $\bar{I}$ books are unreliable and must be regarded to be as corrupted (muharrafa) as the Tawrāt and the Injīl.47 The Shīa do not refrain from adding spurious passages to the Qur' $\bar{a} n$ while accusing 'Uthmān of concealing Qur'ānic verses which had allegedly been revealed in praise of the Prophet's family. 48 The shI'I claim that 'AlI was nominated to succeed the Prophet is baseless, 49 and the consensus that elected Abū Bakr was full and included -Ali himself. 50 The most important passages of the Epistle are those in which Sirhindi declares that the Shi'a must be considered infidels and approvingly quotes legal opinions to this effect. We shall quote only a few of his most outspoken statements: "To say of a 
believer that he is an infidel is a cause of infidelity. A sound tradition runs as follows: Whoever accuses a man of infidelity and says (to him): 'Enemy of God'; and it is not true - if it is as he said (then all right); if not, it (i.e., the curse) will come back upon him. 91 Now we know certainly that $A b \bar{u}$ Bakr and - Umar are faithful, are not enemies of God, and have been promised Paradise. Their takfir therefore comes back upon those who pronounced it. According to this tradition, the ShI. $\mathrm{a}$ must be pronounced infidels." 52 Sirhindi also quotes with approval a legal opinion issued by a group of 'Transoxanian 'ulamä' who ruled: "Since the ShĪ'a permit cursing Abū Bakr, 'Umar, "Uthmān and one of the chaste wives (of the Prophet), which in itself constitutes infidelity, it is incumbent upon the Muslim ruler, nay upon all people, in compliance with the command of the Omniscient King, to kill them and to oppress them in order to elevate the true religion. It is permissible to destroy their buildings and to seize their property and belongings." 53

The third and last part of the Epistle ${ }^{54}$ contains traditions praising the members of the Prophet's family (ahl al-bayt). These traditions are intended to demonstrate the contrast between their virtues and the alleged moral depravity of the ShI'a and to prove that 
the ShI'a are unworthy of being heirs of those whose spiritual heritage they claim to preserve.

Such are the opinions regarding the Shi'a which Sirhindi expressed early in his life. We shall now look into the question whether he modified these opinions later, and if so, to what extent.

Sirhindi's attitude towards the ShI'a in the Maktūbāt is less hostile. He still maintains that their view of early Islamic history and their hatred for the three first khulafā. are misguided, but in most cases he refrains from declaring them infidels. Only in early letters to Mughul officials, written in order to persuade the recipients not to enter into any relationship with the ShI'a at their courts, are these passages in which the Shi'a are considered infidels. 55 In other letters Sirhindi applies the term kufr to shi' $\bar{I}$ doctrines only very rarely. 56 In comparison with the attitude of the Epistle, Sirhindi's approach to the ShI'a in the Viaktūbāt is rather mild. He continues to uphold the validity of the three first khulafā', but, on the other hand, stresses in several places that in the disputes which ravaged the Muslim community during 'AlI's term of office, 'AlI was in the right. The wrong stand taken by 'Ali's opponents was a result of a mistaken ijtihād made in good faith and cannot, therefore, be a reason 
for their exclusion from the Muslim community. Sirhindi points out that the Sunnis, contrary to the Khawārij, hold the members of the Prophet's family in high esteem. 57 It is significant that these statements, which seem to suggest a more conciliatory attitude towards the ShI'a, appear in works written during Sirhindi's şüfĩ period, while being conspicuously absent from the Epistle. The progressive mitigation of Sirhindi's hostility towards the ShI'a can be seen also from the fact that towards the end of his life Sirhindi concedes to 'AII and the tivelve a.imma a special spiritual task. The a'imma are said to be the leaders of those who approach God by the way of Sainthood and the transmitters of divine blessings to them. 58 Though the way of Sainthood is in Sirhindi's view inferior to the way of Prophecy, and though there is no indication of any change in his opposition to any public manifestation of shi' $\bar{i}$ influence at the imperial court or elsewhere, the passage referred to seems to indicate that even a fervent sunnì șüfi like Sirhindi is not able altogether to sever the manifold connections linking tasawwuf with sh $\bar{i} \cdot \bar{i}$ thought.

4. Falsafa.

In his criticism of the philosophers (alfalāsifa) SirhindI quotes al-GhazāII as his main source. 
The underlying idea of his reasoning is that human intellect is incapable of understanding properly the nature of God without prophetic assistance. The ancient Greek philosophers did not become aware of the existence of the Creator despite their intelligence ${ }^{59}$ and attributed the existence of things to dahr. ${ }^{60}$ It was only when the prophetic call became gradually stronger that the later philosophers rejected the view of their ancient predecessors and affirmed the existence of the Creator. They would not have been able to become aware of His existence without prophetic help. 61 Yet their concept of the Creator remains wrong. They deny His knowledge of the particulars (juz'iyyāt), consider him denuded of attributes (mu'attal ) and without a function in the world ( $\underline{\bar{i}-k \bar{r}})$. The only thing that originated with Him in their view is the "active intellect" (aql-i $\underline{\left.f_{a} \cdot \bar{a} 1\right)}$. This entity, says Sirhind $\mathbf{I}$ does not exist save in the philosophers' imagination; yet they persist in tracing to it the origin of the events that take place in the world instead of recognizing God as the only force behind them. Some of them deny Prophecy, 62 and even those who accept it reject the content of essential parts of the Qur'ān, such as the bodily resurrection and the events connected with it. Their denial of God's knowledge of the particulars leads them 
to the rejection of divine laws. Consequently, they are stubborn and ignorant people and must be regarded as infidels. 63

The harsh judgment passed by Sirhindi on the philosophers' metaphysics leads him to an equally indignant rejection of their natural sciences. Their geometry, astronomy, logic and mathematics are useless as far as the hereafter is concerned and fall therefore within the category of the "inconsequential things" (mā là ya'nì). They must not be dealt with except in cases in which they are indispensable for the strengthening of a shar'I science. These cases are extremely rare; and if a person is concerned with the sciences of the philosophers, it is a sign that God has withdrawn His

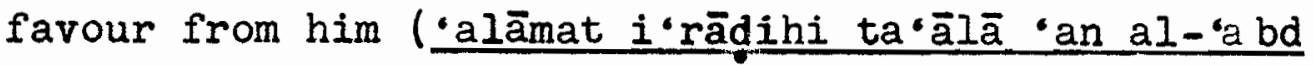
ishtighāluhu bi-mā lā ya'nīhi). Quoting al-Ghazālī's al-Munqidh min al-Dalàl as his authority, Sirhindi asserts that the best sciences of the philosophers, namely ethics (tahdhib al-akhlāg) and medicine (țibb) have been stolen from the books of the Prophets. ${ }^{4}$ So great is Sirhindi's abhorrence of any non-religious occupation, that he admonishes against even the study of Sa'di's popular Būstān and Gulistān, 65 though elsewhere he himself quotes from these books verses that illustrate his point. 66 
In the material summarized above Sirhindi claims several times that he bases his rejection of the philosophers on the works of al-Ghazäli. It must be pointed out, however, that while there are basic similarities between the two thinkers, such as the rejection of the philosophers' metaphysics and the belief in the fundamental inadequacy of the human intellect to arrive at certain religious truths, their views regarding the philosophers are far from identical. This is especially true of their respective approaches to the natural sciences. Unlike al-Ghazālí, Sirhindī does not discuss separately the merits or otherwise of each science; he lumps together all the philosophers and all their sciences and rejects them in toto. While alGhazāli approaches the question with a well-balanced argument and uses relatively moderate language, Sirhindi's approach is emotionally charged and his language largely vituperative. 67 These differences notwithstanding, there can be no doubt about the basic dependence of Sirhindi on al-Ghazāli in this field. This dependence is brought into relief also by the fact that Sirhind $\bar{I}$ does not take cognizance of the philosophical developments after al-Ghazāli, and the only philosophers mentioned in his works are al-Fārābī and Ibn Sīnā. 


\section{Theology (kalām).}

When compared with his views of the philosophers, Sirhindi's attitude to the theologians (mutakallimün) seems to be sympathetic, though they, like the "superficial" "ulamā", also cannot reach the highest stage of divine awareness. Both the şüfis and the theologians strive to attain the knowledge of God (ma"rifat-i khudā), but each group understands this term in its own peculiar way. The șūfīs, who maintain that the way to attain the objective is the suppression of the evil-bidding soul (riyāźat-i nafs) and the purification of the inner self (tasfiya-yi bāțin), understand knowledge as "expanded ecstatic perception" (daryāft-i basīt_-i wijdānī) ${ }^{68}$ The theologians, whose way is that of demonstrative reasoning (nazar o istidlāl), understand it as "formal affirmation and belief" (șürat-i tașdiqi o Imānī). The knowledge of the sūfis, expressed by the verbs shinākhtan and yāftan, is a result of their awareness of the divine presence (‘ilm-i huzüuri); in their case, says SirhindI, "the known is not outside the essence of the knower" (yāft dar bīrūn-i dhāt-i yābandah namī-bāshad). On the other hand, the knowledge of the theologians, expressed by the verb dānistan, is acquired (ilm-i hussūi I) by an intellectual process and comes from outside. 69 The knowledge of the theologians 
is therefore of a different kind and of a lesser value than that of the șüfis.

Sirhindi maintains that the rational arguments of the theologians, though intended to strengthen the faith, are liable to have the opposite effect. This weakening is caused by the fact that human reason is not capable of providing rational proof for certain articles of faith, such as the vision of God in the hereafter or the doctrine of God creating the acts of men by creating in men the power to perform each act (al-istița'a ma'a al-fi(1). Both these tenets are correct, but the rational arguments adduced by the theologians to support them are deficient. The deficiency of the supporting argumentation creates doubts regarding the tenets themselves. Sirhind of theology, which in his view kept aloof from "philosophical subtleties" (tadqİāt-i falsafiyya). On the other hand, he opposes al-Ash'arī, who introduced the method of demonstrative reasoning (nazar o istidlāl) among the sunnī 'ulamā'. Al-Ash'ari's intentions were commendable: he wanted to strengthen the faith by the use of reason. This task is, however, difficult. 70 Sirhindi therefore maintains that articles of faith must not be subjected to the test of reason, which is ill-equipped to demonstrate their validity. 
To investigate Sirhindi's claim that the Miāturīiyya remained aloof from what he calls "philosophical subtleties" is beyond the scope of this work. Goldziher thinks that the Māturidiyya occupy a middle position between the Mu'tazila and the Ash'ariyya; ${ }^{71}$ if this is the case, Sirhindi's statement is rather difficult to understand. It is likely that Sirhindi's preference of the Māturídiyya is caused mainly by factors other than al-Māturīī's peculiar views on theology, which, in any case, do not play an important role in Sirhindi's thought. His preference is probably related to the connection between the Māturīi school of theology and the Hanafi school of law, 72 which Sirhindi supported for reasons that have already been explained. As for specific theological questions, Sirhind deals with them on two different levels. At one level, he reiterates the position taken by the classical theologians on subjects such as free will and acquisition ( $\underline{\text { kasb) }}$, the hereafter, the pillars of Islām (arkān), the vision of God (ru*ya) and the like. Sirhindi deals with the theological issues in this manner mostly in letters to government officials or to șüfis who are beginning their training. Usually these letters do not deal with one specific subject, but are rather long and comprehensive statements outlining the 
proper beliefs that ought to be held and the proper practices that ought to be followed. They seem to be a sort of manual of belief and practice given to persons who join the order or whom Sirhindi wishes to bring within his sphere of influence. 74 On the other level, some of these theological subjects are discussed also in connection with Sirhindi's appraisal of Ibn al-Arabi's world-view. Especially such subjects as the relationship between the divine essence and its attributes and the vision of God are of importance for his stand toward Ibn al-'Arabi. It is appropriate therefore to consider these traditional theological subjects in our analysis of Sirhindi's approach to Ibn al-'Arabi, which will follow in due course. 


\section{CHAPTER VI}

\section{SIRHINDI'S VIEW OF THE ISLAMIC TRADITION: II}

\section{The early sūfis.}

Sirhindi's view of the early șüfis is very instructive with regard to his understanding of the şūfi experience. Acting upon the principle that "the words of the intoxicated have to be interpreted (allegorically) and turned away from (their) outward meaning" (fa-inna kalām al-sakārā yuhmal wa yusraf 'an al-zāhir), ${ }^{1}$ Sirhindi can regard even the most ecstatic șūfi statements as a legitimate expression of a certain stage in the development in the Muslim consciousness of the Divine. To achieve this end Sirhind I occasionally adduces explanations which are all but unacceptable on linguistic grounds, but which are well integrated within the comprehensive framework of his thought.

Sirhindi's attitude towards al-Hallāj is a case in point. We have already seen the interpretation given by him to the verse in which al-Hallāj declared that he had "denied the religion of God". 2 Elsewhere Sirhindi deals with the famous ana al-haga, and it is in connection with this utterance that he makes his major effort to "justify" and "excuse" al-Hallāj. 
Sirhindi's interpretation of ana al-hagg is related to the distinction he makes between the theories of the Unity of Being (wahdat al-wu,jūd, tawhīd-i wujūji and the Unity of Appearance (wahdat al-shuhūd, tawhīd-i shuhūdi)). Unity of Appearance means "to see One, namely nothing but One is seen by the șūfi" (tawhīd-i shuhūdI yaki dīdan ast ya'nI shuhūd-i sālik juz bar yakĩ na-bāshad). Unity of Being, on the other hand, means "to consider Existence as One, to regard everything else as non-existent and to consider the manifestations of that (One) as one, despite their nonexistence" (tawhīd-1 wu,jūd I yak wujūd danistan wa ghayr-i $\bar{u}-r a \bar{a}$ ma $d u \bar{u}$ angāshtan wa bā wu.jūd-i 'adamiyyat ${ }^{3}$ majālì o mazāhir-i ān yaki pindāshtan). Sirhindī exemplifies this distinction by describing two views which a person can take of a natural phenomenon. The wujū $\bar{I}$ would deny the existence of the stars while looking at the sun because he is overwhelmed by the spectacle and cannot see anything except the sun itself. His view is patently wrong. The shuhūdi, on the other hand, knows that the stars do exist, though he also sees only the sun. His consciousness is in the stage of ayn al-yagin, while that of the wujūdi remains at the lower stage of ilmal-yagin. The highest stage of consciousness, that of hagq al-yaqin, can be reached when the 
sight of the onlooker is sharpened to an extent that enables him to see the stars and the sun simultaneously. ${ }^{4}$ The controversial utterances of the șüfis, says Sirhindi, have to be understood in terms of Unity of Appearance, which is not inconsistent with proper Islamic belief. These utterances, such as ana al-hagg and subhānī, were made when ecstasy prevented the șüfīs from seeing anything except God. They, therefore, do not affirm the existence of anything except Him. "Ana al-hagg means 'God exists, not I' - he (i.e. al-Hallāj) does not see himself and therefore does not affirm (his own existence); it does not mean that he sees himself and considers himself God" (wa ma"ni-yi ana al-hagg ān ast kih hagq ast na ${ }^{5}$ man čūn khwudrā namī-binad ithbāt

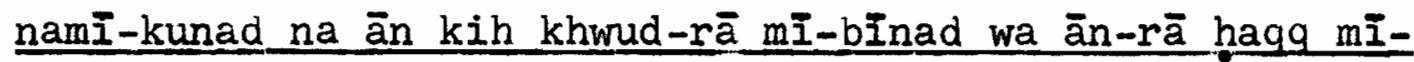
gūyad). Lack of affirmation, says Sirhindi, is not tantamount to denial. 6 In another passage, he approvingly quotes his mentor al-Bāqĩ bi-’llāh who said that ana alhagg does not mean "I am God" (man haqgam), but "I do not exist, what exists is God" (man nistam wa mawjūd haqg ast subbānahu). 7

The obvious linguistic difficulties involved in this exegesis bring Sirhindi's determined effort to retain al-Halla $j$ within the fold of Islām into sharp relief. A similar effort is discernible in his inter- 
pretation of subhāni. This utterance aims in Sirhindi's view at the tanzih of God, not of Abü Yazid. 8 Both these explanations have to be read in conjunction with Sirhindi's theory of the perfect man (al-insān al-kāmil), who has attained "subsistence in the Essence" (bagā-yi dhātI) and therefore never uses the word "I" (ana) for himself. 9 They are also comparable to the explanation of Suhrawardi, who thought that al-Hallāj had said ana al-hagg "by way of narrative", speaking not for himself,

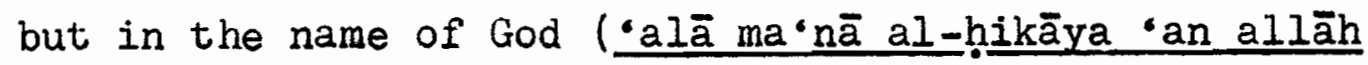
ta $(\bar{a} l \bar{a}) .10$ This explanation is approvingly quoted by Sirhindi. 11 In adopting it, Sirhindi continues a long standing tradition of the șüfis, most of whom refused to identify themselves with al-Hallāj's detractors. 12 Sirhindi's views of the ecstatic utterances of the early șüfis should be understood also in the light of his description of the various degrees of religious consciousness, with which we have dealt earlier. ${ }^{13}$ The utterances are to be seen as expressions of the stage of "șūfi infidelity" (kufr-i țarigat), legitimate in themselves, but not insurpassable. It is, therefore, not surprising that Sirhind $I$ envisages a stage beyond that arrived at by these intoxicated süfiss. The way in which their spiritual achievements can be improved upon is explained in Sirhindi's discussion of Rābi'a al-'Adawiyya 
in Mabda o Ma'ād. This passage is characteristic of the interplay of sunni and șūfi ideas in Sirhindi's thought and exemplifies his theoretical preference for sobriety over intoxication. It deserves to be translated in full: "Once upon a time a group of șüfis were sitting together. I spoke of my love for the companions (ghulāmān !) of the Prophet in the following words: I have been overwhelmed by the love of the Prophet to such an extent that I love God (only) because He is the Master of Muhammad.' Those present were amazed at this talk, but they could not express their opposition. This statement (of mine) is contrary to that of Rābi ‘a who said: II told the Prophet in a dream: "I have been overwhelmed by the love of God to such an extent that there remains no room for loving you." Both statements indicate (that they have been made in the stage of) intoxication, but my statement has genuineness (a she spoke in the very midst of intoxication; I spoke at the beginning of sobriety. She spoke (while being) at the stage of Attributes; I spoke after returning from the stage of the Essence. At the stage of the Essence there is no room for this kind of love. No relationship can reach this stage; everything there is either bewilderment (hayra) or ignorance (jahl). Moreover, (the șūfi) by his dhawg denies love at this stage and 
does not consider himself deserving to love God in any way. Love and ${ }^{1 / 4}$ gnosis exist at the stage of Attributes only. The love of the Essence (mahabbat-i dhātĨ) about which they (i.e. the șūfís) spoke - its meaning is not the Essence of Oneness (dhāt-i ahadiyya), but the Essence with several of its Attributes. Thus the love of Rābi'a is at the stage of Attributes. God inspires the truth." 15

Thus, Sirhindi refrains from censuring the early sūifs for their ecstatic utterances, though he is convinced of their deficiency. His guiding principle is to refrain from creating dissension in the community. This attitude is significantly different from Sirhindi's views in the days before he joined the Naqshbandi order and when he wrote such violent denunciations of dissenters as the Epistle on the Refutation of the Shi'a. His rather catholic attitude towards the șüfiss reaches its fullest expression when he has to defend himself against critics who resented his own ecstatic statements. At the end of letter 121 of the third volume, which is a reply to 'Abd al-Haqq Dihlawī's criticism of Sirhindi's claim to spiritual eminence, Sirhindi says that utterances divulging secrets have always been made by the șūfiss. He continues: "Thus, what is all this commotion? If a statement has been made whose outward meaning does not 
conform to the shar'I sciences, it should be turned away from its outward meaning and made to conform (with them) out of consideration (with him who uttered it). One must not level accusations against a Muslim. To expose a whore or a sinner is always forbidden and blameworthy according to the shari'a; how can then a Muslim be put to shame on the basis of mere ambiguity? What kind of religiosity is it to spread (unfounded rumours about him) from town to town? The way of Islām and kindness is first to find out who made the utterance whose outward meaning contradicts the shar'I sciences. If he is an heretic, it should be refuted and no effort should be made to correct him. (But) if he who made the utterance is a Muslim and believes in God and the Prophet, an effort must be made to emend his words, to give them correct explanation or to ask for an explanation from him. If he is unable to furnish a correct explanation, one must give him good advice. It is desirable to enjoin good and forbid evil in a gentle way, because this is likely to bring about repentance. If the objective of repentance is not reached and it is required to expose the matter, this is another thing." 16 2. Ibn al-'Arabi.

SirhindI's attitude to Ibn al-'ArabI is one of the most intricate and difficult questions which we 
must discuss. Modern writers have stressed SirhindI's role in controverting Ibn al-'Arabi's theory of wahdat al-wujūd, which was in their opinion unIslamic and prejudicial to the survival of the Muslims of India as a distinct religious community. ${ }^{17}$ It is not our intention to enter here into a detailed description of wahdat alwujūd and wahdat al-shuhūd. We have referred to these two theories briefly in the preceding section, and a full description of them can be found in B. A. Faruqi's The Mujaddid's Conception of Tawhid. We should like rather to concentrate on Sirhindi's view of Ibn al-“Arabī as a thinker and on the reasons given for the differences with Ibn al-'Arabĩ.

We have seen in the preceding section that Sirhindi does not dissociate himself from the early șufís whose ecstatic utterances made them suspect in the eyes of the 'ulamā' and occasionally even brought about their execution. He maintains that these utterances, if properly understood and interpreted, constitute a legitimate expression of Muslim religious experience. It seems to us that his attitude towards Ibn al-"ArabI is not essentially different. Sirhindi is critical of certain aspects of Ibn al-'Arabi's teaching, but this criticism does not prevent him from appreciating Ibn al'Arabi's contribution to tasawwuf as a whole. 
Let us first discuss some of the differences between the two thinkers. Sirhindī criticizes Ibn al-Arabi for saying that the Vision of God in the hereafter will be "in symbolic form" (bi-sürat-i mithāliyya). Since God (hagq) does not have any form, Ibn al-'Arabi's view is, according to Sirhindi, tantamount to a virtual rejection of the Vision and resembles the views of the Philosophers and the Mu'tazila. 18 Sirhindi opposes Ibn al-'Arabi's view of the Attributes by asserting that the "essential" ones (șifāt-i haqĩqiyya) exist independently of and in addition to the Essence. 19 He also disagrees with Ibn al-'Arabi on the nature of the divine presence in the world. 20 Perhaps the most important area in which Sirhindi departs from the theory of Ibn al-AArabi as he understood $i^{21}$ is the nature of the existence of the phenomenal world. It is Sirhindi's understanding that Ibn al-AArabI denied any independent existence of the world and thought that it existed only in the imagination of the common people. Sirhind $\bar{I}$ agrees that the world, indeed, is mere imagination (wahm), but adds that it has been given a measure of stability and permanence (thubüt o thabāt) by divine volition. It is not imaginary in the sense that it appears only in the people's imagination, but in the sense that God created it to be such. It therefore has a kind of independent 
existence, though not comparable with the Existence of God. This independent existence is important, because it allows for the Wuslim idea of reward and punishment. In this exposition Sirhindi sees himself as adopting a position intermediate between the 'ulama'. who maintain that the world "really" exists and Ibn al-"Arabi and his followers who deny that the world has any existence at all. 22

Nevertheless, Sirhindi recommends the study of Ibn alsArabi's works and considers them indispensable for the proper appreciation of his own spiritual insights. 23 Frequently he quotes Ibn al-'ArabI's works approvingly. 24 Those of Ibn al-“Arabi's opinions which are unacceptable should be viewed benevolently; they are similar to bona fide errors of a mujtahid, and Ibn al-Arabi should not be blamed for holding them. 25 Occasionally Sirhind $I$ even seems to be uneasy when he expresses opinions which are at variance with those maintained by Ibn al-'Arabi. In one of the letters included in the third volume of the Maktübāt, Sirhind $\bar{i}$ criticizes the views of Ibn al-'Arabī regarding the Vision of God (ru'ya). As if he were astonished at his own courage to criticize the great master, he continues: "Oh God! What can I do in this battle-field? It is the Shaykh (i.e., Ibn al-‘Arabi) with whom I sometimes fight and sometimes 
agree. It is he who laid down the foundations of the theory of gnosis (sukhan-i ma'rifat o irfān) and elaborated on it. It is he who spoke in details about Unity (tawhid) and Union (of the Creator and the creature) (ittihād) and who explained the emergence of Multiplicity (ta.addud o takaththur). It is he who attributed Existence solely to God (haqg) and asserted that the world was imaginary (mawhūm o mutakhayyal). It is he who established the stages (tanazzulät) of Existence and distinguished between the qualities of each stage. It is he who considered the world to be essentially identical with God (' àlam-rā 'ayni-i hagd dānista ast) and who said 'All is He' (hama üst); this notwithstanding, he found the stage of His transcendence (tanzih) beyond the world and considered Him too remote and too pure (munazzah o mubarra') to be seen or known. The şüfis who preceded him, - if they spoke about these matters at all, - only hinted at them and did not elaborate. Most of those who came after him chose to follow in his footsteps and used his terms. We latecomers ( $m \bar{a}$ pas māndagān $)$ have also benefited from the blessings of that great man and learned a great deal from his mystical insights. May God give him for this the best reward." 26

It should be kept in mind that the above-quoted 
passage was written late in Sirhindi's life. It is clear that even in this period Sirhindi maintains a very respectful attitude towards Ibn al-“Arabi. He does not condemn him for his opinions, but rather attempts to interpret his controversial statements in a way that would render them compatible with what he considers to be the proper Islamic belief. It is not surprising that the crux of the matter is the interpretation to be given to the famous "All is He" (hama üst). Although in an early letter Sirhindi seems to understand this expression as indicating phenomenological unity between God and the world, 27 he later explains that it does not imply that God dwells in the material world (hulūl) or is united with it (ittihād). It means only that beings are manifestations of the one Divine Essence. The Essence does not dwell in them, is not united with them and not influenced, coloured or augmented by them. 28 Another explanation given by Sirhindi to hama ust is analogous to his understanding of ana alhagg. The latter sentence is taken to mean "I do not exist, what exists is God"; in parallel fashion, hama üst would mean "All does not exist, what exists is He" (hama nistand mawjūd $\bar{u}$ st). This interpretation is likewise devoid of any implications of phenomenological unity between God and the world.29 In other words, "All is He" 
should be understood "All is from Him" (hama az ūst); according to Sirhind $i$ this is the meaning in which the wujūjī șüfis intended it to be understood. 30 The two phrases are therefore not contradictory, but rather two expressions of the same truth.

Despite the extensive treatment of this matter and the detailed exposition of questions related to it by Ibn al-'ArabI, some of the şufis failed to understand him properly and condemned him on account of his views. The truth of the matter is, says Sirhindi, that "in most assertions about reality (tahgīaāt) the Shaykh is in the right and his detractors far from the truth. From the investigation of this matter one ought to learn about the greatness and the profound wisdom of the Shaykh, not to refute and condemn him. The more (the discussion of) this question continues, . . the more remote become any suspicions of a doctrine of indwelling (hulūl) and unity (between God and the world) (ittihād) . . ."11

What are the conclusions which Sirhindi draws from this analysis of the relationship between the respective world-views of the șüfis and the "ulamā'?

Both the șüfis and the 'ulamā' are willing to accept "All is from Him", though they do not understand it in the same way. The culamā. maintain only that the 
world has its origin in God; the șüfis accept this view, but maintain also that the world is a shadow of the divine perfections. Though this latter point is not understood by the "ulama', for which reason they are unable to reach the spiritual heights attained by the șüis, 32 the gap between the two groups is bridged as far as essentials are concerned. Sirhind $\bar{I}$ is, therefore, able to demonstrate that the differences between the wujūdi şufis and the "ulamā' are unessential and result only from varying modes of verbal expression. 33 By adopting this view Sirhindi can take up the cause of Ibn al- Arabi and his followers without unduly antagonizing their opponents among the ranks of the "ulamä. In other passages, however, he clearly dissociates himself from the attitude of the latter. To ascribe real existence to the world, as the ulamä. do, is in his opinion a kind of polytheism: it amounts to an assertion that God has partners in the most exclusive of his attributes, namely Existence. 34

It is not easy to arrive at a meaningful evaluation of the differences between Sirhind $\bar{I}$ and Ibn al-'Arabi. In the Maktūbāt we are faced with many seeming contradictions, which do not easily lend themselves to an acceptable interpretation. We have seen that SirhindI understands the famous hama üst in two different ways. 35 
In an earlier chapter we have referred to his description of the prophetic descent (nuzūl) in which he implies that at this stage any distinction between hagq and khalg is meaningless. ${ }^{36}$ Such a doctrine seems to be in glaring contradiction to many passages in which heavy emphasis is laid upon the absolute separateness of hagg and khalg. It is also significant to note that while in a letter included in the first volume of the Maktūbāt Sirhindi accepts the view of those who maintain that the world exists independently due to divine creation ( $\bar{a}$ lam bi-Ijjād-i hagq subhānahu dar khārij maw,jūd ast), 37 he later stresses that its existence is imaginary (mawhüm), though with a degree of permanence. 38

The material at our disposal is too equivocal to enable us to state categorically that Sirhindi's view of Ibn al-'Arabi developed in any particular direction with the passage of time. Likewise, the lack of sufficient biographical material about the addressees of the letters included in the Maktūbāt prevents us from substantiating our assumption, that at least some of the contradictory statements made in the various letters are due to differences in the spiritual capacities of the recipients, as Sirhindi saw them. On the other hand, there is no evidence to support the prevalent view according to which Sirhind $\bar{I}$ had been in the beginning a 
follower of Ibn al-'Arabi, and only later came to realize the deficiencies of Ibn al-'Arabi's world-view. We assert this despite the fact that this view is based on SirhindI's own description of his spiritual development in a letter included in the first volume of the Maktūbāt. 39 Sirhindi''s self-image, as expressed in the early period of his life and even later, does not tally with the content of the Maktūbāt as a whole. Most of the letters in which SirhindI gives sympathetic interpretation to Ibn al-'Arabi's views and criticizes those who failed to understand the true meaning of the great master's works, were written late in Sirhindi's life. 40 Thus, if there was a development in Sirhindi's views on this matter, it is likely that he moved towards a sympathetic appreciation of Ibn al-'Arabi rather than away from it.

It also seems to us that SirhindI's criticism of the wahdat al-wujūd theory is a result not only of his disagreement with some of its constituent ideas. It springs also from his fear that the theory might lead common, uninitiated people to heresy and neglect of the shari'a. Sirhindi fears such result even though he stresses that the accomplished adherents of wahdat al-wujūd "have reached perfection" (in ţāifa wāșil o kāmil and) and are not to be blamed. 41 The criticism 
of Ibn al-"Arabi is thus due at least partly to SirhindI's conviction that certain şüfi "secrets" have to be withheld from the public because of their potentially harmful effect upon the uninitiated.

It is, therefore, our conclusion that Sirhindi's rejection of Ibn al-'Arabi is far from being as complete and unequivocal as is generally believed. His criticism of Ibn al-'ArabI is widely different from that of the "ulama', not only in the way in which it is arrived at, but also in its essential features. In view of all this, and with due allowance for the complexities involved, we suggest that Sirhindi should not be regarded as a thinker who rejected hama üst and replaced it with hama az üst, but rather as one who interpreted the former expression by the latter, for the sake of clarity and because of the danger of misinterpretation by the uninitiated.

3. the Nagshbandi order.

As we have seen earlier, Sirhindi was initiated into the Naqshbandī order by Khwāja al-BāqI bi-’llāh in 1008/1599-1600. This initiation was an event of major importance in his life. His religious outlook was transformed; and he became convinced that the Naqshbandi discipline was the shortest, fastest and only way to the pinnacle of spiritual achievement. The Naqshbandis, says 
Sirhindi, begin their spiritual journey where the other şüis end theirs. This "inclusion of the end in the beginning" (indirāj al-nihāya fī al-bidāya) is the Leitmotiv in Sirhindi's descriptions of Naqshbandi superiority. 42 Sirhind I explains, however, that this does not imply equality between a beginner in the Naqshbandi order and an advanced disciple in another one; it merely means that the Naqshbandi shaykh shares his advanced stage with his beginning disciple. This early sharing has in turn a salutory effect on the final achievements of the Naqshbandis. 43 The way of the Naqshbandis is absolutely identical with that of the Companions, and they have the same rank. 44 One step in their way is better than seven in any other one; this is the way leading to the perfections of Prophecy, while the other ways have to be content with the attainment of Sainthood. 45 Though certain innovations have crept even into the Naqshbandiyya, 46 this order is still superior to the others which are guilty of many reprehensible customs, such as listening to music (samä). This custom is unable to induce any real spiritual achievement and is characteristic of people suffering from spiritual instability (tagallub-i ahwāl). Practices asøociated with it, such as dancing (rags), singing 
(naghma) and ecstatic sessions (wajd, tawājud) are also objectionable. Prayer can perform their function much better. 47 
CHAPTER VII

\section{THE INDIAN ENVIRONIHENT}

The subjects with which we have been dealing so far have no particular connection with India. It is time now to consider SirhindI in the context of his Indian environment.

Sirhindi has been credited with a major role in the development of Islām in India. It is therefore rather surprising that India, its history, its people and the conditions prevailing there in Sirhindi' time do not occupy a much more central position in his thought. Sirhind $\bar{I}$ does not regard the contribution of the Indian Wuslims of Islamic culture very highly, is conscious of their great indebtedness to the culama'. of Transoxania and speaks of India as the "lower country" ( diyār-i suflā) as against Transoxania which he designates as "upper". ${ }^{l}$ An overwhelming majority of his work deals with problems that are of no more concern to the Muslims of India than to their co-religionists in other countries. Denunciations of Hinduism and attacks on the Hindūs, which have become one of the main themes in modern analyses of Sirhindi's historical significance, ${ }^{2}$ actually play only a peripheral role in his thought. 
Even subjects that could have specific relevance to the conditions prevailing in India in the 16th and 17th centuries are frequently presented without any reference to these conditions. Sirhindi's Epistle on the Refutation of the ShI'a is a case in point. Sirhindi might have been prompted to compile it by the growing influence of the ShI' in the iughul court. Yet, except for a brief reference to shī $\bar{I}$ propaganda in "these regions" at the beginning of the Epistle, 3 he does not pay any attention to the circumstances which enabled shi' $\bar{I}$ Islām to gain a foot-hold in India. He discusses at considerable length the events that led to the elevation of $\mathrm{Abu}$ Bakr to the khilāfa in 632, but does not mention at all the Safawi neighbours of the Mughuls, some of whom were instrumental in the introduction of $s h \bar{I} \cdot \bar{I}$ Islām into the subcontinent. 4 SirhindI is interested in the problem within its classical frame of reference and entirely ignores the form in which it manifested itself in 16 th and 17 th century India. This is another indication of the fact, that Sirhindi is primarily a șūfĩ and a theologian, and not a person preoccupied with problems of a particular historical period. All this notwithstanding, our description of Sirhindi's works would not be complete without considering those few elements in his thought that clearly are the product 
of his Indian environment.

We have seen earlier that Sirhind $\mathrm{I}$ vigorously objects to the introduction of innovations (bida', sg. bid'a) into Islamic culture. However, his exhortations to this effect are general, and he rarely attacks specific deviations from what he considers to be the proper form of Islamic practice. The few examples adduced to illustrate his views on the matter are random and do not constitute a systematic attack on the (un)Islamic practices current in his time and place. ${ }^{5}$ Only in a single letter does he deal with innovations peculiar to the Muslims of India. This letter (volume 3, letter 4l) is addressed to an anonymous șūfí lady (yakī az sālihāt) and deals mainly with the "pledge of women" (bay'at al-nisā') at the time of Muhammad. ${ }^{6}$ Sirhindi expresses his conviction that women are more prone to blameworthy actions than men and then proceeds to describe the innovations common among Indian Muslims, chiefly women, in his time. Because of their utter stupidity women pray to stones and idols and ask for their help. This practice is common, especially when small-pox strikes, and there is hardly a woman who is not involved in this polytheistic practice. Women participate in the holidays of Hindūs and Jews. They celebrate the festival of Diwāli and send to their sisters and daughters presents 
similar to those exchanged by the infidels. They sacrifice animals at the tombs of șūfĩ saints, even though this custom has been branded as polytheistic in the books of Islamic law. They observe fasts in honour of saints, though God alone is entitled to this homage. Having finished the fast, they commit various sins. All this, as well as other sinful practices, is in violation of the conditions upon which the Prophet accepted the "pledge of the women".7

Despite the fact that Sirhindi's Islamic consciousness is barely qualified in any way by his being Indian, Sirhindi is confronted with the questions of India's status from the theological point of view and of the attitude which iuslims should have towards its Hind $\bar{u}$ inhabitants. To give an answer to these questions is for him a rather difficult task. A Muslim can learn from his classical sources what attitude he should adopt towards the Jews and the Christians and what is their position in the spiritual history of mankind. He cannot do the same with regard to the Hindūs. The first question which Sirhindi has to answer in order to clarify their status is whether Prophets have been sent to their country or not. Sirhindi's reply is that Prophets were sent to India, but all were rejected, and none had more than three followers. They were not successful in 
founding a community, and we, therefore, do not have any reliable information concerning them; who would have transmitted the information and who would have been there to receive it? Moreover, the Indian language did not have the necessary words to transmit information about the Prophets. Hence, there is no verbal tradition about the prophetic missions to India, but there are some gruesome reminders of them. Probably having in mind the Qur'annic traditions about the extinct communities of $\overline{A d}$ and Thamūd, Sirhind says that the ruins scattered all over India are those of towns and villages which rejected the Prophets and which were consequently destroyed by the divine wrath. 8

Yet these Prophets did exercise some influence upon the spiritual life of India. Whatever the "leaders of Indian infidelity" (ru'asā'-ikufr-i hind) know about the necessary existence of God, they learned from these unsuccessful apostles, very much like the Philosophers.9 Going back to the classical notion that reason alone is not sufficient to bring about awareness of God, Sirhindi says that the lame and blind intellects of the Brahmins could never have reached the good fortune of this awareness without prophetic guidance. Yet despite their indebtedness, the Brahmins misuse the knowledge communicated to them, falsify the message by claiming 
that the Divine is dwelling (hāll o sārî) in them and induce people to bestow divine worship upon their own persons. 10

The above is one way in which Sirhindi attempts to disparage the spiritual achievements of the Hindus. He tries to achieve the same objective also by evolving a theory concerning the respective merits of religious duties (farā'id), works of supererogation (nawāfill and acts of mortification (riyādāt, mujāhadāt). The subjugation of the carnal soul, which ought to be man's highest aim in this world, can be effected solely through the performance of works prescribed by the shari'a. Works of supererogation are of any value only when supplementing the religious duties. The fulfilment of one commandment brings man nearer to his purpose than a thousand years of mortification independent of the shari'a. A penny given as zakāt is better than thousands of dinārs spent on charity without reference to the Qur.ānic commandment. Acts of self-denial performed independently of divine precepts may even be a source of strength for the carnal soul. Thus the Hindū Yōgis and the Greek Philosophers, who lose no opportunity of selfdenial, are actually engaged in an exercise in futility. 11 The preference of the prescribed religious duties over the supererogatory works is of such fundamental 
importance to Sirhindi that he deems it necessary to incorporate it even in his cosmology: the supererogatory

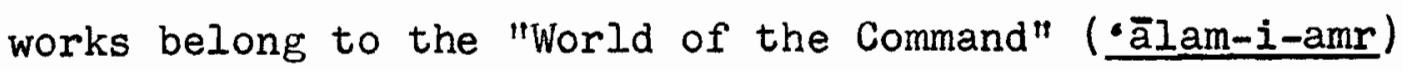
and enable the worshipper to approach merely the shadow of the Ultimate Reality (qurb-i zilli)), while the religious duties are part of the "World of Creation" ('ālam-i-khalg) and lead the believer to the proximity of the Essence (qurb-i-ass.1ㄱ). 12

Sirhindi's critique of Hinduism is given in the most succinct form in a letter addressed to one Hirday Rām. This letter is the only one in the Maktūbāt which was sent to a Hindu and also the only one in which Sirhindi expresses his views on a few details of the Hindu tradition. Significantly, the letter begins and ends without any benedictory formulae, so copiously used by Sirhind $\bar{I}$ in the rest of his correspondence. It constitutes a reply to two letters which Sirhindi received from Hirday Rām. From Sirhindi's description of these two letters ${ }^{13}$ and from his reaction to their content, it seems likely that Hirday Rām expressed in them his desire to join the Naqshbandi order without first accepting Islām; he probably based his request on the belief that all religions are essentially identical and that formal conversion would thus be meaningless and superfluous. It is not surprising that 
such a request and the ideas accompanying it were abhorrent to Sirhindi. His reply is devoted in its entirety to a devastating and scornful attack on Hinduism, on thehuman characteristics of the Hindū deities and on the idea that Rām and Rahmān are one and the same. ${ }^{14}$ It is noteworthy that Sirhindi does not formally urge his correspondent to accept Islām, though he says that "one should use farsighted intelligence and refrain from following them" (i.e. the Hindu deities). ${ }^{15}$ This omission is significant, for it faithfully reflects Sirhindi's general disinterestedness in questions of conversion. His concern is limited to the Muslim community only. Sirhindi's disciples and followers claim that Sirhind $I$ was engaged in widespread missionary activity, but there is no sound historical evidence to substantiate this claim. 16

Sirhindi follows up his utter rejection of the beliefs and practices of Hinduism by an equally outspoken attitude regarding the position of the Hindus in the Mughul empire. The honour of Islam demands the humiliation of the infidels and of their false religion. To achieve this objective, jizya should be mercilessly levied upon them, and they should be treated like dogs. Cows should be slaughtered to demonstrate the supremacy of Islām. The performance of this rite is, in India, 
the most important symbol of Islamic domination. One should refrain from dealing with the infidels unless absolutely necessary, and even then treat them with contempt. Islām and infidelity are two irreconcilable opposites. One thrives upon the degradation of the other. 17 Sirhindi's deep-seated hatred of the nonMuslims can be best illustrated by his rejoicing at the execution in 1606 of Arjun, the fifth guru of the Sikhs. In a letter to Shaykh Farīd Bukhārì Sirhindī says: "These days the accursed infidel of Goindwāl was very fortunately killed. It is a cause of great defeat for the reprobate Hindūs. With whatever intention and purpose they are killed - the humiliation of infidels is for the Nuslims life itself . . " (dar In wagt kushtan-i kāfir-i la 'In-i goindwāl bisyār khūb wāqi' shud wa bā'ith-i shikast-i 'azim bar hunūd-i mardūd gasht bi-har niyyat kih kushtah bāshand wa bi-har gharaz halāk kardah khwārī-yi kuffär khwud naqd-i waqt-i ahl-i islām ast). 18 Elsewhere he says: "Whenever a Jew is killed, it is for the benefit of Isläm" (juhūd har kih shawad kushtah sūd-i islām ast). 19

Shaykh Muhammad Ikräm has suggested 20 that Sirhindi softened his attitude towards the Hindus at the end of his life. He quotes letter 22 of the third volume as evidence for this thesis. In the letter 
Sirhindi discusses the question whether contacts between Muslims and infidels are permissible. He refers to the tradition according to which the Prophet had a meal with a Jew and quotes the Qur'ānic verse which declares the food of the People of the Book lawful for Muslims. 21 He maintains that the impurity of the polytheists is not "essential" (najas-i •ayn); the verse saying that "the polytheists are impure" (innamā al-mushrikūn najas) ${ }^{22}$ indicates impurity of belief (khubth-i $i$ 'tigād) only. Sirhindi thus reaches the conclusion that contacts with the polytheists have never been forbidden and in the conditions of India are even inevitable. 23

Ikrām's contention that this letter reflects a more moderate attitude towards the Hindūs, adopted by Sirhindi at the end of his life, may be correct. The interpretation of 'AzIz Ahmad, who maintains that the letter was written to distinguish Sirhindi's "religiosocial separatism from Hindū caste-system ${ }^{24}$ also deserves careful consideration. However, another factor must not be lost sight of during our discussion of this apparent modification of Sirhindi's attitude towards the Hindūs. All the violent expressions of hostility against them in the first volume of the Maktūbāt are included in letters addressed to nobles of the Mughul court. Sirhindi's intention in these letters is to 
undermine the position of the Hindūs in the Mughul administration, rather than to fight their contacts with Muslims in other areas of life. 'Ihis intention is evident when due consideration is given to the identity of the recipients of these letters. 25 The absence of direct anti-Hind $\bar{u}$ material in the last two volumes of the Maktūbāt might, therefore, be due to the sharp decline in Sirhindi's correspondence with the ruling circles after the completion of the first volume. The letter on which Ikrām bases his contention is addressed to a șūfi, Maqşūd 'AlI Tibrīzi, 26 and views the question of polytheism and infidelity in an entirely different perspective. It seeks to assure the recipient that Muslims are not rendered impure by their inevitable contacts with the Hindūs, rather than to make a conciliatory move towards the latter community. Although the letter seems to imply that Hindūs may be considered as People of the Book, it does not indicate a change in Sirhindi's views on their participation in the Mughul administration.

To sum up: letters containing overt references to India and its Hindu inhabitants constitute only a tiny portion of the Maktūbāt. Most of them are addressed to officials of the Mughul court. It seems to us that SirhindI's view of the Hindūs - in the few cases when it 
is expressed - is determined not by the development of his ideas on the matter, but rather by the context in which it is expressed. Sirhindī objected to Hindū participation in the government; he therefore expresses his hostility towards Hindūs in letters to government officials who presumably had the power to purge the administration of Hind $\bar{u}$ influence. On the other hand, the few references to Hindūs in letters addressed to his fellow șüfis are relatively mild. 
CHAPTER VIII

\section{SIRHINDI AND THE MUGHUL COURT}

Whether Niuslim spiritual leaders should become involved in the administration of the state has been an issue since the earliest days of Islām. ' India has not been an exception in this respect. Professor Nizāmi has shown in his numerous articles on the subject that the șüfi orders active in India differed from each other in their respective attitudes to the rulers of the day. ${ }^{2}$ He maintains that "the Naqshbandi silsilah alone considered it not only permissible but imperative to establish contact with the rulers, and to attempt to influence their thought and policies". 3 It has been a near consensus of modern Muslim historiography that Sirhindi's revivalist activities, directed at the Mughul nobility and carried out in accordance with the general outlook of the Naqshbandi order, effected an important change in the direction of the Islamic developments in India. Sirhind $I$ is said to have been unanimously accepted as the mujaddid who "had restored the pristine purity of the doctrine of Islām" and paved the way for the gradual shift in the religious policy of the Nughul 
empire from the rank heresy of Akbar to the strict orthodoxy of Awrangzēb. He was able to achieve this result by exercising his influence on the ruling circles, not excluding the emperor Jahāngir himself. 4 We shall presently examine this opinion in view of the evidence available.

We must again stress at the outset that the relationship between religion and state is not one of the central themes in SirhindI's thought, and we have relatively few references to it in the Maktūbāt. As in other areas in this field, Sirhindi makes also statements that are seemingly contradictory. He objects when a șüf decides to join the services of the state; such an occupation Sirhindi considers worldly and therefore base. He himself, however, maintains correspondence with the ruling circles and demands that they seek the advice of the 'ulama'. This notwithstanding, he himself is not always enthusiastic about joining the court. It seems to us that in the beginning he preferred to exercise his influence by way of correspondence and that only later events, connected with his imprisonment, served to modify his attitude.

Historians who have dealt with SirhindI's attitude to the state have completely neglected those passages in the Maktūbāt in which Sirhindi sternly 
warns his correspondents against any connection with the rulers and their institutions. In the first volume we have a letter in which Sirhindi strongly advises one Bahā' al-Din against any association with the rulers. Faithful to the classical șūfi aversion to worldly affairs, he asserts that this world and the next are two irreconcilable opposites; one can be enjoyed only at the expense of the other. Speaking in the same vein, he quotes the following classical warning concerning the rulers: "Flee from their company more than you would flee from a lion; he causes (only) worldly death which might (even) be beneficial in the hereafter, while association with the kings necessarily brings about eternal perdition . . Beware of their company, beware of their food, beware of their love, beware of their sight . . " firra min suhbatihim akthar mimmā tafirr min al-asad fa-innahu ${ }^{5}$ yăjib al-mawt al-dunyawī wa-huwa gad yufīd fĩ al-ākhira wa-’khtilāt al-mulūk yūjib alhalāk al-abadī wa al-khasāra /sic/ al-sarmadī fa-iyyāka wa-suhbatahum wa-iyyāka wa lugmatahum ${ }^{6}$ wa-iyyāka wamahabbatahum wa-iyyāka wa-ru'yatahum).$^{7}$ Occasionally Sirhind $\bar{I}$ is even more specific. In a series of letters to Muhammad ȘiddĪq Badakhshİ, Sirhind $\bar{I}$ expresses his bitter disappointment that this promising disciple should have established contacts with the rich and 
finally joined the army, though he was in no material need. ${ }^{8}$ Mamrēz Khān Afghān, who also abandoned the șūfí way of life in order to join the armed services, deserves in Sirhindi's view only scorn and contempt; even if he reaches the rank of panj-hazārī or haft-hazārì, he had traded the ephemeral benefits of this world for the everlasting bliss of the hereafter. 9 As for the possibility that he himself might serve at the court, Sirhindi expresses different opinions. In a letter to Shaykh Farīd Bukhāri $i^{10}$ he indicates his willingness to assist Jahāngir in strengthening Islām; ${ }^{11}$ in a later letter to the same addressee, however, Sirhindi seems to be apprehensive that he may be asked to serve at JahāngIr's court in an advisory capacity. He expresses his apprehension in connection with the emperor's decision to invite four 'ulamā' to serve as shar'I advisors at the court. ${ }^{12}$ Sirhind $I$ is very pleased with this decision, though he would prefer that only one "sālim of the hereafter" (az "ulamā'-i ākhirat) be invited, to prevent wrangling. It is his hope, however, that he himself will not be asked to fill the post. 13

This material notwithstanding, Sirhind $\mathbf{I}$ maintained contact with various dignitaries of the Mughul empire and even received material support for his khāngāh from them. ${ }^{14}$ We shall presently analyse 
the part of the Maktūbāt containing this correspondence, while constantly keeping in mind that these letters constitute only a small portion of the collection as a whole. Not more than seventy letters out of the total 534 are addressed to persons who can be identified as servants of the emperor. Most of them are found in the first volume; of those only few deal with subjects that can be classified under the heading of religion and state.

We shall begin our discussion of Sirhindi's relations with the Mughul nobles and other influential people by an examination of a little known aspect of the subject. A few of Sirhindi's letters contain personal recommendations of various kinds. Some of the letters seem to have been written solely for this purpose, and the brief discourse on religious matters included in them serves only as a polite introduction to the main part of the letter. A few examples will illustrate the nature of the personal matters in which SirhindI tries to intervene. In a letter to Khwāja Jahān, Sirhindī requests him to release a prisoner who approached Sirhind $\bar{I}$ in this matter. ${ }^{15}$ Elsewhere he recommends two persons to the service of Jabārī Khān. 16 In other letters he requests that a certain learned man be given a governmental post ${ }^{17}$ or tries to obtain a 
stipend for the father of a large family who had to join the army because of his destitution. 18 In a letter to Shaykh Farīd Bukhārī, Sirhindi expresses the hope that a certain Shaykh Zakariyya will again be included in the diwān, apparently as a recipient of a stipend. 19 In two letters sent to his teacher al-BāqI bi-'Ilāh he seems to perform the function of a public notary in Sirhind. He certifies that certain persons eligible for government pensions are alive and asks that the sums be given to the bearers of the letters. 20 In none of these instances do we know whether Sirhindi's recommenations were heeded or not. 'there is, however, a partial answer to this question in another case. In a letter to Shaykh Farĩd Bukhārī Sirhindi complains that the city of Sirhind does not have a gādI and people are therefore compellcd to act unlawfully in certain cases. This situation would not arise if the vacancy were filled. 21 That this request of Sirhindi was not promptly complied with is clear from a letter written later on to Sadr-i Jahān. In it, Sirhind $\bar{i}$ speaks of the necessity to appoint judges in Islamic cities, complains that the city of Sirhind has not had a gādị ror several years, and requests that a protégé of his be appointed to the post. 22 Thus it seems that Sirhindi was ignored here in a relatively 
important matter.

These letters of recommendation must have been prepared for the persons concerned at their own request and were to be delivered by them to the prospective benefactors. The fact that Sirhindi was asked to write these letters indicates that he was believed to wield some influence upon the ruling circles of the capital, at least in questions of a minor, personal nature. However, more material will have to be discovered and analysed before it can be determined to what extent this belief was justified.

The most important documents for the evaluation of Sirhindi's historical role have been those few letters to the Mughul officials, in which he expresses his views on the situation of Islām in India during the reign of Akbar and Jahāngİr. His view of the decline of Islām during Akbar's period and his rejoicing at the accession of Jahāngir are too well known to need any detailed description. He bemoans the ascendancy of infidelity during the reign of Akbar and demands that Jahāngir be prevailed upon by his ministers to forbid the heretical customs that have established themselves at the court. He lays much of the blame at the door of the wicked,

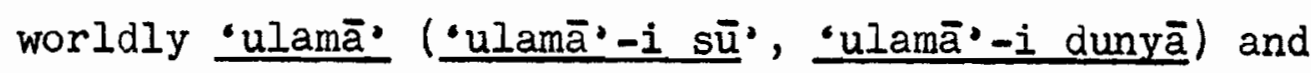
demands that the "ulamā' of the hereafter" (culama $\bar{a}^{\prime}-i$ 
akkhirat) assist the emperor in strengthening Islām.23

It is evident from the existence of these letters, that Sirhindi tried to impress his view of Isläm upon some of the top officials of the Mughul empire. Unfortunately, we do not have at our disposal the answers given to Sirhindī by these officials. We therefore cannot know to what extent his efforts were successful. His sweeping recommendations concerning the Hindūs were clearly not carried out by Jahāngīr, but this does not mean that his views failed to gain favour among some of the officials whom he contacted. 24 That the question of Sirhindi's influence upon the thinking of Shaykh Farĩd Bukhārī or 'Abd al-Rabīm Khān-i Khānān25 should have become a matter of controversy among the students of his works is regrettable; any opinion concerning the matter cannot escape from the realm of speculation till hitherto unknown material - hopefully the letters of these officials to SirhindI - is brought to light and analysed. 26 As the source material stands now, we cannot go beyond saying that Sirhindi tried, with unknown results, to propagate his ideas among the top echelons of Mughul officialdom.

Let us turn now to a discussion of Sirhindi's relations with Jahāngīr, which have also been a controversial issue among the students of the period. The 
view which asserts that "SirhindI. . did play some role in the accession of Jahāng İr"27 and that Jahāngīr, under the influence of Shaykh Farīd Bukhārī and Sirhindī, gave at the time of his elevation to the throne a pledge to defend Islām, 28 has been called seriously into question recently by the works of Habī 29 and Riźvĩ.30 It is true that Sirhindi expressed satisfaction at the accession of Jahāngīr, but later he was disappointed with the new emperor. His description of the situation of Islām during the reign of JahāngĪr, written between $1025 / 1616-7$ and $1028 / 1618-9,31$ is as gloomy as his descriptions of the period of Akbar. In a letter to Mİr Muhammad Nu'mān, Sirhindī says: "In your letter you spoke about the good character and piety of the present Sulțān and indicated that justice prevails and that the ordinances of the sharía are being compiled with. Perusal of this letter was for me a cause of great joy and pleasure. May God grant victory and grandeur to the shari'a of Muhammad and his community, just as he made the world resplendent with the brilliance of the present king's justice and equity! Dear friend! The spread of the illustrious shari'a depends, according to (the maxim) "the shar. is under the sword" (al-shar" taht al-sayf), upon the assistance and care of the great Sulțāns. This (assistance) has slackened recently and 
Islām has necessarily become weak. The Indian infidels fearlessly destroy mosques and erect temples in their

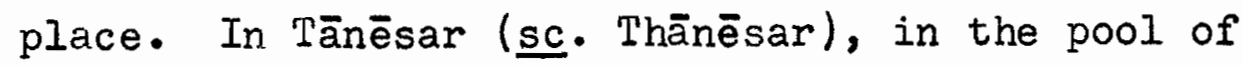
Kurukhēt (sc. Kurukshetra), 32 there was a mosque and a tomb of a saint. They destroyed these and erected a big idol-temple in their stead. The infidels publicly observe the customs of infidelity, while Muslims are unable to comply with most Islamic ordinances. On the day of Ekādashi $\bar{i}^{33}$ of the Hiridūs, when they refrain from eating and drinking, they insist that no Muslim bake and sell bread - in the country of Islām!; on the other hand, during the blessed month of Ramaḍan they cook and sell food publicly. Due to the weakness of Islām nobody can restrain them from doing this. Alas, a thousand times alas! The present king is one of us, and

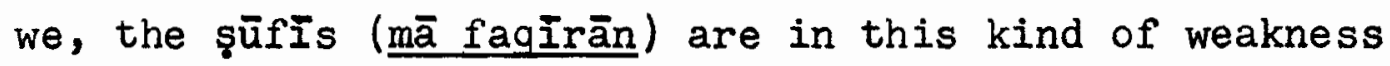
and misery 1 " 34

This passage makes it abundantly clear, that even if JahāngIr gave his alleged pledge to defend Islām, he did not honour it to Sirhindi's satisfaction. In 1619, not a long time after he wrote the letter which we have just discussed, Sirhindi was summoned to Jahāngİr's presence. His audience with the emperor and his subsequent imprisonment have been subject to numerous interpretations. The sources on which 
these interpretations are based can be divided into two distinct groups. One includes the memoirs of Jahāngīr and the Maktūbāt; the other consists of later Naqshbandi literature. While the former group is by virtue of its contemporaneity and authenticity historically far more important, it has been the latter one which contributed most of the material to the prevalent image of Sirhindi as the man who brought the Mughul dynasty back into the fold of Islām. We shall discuss this latter group of sources while dealing with the development of Sirhindi's image in Indian Muslim literature. Jahāngīr's memoirs contain three references to Sirhindī. In the first, JahāngIr describes Sirhindi as an arrogant impostor, who is sending his disciples to every town and city to deceive the people. Out of the idle tales that he wrote for his followers he compiled a book called the Maktūbāt, which contains many useless theories and leads people to heresy. Among other things Sirhindi wrote that he had transcended the spiritual stage of the khulafā-i rāshidūn. 35 Jahāngīr therefore summoned Sirhindi to the imperial court. Sirhindi behaved there in an arrogant manner, yet was not able to give any satisfactory explanations for his theories. Jahāngir continues: "I came to see that the best thing for him would be to be imprisoned for some time, so that 
his disturbed disposition and confused mind calm down a little and the agitation of the masses subside. He was taken into custody by Ani Rai Singh Dalan, to be kept imprisoned in the fort of Gawāliyār."136 About one year later Jahāngīr released him, gave him a robe of honour, and a present of one thousand rupees. He was given the choice of staying at the court or leaving it. He recognized that the punishment imposed upon him was an appropriate one. 37 In a subsequent passage Jahāngīr mentions that he gave Sirhindi a gift of two thousand rupees at his annual weighing ceremony. 38 Nowhere does JahāngĪr acknowledge that Sirhind $\bar{I}$ exercised any influence upon him.

Sirhindi refers to his imprisonment and his subsequent stay in the emperor's camp several times. It is clear that some letters in the first part of the third volume were written while Sirhindi was in Gawāliyār. He tends to see the episode in characteristically șüfi terms. The imprisonment is in his eyes a manifestation of God's awe (jalāl), as distinguished from His beauty (jamāl). Sirhindi feels that he has made great strides in his spiritual progress by experiencing both aspects of the Divine. ${ }^{39}$ He chastises one of his disciples who wrote that his own spiritual progress was adversely affected by Sirhindi's imprisonment. His 
suffering, and the contempt consequently shown to his disciples by the masses, should have an opposite effect: "the cruelty of the Beloved gives more pleasure than His fidelity" (jafā-yi mahbūb az wafā-yi $\bar{u}$ bishtar ladhdhat bakhsh ast) .40 Sirhindi does not see his imprisonment as a part of a struggle against the emperor or his policies. He sees it entirely in terms of șūi experience.

As for his stay at the royal camp, Sirhindi seems to have enjoyed it; 41 however, while describing the end of his stay there he says that he "was freed by divine providence from accompanying the army". 42

As the source material stands now, it is difficult to establish satisfactorily the reasons behind Sirhindi's imprisonment. Jahāngir himself speaks of Sirhindi's arrogant claims to spiritual eminence and mentions, very vaguely, an "agitation of the masses" which he wants to stop by Sirhindi's detention. Though there is no compelling reason to doubt Jahāngin's explanation of the action he took against Sirhindi, some writers tend to think that it is not satisfactory. Nür Jahān's irritation at Sirhindi''s attacks against the ShI $\cdot a h$ and his failure to perform prostration in the emperor's presence were cited as the real reasons for his imprisonment. This may be so; but since neither of 
these elements can be satisfactorily established by sound historical method, we prefer to treat them as a part of Sirhindi's image as it developed in Indian Muslim literature. 43 We shall refer to them again in due course.

After his release from prison, Sirhindi wrote one letter to Jahāngīr. He wishes success to the imperial armies and then proceeds to apply the șufi dichotomy of form (șūra) and essence (hagīga) to military affairs. He makes a distinction between "formal victory" (șūrat-i fath), which can be achieved by the "army of war" (lashkar-i ghazā) and "real victory" (hagĩgat-i fath) which can be achieved by "the army of prayer" (lashkar-i du' $\left.\overline{\mathrm{a}}^{\cdot}\right)$. He has no doubt in his mind that the army of prayer is the stronger one, because prayer, not the sword, is the only way to avert the divine decree. 44

In another letter, addressed to his sons, Sirhindi describes a meeting which he had with the emperor. He explained to the emperor the basic principles of Islām, did not make any compromise and used the same language he employed in the șufi gatherings. The emperor is said to have listened attentively, without any sign of disapproval. 45 The emperor's apparent agreement with Sirhindi's discourse is, however, less significant than 
it seems to be, because Sirhindi apparently did not expound his controversial views on this occasion. He spoke about "the mission of the Prophets, the insufficiency of reason, the belief in the hereafter, reward and punishment, the affirmation of the Vision, the finality of Muhammad!s prophecy, the centennial mujaddids, emulation of the khulaf $\bar{a}^{\circ}-i$ rāshidun, the sunna of the tarāwin (prayers), the falsity of the transmigration of souls, the conditions of the jinn and their reward and punishment and so on". 46 sirhindi did not offer to the emperor any advice as to the proper conduct of political affairs, and least of all did he urge him to purge the administration of Hindu influence or to impose jizya on his Hindū subjects. It is clear that in the primary sources from which we have to draw our information about Sirhindi's relationship with Jahāngīr, there is little material to substantiate the thesis that Sirhindi succeeded in converting the emperor to his view of Islām. 


\section{CHAPIER IX}

\section{THE JUDGNENT OF POSTERITY}

In the preceding chapters we have outlined the thought of Shaykh Ahmad Sirhindi. It is time now to discuss the view taken of him by his contemporaries and by subsequent generations. The opinion that Sirhindi was recognized by the ijjmä of Islām in India as the Renewer of the Second Villennium has been widely accepted by Muslim historiography and followed by some western scholars. Sirhindi's admirers were able to sustain it by ignoring or explaining away a whole body of material reflecting a different point of view. It is our contention that the consensus of the Muslims of the subcontinent concerning Sirhindi's historical role is of late origin and is now showing signs of breaking down. The purpose of this chapter is to trace the changing image of Ahmad Sirhindi in Indian Muslim literature from the seventeenth century to the present day. Clearly not all the relevant works could be discussed here and we do not claim to have exhausted the subject. Especially the nineteenth century literature is inadequately represented. Nevertheless, a reasonably clear development of Sirhindī's image will be discernible in our discussion. 
1. 'Abd al-Haqq Muhaddith Dihlawi and 'Abd al-Jalil Siddígi.

The image of Sirhind $\bar{I}$ in the eyes of his contemporaries could be best ascertained on the basis of letters which he received from his correspondents. These were undoubtedly numerous. Sirhindi's replies and the editors' brief introductions to them occasionally contain references to the reactions aroused by Sirhindi's views. Apparently he was questioned several times in connection with letter 11 of the first volume, in which he described his spiritual ascent and seemed to imply his superiority to $A b \bar{u} B a k r .{ }^{I}$ Elsewhere he states that some of his disciples did not abandon practices of which he disapproved ${ }^{2}$ or even left the țariga. ${ }^{3}$ This material is, however, patently insufficient to assess the reception of Sirhindi's ideas among his contemporaries. An adequate assessment could be made only by studying the full texts of letters received by Sirhindi. Only two such letters have come to light thus far. The more important of them is by the famous writer "Abd al-Haqq Muhaddith Dihlawī and was discovered by Professor Nizāmi. 4 The other is a hitherto unknown letter by "Abd al-Jalīl ȘiddīqI preserved in the Khudā Bakhsh Library in Patna. 5 These letters, and especially the former, set the tone for the discussion of Sirhindi's views in later literature. 
-Abd al-Haqq opens his letter very respectfully. He points out that for years on end he has been anxious to ask Sirhindi to explain some of the statements made in the Maktūbāt. 6 Among the statements that have made people uneasy and puzzled he mentions Sirhindi's view that $A b \bar{u}$ Yazīd al-Bisțāmī and al-Junayd remained "captivated by the shadow" (giriftār-i zill) and never reached the essence (aşl). Sirhindī's claim that he was the first to receive certain spiritual insights and his discourtesy towards his teacher al-Bāqī bi-'llāh and other great şüfis were also found objectionable. Furthermore, Sirhind $\bar{I}$ claimed that the perfections of Muhammad and Ibrāhīm combined in his personality, that he had been created from the remnants of the clay used in the creation of Muhammad, 7 and that all the perfections which were originally (bi-Pl-așāla) invested in the Prophet were eventually given to him as Muhammad's follower (bi-tatabbu" wa tufayl /sic/ ).8 "Abd al-Haqq was willing to overlook alı these. However, when Sirhindi wrote letter 87 of the third volume, "Abd alHaqq was unable longer to restrain himself. He quotes the controversial letter in full, ${ }^{9}$ then censures the arrogance implicit in it and castigates Sirhindi for want of humility which is the essence of the șüfi ideal (darwīshĩ). Sirhindi''s attitude is in 'Abd al- 
Haqq's view unprecedented; indeed, there were arrogant șüfis in the past, but they were careful to exclude the Prophet from their claim to superiority. Commenting on Sirhindi's statement that he is "sharing in the wealth" (. . sharīk-i dawlatam), 10 'Abd al-Haqq rejects Sirhindi's distinction between the sharing of equals and sharing which does not imply equality: sharing (shirka) and equality (ham-sari) are in his view identical, and there can be no sharing between servant and master. Sirhind $\bar{i}$ thus makes a false claim of equality with the Prophet. 11 'Abd al-Haqq compares Sirhindi's attitude with that of some Mahdawis: they claim that Sayyid Muhammad Jawnpūri acquired all the perfections of the Prophet by faithfully following him; this is exactly the attitude adopted by Sirhindi regarding himself. Sirhindi's doctrine is also analogous to the attitudes of the ShI'a who claim that the twelve a'imma are the Prophet's disciples who reached the rank of their master. ${ }^{12}$ Sirhindi's statements are, in 'Abd al-Haqq's view, self-contradictory: it is meaningless to say that "I am a parasite, yet have not come uninvited"; a parasite is precisely the man who comes to a feast uninvited. It is similarly meaningless to state that "though I am a follower, I am not without a share of genuineness", or that "I am both the disciple of God 
(murīd allāh) and His desire (murād allāh)". The proper belief is that all are the disciples of Mubammad, and he alone is the disciple of God who receives from Him the blessings and transmits them to the community. A Muslim bristles with horror at statements of the kind that Sirhindi made. 13

The rest of the epistle is devoted to a detailed refutation of Sirhindi's views as expressed in the letter under consideration. Sirhindi's claim that there is no mediation between himself and God comes in for the severest criticism. Illustrating his view by the verse "be ecstatic with God, but sober with Muhammad"

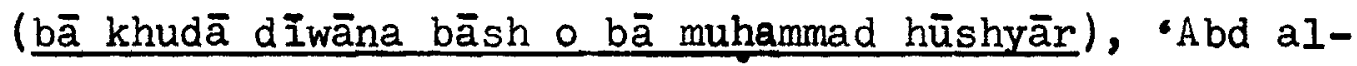
Haqq maintains that this claim entails gross discourtesy towards the Prophet. He stresses that his appreciation of Sirhindi and of his way in taşawwuf is still very high, but he could not remain silent in view of Sirhindi's statements regarding the Prophet. 'Abd al-Haqq indicates that he has taken this critical stand only after the most careful consideration of the matter. At the end of the epistle he prays, asking God to show him the right way if his criticism is unjustified, and to guide Sirhindi to the right path if it is he who is in error. ${ }^{14}$ The disagreement between Sirhindi and 'Abd alHaqq has been a source of embarrassment for the Naqshbandis, 
who have tried to demonstrate the unanimous acceptance of Sirhindi by his contemporaries. Several traditions, intended to minimize or explain away the disagreement between the two thinkers, have come into being. According to some of them, "Abd al-Haqq wrote his critique on the basis of spurious letters circulated with malicious intent by an enemy of Sirhindī, Hasan Khān Afghān. The conspiracy was discovered when Sirhind I sent to "Abd alHaqq the genuine version of his letters, whereupon "Abd al-Haqq apologized to Sirhindi for his attack. ${ }^{15}$ This tradition is, however, baseless. The genuineness of the letter which aroused 'Abd al-Haqq's criticism is beyond question, since Sirhindi himself, in his reply to 'Abd al-Haqq, accepts the responsibility for writing it and attempts to explain it in a way not incompatible with proper Islamic belief. ${ }^{16}$ Some Mujaddidis tried to minimize the importance of 'Abd al-Haqq's opposition to Sirhindi by saying that he was a bigot, belonged to the "superficial" 'ulamā' ("ulamā'-i zawāhir), and spoke on the basis of unfounded rumours. In their view no importance ought to be attached to disputes between contemporaries which are presumably based on personal rivalry. 17 In any case, "Abd al-Haqq is said to have eventually retracted his criticism in a letter to Ḥisām al-Din Ahumad. ${ }^{18}$ The letter is given at the end of an 
account of Sirhindi's teaching which constitutes an appendix to the printed editions of 'Abd al-Haqq's Akhbār al-Akhyār. ${ }^{19}$ Its authenticity is, however, open to question. The entire appendix does not appear in the oldest manuscripts of the book 20 and seems to have originated in late Mujaddidi circles. 21

Whether 'Abd al-Haqq eventually retracted completely his criticism of Sirhindi or not, the two thinkers retained their mutual respect despite their disagreement. 22 While 'Abd al-Haqq certainly criticized some of the fundamental aspects of Sirhindi's teaching, his criticism has nothing of the acrimony that is characteristic of the polemical works written against Sirhindi in the late 17th century •

-Abd al-Jalil Șiddĩq from a different angle. While Abd al-Haqq accused him of transgressing the limits of propriety in his remarks about the Prophet, 'Abd al-Jalil implies that Sirhindi's understanding of the nature of God and the world is not sufficient and that he is merely one of the "superficial" 'ulamā.. 'Abd al-Jalil's short letter is apparently a reply to letter 112 of the first volume of the Maktūbāt. Sirhindi stresses in this letter the paramount importance of the beliefs of ahl al-sunna wa al-jamāa. If one has acquired these beliefs, says Sirhindi, he can dispense with any șūfi experience; on the other hand, șūfí 
experience that is incompatible with them is nothing but satanic temptation (istidrāj). He also contrasts the infallibility of Prophecy with the fallibility of șūfĩ experience. ${ }^{23}$ Abd al-Jalil opens his reply by saying that whoever understands properly the meaning of lāilāh illā 'Ilāh is relieved from the distinction between reward and punishment which depend upon duality $\left(\underline{d \bar{u}^{2}} \bar{I}\right)$; once the duality is removed, reward and punishment disappear along with it. The only thing that remains then is the Beauty of Unity (jamāl-i tawhidd), as indicated in the Qur'anic verse: "He is God, the One". The Knowers of Truth ("ulamā-i hagIgat) consider existence as one. It is only the superficial 'ulamā' ('ulamā'-i zawāhir) who dwell upon Custom (sunna) and Community (jamā'a); the Knowers of Truth have made Union (jam-iyya) the center of their lives. There can be no Community there is only Prophecy. The Prophet said: "A shaykh in his group is like a Prophet in his community" (al-shaykh fi qawmihi ka-'l-nabi fi ummatihi). But Prophecy brings with it only uncertainty (taraddud),

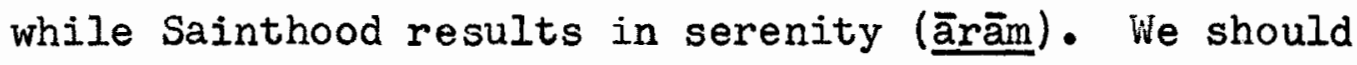
not lapse from serenity to uncertainty because it will not make any change in the House of Divinity. One hundred and twenty four thousand Prophets have been sent to the world, but none of them has made any change there. The 
situation remains the same to this day (al-ān kamā kān ast). Since the death of Muhammad, Sainthood has been superior to Prophecy. 24

The two letters analysed here are obviously insufficient to allow a comprehensive assessment of the contemporary reaction to Sirhindi's views. They may, however, be indicative of two groups of persons who were dissatisfied with the contents of the Maktūbāt. "Abd alHaqq represents those who resented Sirhindi's extravagance, his excessive self-esteem and his allegedly derogatory remarks about the Prophet. They saw in all this a deviation from the accepted sunna of the community. "Abd al-Jalil, on the other hand, speaks for those who had little use for religious observance and regarded the personal experience of Union as the highest spiritual achievement. They saw in Sirhindi's stress on custom (sunna) and community (jamāea) an indication that he had failed to transcend the formal aspects of religion and was unable to reach the ultimate religious truth. Sirhindi seems to have antagonized both groups. On the basis of the material now available, it is impossible to assess the importance of these two groups in the community as a whole. More material will have to be brought to light before the degree to which Sirhindi's views made an impact on his contemporaries can be reliably determined. 
Sirhindi's widespread correspondence would indicate, however, that many people sought to learn from him the science of tasawwuf, despite the opposition that he encountered from the "ulamā' and some şüfis.

2. The hagiographic literature.

The hagiographic literature $e^{25}$ is concerned primarily with the miracles Sirhindi was believed to have performed. Although Sirhindi stresses several times in the Maktūbāt that miracles are not a necessary part of șūfi activity, ${ }^{26}$ among his followers the legend of an all-powerful miracle worker soon came into being. The hagiographies contain traditions according to which the coming of Sirhindi was predicted by such eminent șūfis as Aḥmad-i Jām. 27 They credited Sirhindi with the miraculous ability of healing the sick, ${ }^{28}$ preventing disasters, $^{29}$ rescuing people who had lost their way in the desert, ${ }^{30}$ discovering people's hidden thoughts and practices $^{31}$ or being able to appear in different places at the same time. ${ }^{32}$ Sirhindi's prayer at a funeral is capable of bringing forgiveness to the deceased and of abrogating the punishment of the grave. ${ }^{33}$ A distinct group of stories deals with Sirhindi's violent treatment of persons who slighted him or honoured those who had fallen out of grace with him. 34 of particular interest is a miracle story connected with the destruction of a 
Hindū temple. A group of Sirhindi's disciples was engaged in the destruction of a temple in the Dakhan in accordance with their master's teaching. When they were surprised by a large number of infidels, Sirhindi miraculously brought a Muslim force to their rescue. 35 This story is a faint indication that Sirhindi's views on the Hindūs began to filter down to the popular level. One should, however, keep in mind that this is the only story of its kind in the hagiographies which we have examined. Sirhindi's image in the eyes of his disciples was by no means that of a fanatic iconoclast, but rather that of a saint endowed with diverse miraculous powers. The significance of the above-mentioned story should not be exaggerated. 36

The hagiographic literature is also the main source for material relating to Sirhindi's alleged influence on Jahāngİr and for the Naqshbandī version of the events leading to Sirhindi's imprisonment. SirhindI is credited with miraculously preventing the Sulțān from wreaking his vengeance on delinquent officials of the court and with bringing about the dismissal of an unjust governor. 37 He also predicts that Shaykh Farid Bukhārī will be unsuccessful in his attempt to conquer the Hindu fortress of Kāngra. ${ }^{38}$ Rather unwillingly he later gives his blessing to Bikramājīt, the Hindū 
commander of the new and successful expedition against the fort. 39

Sirhindi's imprisonment according to the hagiographic literature was the result of a $\operatorname{sh} \bar{i} \mathbf{I}$ conspiracy against him. Sirhindi was summoned to the court and asked about his alleged claim to have surpassed the spiritual achievements of Abu Bakr. He replied to the charges. The reply satisfied the emperor, and Sirhind $I$ was excused. However, when the shi' $\bar{I}$ conspirators saw that their plot was failing, they drew the emperor's attention to the fact that Sirhindi had failed to perform the sajda. He was recalled and ordered to prostrate. He refused to do so and was sent to prison where he spent his time studying the Qur'ān and converting his fellow prisoners to Islām. 40 Prince Khurram, whose ultimate victory in the struggle for the throne was predicted by Sirhind $\bar{I}, 41$ sent two fuqahä. to Sirhind $I$ in order to persuade him that prostration before a ruler is permissible. He should perform it and forego further punishment. Sirhindi refused. In his view prostration before anyone except God was unlawful. 42 The emperor finally repented, released Sirhindi, honoured him and never again parted company with him. Shāh Jahān, Awrangzēb and all their tulamāo and wuzarā. became members of the Mujaddidi order. 43 Sirhindi's unyielding 
attitude and defiance in the face of un-Islamic practices have subsequently become a major component of his modern image.

3. The controversy over Sirhindi during the reign of Awrangzèb.

The polemics over Sirhindi's views, touched off by the letter of Shaykh 'Abd al-Haqq, seems to have subsided after Sirhindi's death in 1624. SirhindI replied to 'Abd al-Haqq shortly before that date, and -Abd al-Haqq was unable for that reason to resume the debate even if he did not find Sirhindi's explanations satisfactory. The decades imnediately following Sirhindi's death were characterized, as far as literature regarding him is concerned, by hagiographies written by Sirhindi's immediate disciples. As could be expected, these depicted Sirhindi in a very favourable light. Polemics came into prominence again during the reign of Awrangzēb.

On Shawwāl 27,1090/December 1, 1679 the shaykh al-islām, acting upon the instructions of the emperor, issued a decree of considerable importance for the evaluation of Sirhindi's historical role. The decree was sent to the gādI of Awrangābād whose name was Hidāyat Allāh. Its main part reads as follows: "It has reached this august and holy location that some passages in the 
Maktūbāt of Shaykh Aḥmad Sirhind I are apparently opposed to the views of ahl al-sunna wa al-jamā'a. The followers of the above-mentioned shaykh, who have established their residence in the happy city of Awrangābād and are very active in spreading and teaching these (Maktūbāt), maintain that the false ideas mentioned above are true. Therefore the following exalted order has found the honour of being issued: this servant of the shari'a (i.e., the shaykh al-islām) writes to the refuge of the shari'a (i.e., the qādi of Awrangābād) to curb them from teaching this. Should it become known that anybody believes in the above-mentioned false ideas, let him be punished by the shar'i punishment." 44 As for the authenticity of this document, there is no reason to doubt it. Ma‘ārijal-Wilāya, the work in which it is included, was completed only four years after the date of the decree under consideration and was written in the city of Awrangābād. 45 The reliability of the decree as an historically authentic document is greatly enhanced by the fact that it appears in a contemporary work written in the same city to which the decree was originally dispatched. The existence of the decree is mentioned in two additional contemporary works. ${ }^{46}$ Moreover, the supporters of Sirhindi in the controversy that ensued never denied its existence and 
never declared it to be a forgery.

Quşūri, the author of Ma‘ārij al-Wilāya, says

in the beginning of the chapter devoted to Sirhindi that he is favourably inclined to the şüfis. As an indication of his impartiality, he promises to quote Sirhindi's ecstatic statements (shathiyyāt) before reproducing the hostile fatāwā of his opponents. 47 His quotations are by and large accurate. ${ }^{48}$ After quoting a large number of fatāwā declaring Sirhind $\bar{I}$ an infidel, 49 he says that these are valid only if Sirhind $\bar{I}$ wrote his ecstatic discourses with their external (zāhir) meaning in mind; if he intended them to be understood in the internal (bātin) sense, he is not to blame, though he should not have made statements disrespectful of the Prophet. 50 Thus, there is no reason to fear that Qușūri would have introduced into his book a spurious document because of personal hostility to Sirhindi. It is true that he does not offer detailed argument in defense of Sirhindi, but this in itself is a powerful indication of the view prevailing in the late seventeenth century. We can safely assume that few people then alive were surprised when the decree proscribing the Maktübāt was published.

Qușūri maintains that the 'ulamā' were hostile to Sirhind I mainly because of the letters dealing with 
the Millennium and with the relationship between Nuhammad and Ibrāhİm. 51 He then gives extensive quotations from a book called Kāsir al-Mukhālifin. The author of this book, whose name is not given by Qușüri, objects to Sirhindi on similar grounds. Sirhindi's views on the Millennium in the author's opinion imply that both Ibrāhim and the "common believer" are superior to Muhammad. 52 Sirhindi had said that Muhammad had not reached the highest stage of spiritual development before the advent of the Willennium; this view is contrary to the Qur'ān, the sunna and the ijmā.. 53 Sirhindi is in this author's view a self-conceited (khwud-ra'y), opiniated (khwud-pasand), arrogant (hwud-bin) and ignorant ( $\underline{\bar{a}}$ dānishmand) person who doubtlessly considers himself the "common believer" with a crucial spiritual task. 54 It is a consensus of the community that haqIgat-i muhammadi is the highest haqIqa; it is superior to all other hagà'ig and called therefore hagiqat albagā'ig. Sirhind's theory that haqIqat-i ka'ba is higher than hagiqat-i muhammadi and his description of the changes that take place in the respective positions of the various haqa'iq with the advent of the Millennium must therefore be rejected. 55 Kāsir al-Mukhālifin then criticizes Sirhindi's pretenses in the controversial letter 11 of the first volume, 56 censures Sirhindi for divulging 
the secrets of his mystical experiences, 57 and flatly accuses him of claiming to be a Prophet. ${ }^{58}$ QușürI then quotes several fatāwā declaring SirhindI an infidel. These fatāwā were the background against which the decree proscribing the Maktūbat was issued. 59 The controversy over SirhindI did not subside with the issuance of Awrangzēb's decree. The decree was apparently unsuccessful in curbing the teaching of the Maktūbāt to the satisfaction of SirhindI's opponents. They continued in their efforts to strengthen their position and approached the prestigious eulama' of alHija $\bar{z}$ with a request for an opinion on the matter. The original text of the istifta.', which reached al-Hijāz in Jumādā II, 1093/June-July 1682, has not yet been brought to light, and the identity of its authors remains uncertain; however, it is mentioned several times in the contemporary literature and extensively quoted in Attivyat al-Wahhāb by Muhammad Bēg al-Uzbaki. ${ }^{60}$ The charges made in the istifta. are similar to those made

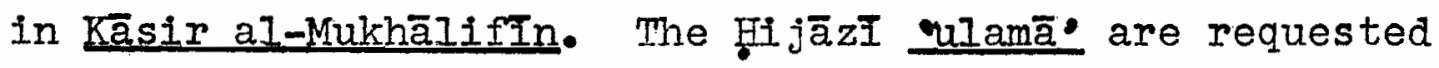
to state their opinion with respect to the following main points: the superiority of hagIqat-i ka ba to hagIqat-i muhammadI; ${ }^{61}$ the special status of the "yommon believer"'; ${ }^{62}$ letter 87 of the third volume; ${ }^{63}$ Sirhindi's alleged claim to have been created from the remnants of 
the clay used in the creation of Muhammad; ${ }^{64}$ his claim that his wilāya is compounded from the wilāyāt of Mūsā and Ibrāhim; ${ }^{65}$ the disappearance of Muhammad's bodily aspects and the reappearance of the prophetic perfections with the advent of the Millennium; ${ }^{66}$ letter 11 of the first volume. $67^{\prime}$ According to Muhammad Bēg's account, the istifta. contained, in all, questions on 32 points in Sirhindi's teaching. It was written in Arabic.

The response of the Hijāzì 'ulamā' was swift. Muhammad b. 'Abd al-Rasūl al-Barzanji completed his Qadh al-Zand not more than a month after the istiftà had been received. At about the same time Hasan b. 'Ali wrote his al-'Asab al-Hindī. $68 \mathrm{Sa}$ 'Id b. Barakāt, the sharif of Makka, sent both books, together with other material of similar nature, to the "qādi of India" (gādi al-hind). Accompanying the books was a letter of his own, in which he states that the "ulamā of al-Hijāz had unanimously decided that SirhindI was an infidel. Any other opinion should be discarded. 69

Al-Barzanjī begins his Qadh_al-Zand with a reference to the above-mentioned decree of Awrangzēb.70 He then gives a lengthy exposition of his views of the Prophet. Muhammad is the best of creatures and did not leave this world without first realizing in himself all 
possible perfections. ${ }^{71}$ Sirhindi is, therefore, patently wrong when he says that the $\mathrm{Ka}$ "ba is superior to the Prophet. ${ }^{72}$ Similarly, it is indefensible and preposterous to maintain that the Prophet reached perfection only a thousand years after his death. Al-Barzanji is the first critic to say explicitly that Sirhindi's theory of the hagigat-i muhammadi changing to hagigat-i ahmadi is a thinly veiled hint at his own person. Like the author of Kāsir al-Mukhālifing, he flatly accuses Sirhindi of claiming to be a Prophet. The desire to uphold this claim is the reason that Sirhind $\mathrm{I}$ called himself the Renewer of the Second Millennium and said that the Prophet Muhammad disappeared while he himself was sent to guard and preserve the community. 73 With caustic sarcasm al-Barzanji says: "I wish I knew who is guarding the community after his death more than sixty years; not even his name left India, let alone his guardianship and preservation!" (wa layta shi'ri man yahris al-umma ba'da mawtihi fa-gad māta mundhu sittina sana wa lam yakhruj dhihruhu an ard alhind fadlan an hirāsatihi wa hifzihi). 74 The bodies of the Frophets never decay or disintegrate; 75 it is therefore manifest infidelity (kufr sarāh) to maintain that the body of Mubammad disappeared a thousand years after his death.76 Al-Barzanji then assails the very 
concept of the Second Millennium by stating that it will not be allowed to run its course: "What is the meaning of the Renewer of the Second Millennium? Does a second millennium remain from the time allotted to this community so that he can be its Renewer? Did the 'ulamā. not agree unanimously and did al-hāfiz al-Suyūṭ not say in his epistle (called) al-Kashf 77 that not even five hundred years will elapse after the Millennium and that the Day of Resurrection will take place four hundred odd years after it? (mā ma 'nā mujaddid al-alf al-thānì wa hal bagiya min muddat hädhihi al-umma alf thānī /sic/ hattā yakūn mujaddidahu a laysa gad ajma'a al-'ulamā' wa dhakarahu al-hāfiz al-suyūt fi fi risālatihi al-kashf anna mā ba'da al-alf lā yablugh khams mi'a sana wa anna al-qiyāma taqūm fí arba'a mi'a wa shay'). ${ }^{78}$ Millennial renewal, unlike its centennial counterpart, has not been mentioned in the classical sources. Furthermore, it implies the abolition of Muhammad's prophecy and of his law. 79 The next point assailed by al-Barzanji is Sirhindi's claim to have direct relationship with God without prophetic mediation. ${ }^{80}$ Sirhindi's claim to have been created from the remnants of the clay used in the creation of Muhammad also comes in for criticism. 81 The millennial revival of prophetic perfections 82 and Sirhindi's claim of superiority to $A b \bar{u}$ Bakr ${ }^{83}$ are 
sharply attacked. Sirhindi cannot claim, says alBarzanji, that he spoke on the spur of the moment while being in the state of intoxication; he deliberately committed his ideas to writing and did not withdraw them even when cautioned and reprimanded by such eminent persons as Abd al-Haqq Muhaddith Dihlawi. No consideration can be shown to a person whose infidelity manifests itself in his disrespect for the Prophet. ${ }^{84}$

Neither Qadh al-Zand nor the very similar alAssab al-Hindĩ remained unchallenged for long. In fact, the letter of $\mathrm{Sa}$ 'Id $\mathrm{b}$. Barakāt which we have mentioned earlier contains strong indications that some of the Hijāzi "ulamā' did not agree with the condemnation of Sirhind $\bar{I}$ in the first place. After stating that the decision to declare SirhindI an infidel was unanimous, Sa'I d b. Barakāt says that those who expressed a different opinion were persons with insufficient knowledge although they occupy high positions. They should not be relied upon. 85 We can safely conclude from this statement that some highly placed 'ulamā' of al-Hijāz disagreed with al-Barzanji and Hasan b. 'AlI. But the major challenge to Sirhindi's detractors came from Muhammad Bēg al-0zbaki who came to al-Hijāz from India after al-Baranjī wrote Qadh_al-Zand. Shortly after his arrival Muhammad Bēg wrote 'Atiyyat al-Wabbāb al-Fāsila bayna al-Khata' wa al- 
Sawāb. 86 The main purpose of this book was to show that the fatāwā issued against Sirhindi were based on a faulty translation of his ivaktūbāt into Arabic and on wilful misrepresentation of his views. 87 several examples will demonstrate the method used by Muhammad Bēg in his defense of Sirhindi. In letter 87 of the third volume Sirhindi says: "Ihe chain of my discipleship is connected with God without mediation" (irādat-i man bi tawassut bi-'llāh muttasil ast). The Arabic translation by Sirhindi's rivals read: irādatī muttașila bi¿llāh min ghayr tawassut ahad. Muhammad Bēg translates: irādati muttașila ilā allāh ta ${ }^{\prime} \bar{a} l \bar{a}$ bi-lā wāsița. To this he adds: "meaning, without mediation except that of the Prophet" (ay bi-lā wāsita ghayr al-nabī). 88

This interpretation can hardly be justified if one keeps the original Persian text in mind. With regard to SirhindI's saying that "my path is the path of subhānī" (ṭarīga-yi man țarīqa -yi subhānī ast), Muhammad Bëg

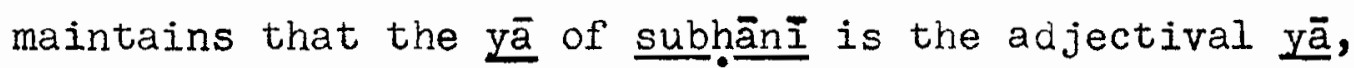
not the yāa denoting the first person. The Arabic translation of this phrase should therefore read: tarígi alțariqu al-subhānivyu (and not țarīgi țariqu subhānī). According to this interpretation, Sirhindi does not glorify himself by this expression, but rather says that his way is the way of those who say subhān allāh. 89 In 
many cases Muhammad Bēg simply denies that Sirhindĩ said the things attributed to him by his opponents. Elsewhere he disputes the interpretations given to Sirhindi's letters. For instance, he argues that one cannot conclude from letter 11 of the first volume that Sirhindi reached the high stages of spiritual achievement only in his capacity as a servant and because of his following of the Prophet. 90

Although most of Muhammad Bëg's translations and interpretations seem to be rather strained linguistically, he apparently succeeded in obtaining opinions favourable to Sirhindī from several 'ulamā'. He was assisted in his efforts by another şüfĩ from India, Jalāl al-Dīn al-Baṭḥī, and by Muhammad Farrukh Shāh, probably a grandson of Sirhindi.91 In addition to the preparation of a new Arabic version of Sirhindi's controversial letters, Muhammad Bēg defended SirhindI in debates with the Hijāzi 'ulamā'. These debates are mentioned by al-Barzanji in his al-Nāshira al-Nājira li1-Firqa al-Fājira, 92 which was written with the intention to counter to pro-Sirhind I campaign launched by Muhammad Bēg and to refute Sirhindi's views once again. AlBarzanji speaks of Muhammad Bēg with scorn and contempt, accuses him of gross ignorance of both Arabic and Persian, and considers him incompetent to engage in 
religious debates with the learned 'ulamā' of al-Hijāz.93 It seems to us, however, that the considerable attention given to Muhammad Bēg's activities by al-Barzanjī would indicate that Muhammad Bēg's campaign was making some headway • 4. Sirhindi's image in the seventeenth century.

The prevalent image of Shaykh Ahmad Sirhindi among the seventeenth century "ulama'. was that of an extravagant şūfi, suffering from illusions of grandeur and highly disrespectful of the Prophet. It was this image that prompted Awrangzēb to order the issuing of the decree proscribing the Maktūbāt and characterizing their contents as opposed to the views of ahl al-sunna wa al-jamäa. Thus, the view according to which Awrangzēb's religious reforms were inspired by the works of Abmad Sirhindi is no longer tenable, though Sirhind had, indeed, recommended some of the measures eventually implemented by Awrangzēb. The letters in which Sirhindi demanded the implementation of the shari.a by the state are not mentioned at all in the seventeenth century sources used in the preparation of this work. Such an omission is not surprising when made by SirhindI's critics; it is amazing, on the other hand, that Sirhindi's supporters, who barely held their ground against the vehement and well-documented attacks of 
their rivals, did not use these letters to bolster the image of Sirhindi as a pious sunnI Muslim. The crusading zeal permeating some of Sirhindi's letters to the Mughul officials might have had an enormous impact upon the Hijāzi 'ulamā'. Yet no use was made of this material by such a man as Muḥammad Bēg, who exerted a considerable effort to clear Sirhindi of the charges levelled against him. The fact that SirhindI's letters to the Mughul officials and his demands for the strict observance of the shari'a were virtually forgotten in the seventeenth century can be explained by several factors. It is likely that only a few complete collections of the Maktūbāt were available at the time. Individual letters were probably transmitted by the original recipients to their fellow sifuis, and it was in this way that the letters gained most of their publicity. 94 Sirhindi's demand for the strict implementation of the shari'a by the state was voiced exclusively in letters to Mughul officials which could not be spread in the way described above, and were therefore known only to their original recipients and to those few who possessed a complete collection of the Maktūbāt. As for the general exhortations to follow the shari'a, which are so common in Sirhindi's works, these were considered too commonplace to be of much value and are barely referred to by 
Muhammad Bēg. 95 Sirhindì was primarily a șūfī and had to be defended within a șūfĩ frame of reference. Muhammad Bēg had to show that Sirhindī's spiritual experiences, as described in the Maktūbāt and the other works, were not incompatible with the basic principles of Islām. Sirhindi's personal observance of the shari'a and his demand that others do likewise were irrelevant in the controversies of the seventeenth century. Unlike the 'ulamà', the historians of the period do not seem to have devoted much attention to Sirhindī. The Tiabaqāt-i Shāhjahān̄̄ by Muhammad Șādiq, a major collection of biographies written in midseventeenth century, has only a short note on Sirhindi and says that "he was one of the successors of the renewer of the Naqshbandī order (?), Khwāja Muhammad BāqI Naqshbandi Uwaysĩ . . He was knowledgeable and observant, a sea of divine secrets. He is the author of valuable books. His books and letters contain many curiosities and strange things which (even) the intellects of the wise people are unable to comprehend. He died at the end of Safar of the year 1034 and was survived by knowledgeable, observant and talented sons." (azkhulafā'-i mujaddid-i tarīga-yi nagshbandiyya khwā,ja muhammad bāqĩ naqshbandi uwaysi ast quddisa sirruhu tālim o 'āmil wa babr-i asrār-i ilāhī būd wa sāhib-i taşānīf-i ‘āliya 
ast tasnifāat o maktūbāt-i way ' $a j \bar{a} \cdot i b$ o gharāib-i bisyār dārad kih 'aql-i cāqilān az dark-i ān ‘ājiz ast dar sāl-i hazār o sĩ o čahār dar ākhir-i māh-i safar safar-i ākhirat ikhtiyār namūd wa farzandān-i 'ālim o -āmil o gābil gudhāsht). .96 It is evident that Muhammad Șādiq is not conscious of any special historical role performed by Sirhindi. On the basis of the material now available, we tend to conclude that Sirhind $\bar{I}$ was not considered in the seventeenth century as an important thinker except by his disciples and by the "ulamä. involved in the controversies surrounding him. 5. The eighteenth century.

The interest in Sirhind $\mathbf{I}$ seems to have diminished after the controversy of the late seventeenth century subsided. The section on Sirhindi in Subhat al-Marjān min Athār Hindūstān by $\bar{A} z \bar{a} d$ Bilgrāmī is devoted almost exclusively to the various possible interpretations of the controversial letter 11 of the first volume. There is only a brief reference to Sirhindi's imprisonment and his stay in the imperial camp. Bilgrāmi does not attach any special significance to these events. Neither does he consider Sirhindi a man engaged in a struggle against the heresies of Akbar. 97

Shāh Wali Allāh deals with the thought of A hmad SirhindI in several works. Faysala-yi Wahdat al- 
Wujūd wa al-Shuhūd, in which he demonstrated the essential identity between Ibn al-“Arabī and Sirhindī, has received considerable attention. $98^{\circ}$ The debate touched off by this book has also been already described.99 Another relevant work by Shāh Wali Allāh, the Shawāhid al-Tajdìd, ${ }^{100}$ is still in manuscript, and an account of it seems necessary.

The Shawähid al-Tajdīd begins with an analysis of the famous hadith about the centennial mujaddidūn. Shāh Wali Allāh maintains that this hadīth refers to a person endowed with all the perfections and capable of taking the place of the Prophet in his own age. 101 Sirhindi is, in his view, the mujaddid who was sent at the beginning of the eleventh century. He then enumerates eleven "witnesses of renewal" (shawāhid al-tajdīd) to prove that Sirhind $I$ indeed was the mujaddid. The "witnesses" are the followin:

1) he spread religious knowledge and șūfi "secrets" far and wide

2) he performed innumerable miracles

3) he was accepted as the mujaddid by the greatest 'ulama' of his age, such as 'Abd al-Hakim Siyālkōtĩ

4) he explained the Naqshbandi discipline in an unprecedented manner 
5) God chose for him thousands of excellent associates who assisted him in his work

6) God enabled him to understand the mysterious letters at the beginning of some bur'ānic suwar (almuqatta'āt al-furqāniyya) and the ambiguous verses of the Qur'ān (al-mutashābihāt al-qur'āniyya)

7) he was subject to the cruelty of the Sulțān but persisted in proclaiming the truth

8) God opened for him the doors of "inner knowledge" ( $i$ ilm-i bātin) in an unprecedented manner 9) a large number of infidels accepted Islām 102 and thousands of Muslims repented their sins - all due to his influence

$$
\text { 10) } 103
$$

11) God enabled him to give an account of wilāya, nubuwwa and risāla; of the perfections of the steadfast Prophets; of the stages of khilla and mahabba and of the special qualities of Muhammad. It is therefore clear that he was the mujaddid of the eleventh century. 104

It is noteworthy that Shāh Wali Allāh recognizes Sirhindi in this work as the Renewer of the eleventh century, not of the Second Millennium. This seems to be an implicit criticism of Sirhindi's theory of millennial renewal. However, in another epistle included in the 
same collection Wali Allāh recognizes Sirhindī as a sign (irhās) of a new period starting with the Millennium. 105 Whether this indicates a change in Wali Allāh's view of Sirhindi would have to be determined on the basis of further research in Wali Allāh's works. Shāh Walı Allāh's son, Shāh 'Ảbd al-'AzĨz Dihlawi maintains that the original contribution of Sirhindi to tasawwuf is the development of the concept of khilla. The şūfĩs before Sirhindi started their spiritual journey at the stage of loving (muhibbiyya) and were later able to reach the stage of being loved (mahbübiyya). Both relationships were one-sided. It was only with Sirhindi that the stage of khilla was reached. This is the stage when God and the süfi long for each other and the relationship is mutual. 106 This view of 'Abd al-'Aziz stems from Sirhindi's own description of the spiritual changes taking place with the advent of the Millennium, which we have described earlier. 107

Sirhindi's image in the eighteenth century was still that of a șufi teacher, engaged in the exploration of divine mysteries. It is, however, interesting to note that Shāh Wali Allāh includes among his eleven "witnesses of renewal" the fact that Sirhindi was cruelly treated by the Sulțān, yet persisted in 
proclaiming the truth. Shāh Walī Allāh sees in this behaviour a sign of Sirhindi's personal steadfastedness as a deeply religious man and does not attach any political or social significance to it. It appears, however, that the theme of Sirhindi's defiant attitude to the Sulţān, which originated in Naqshbandi hagiographies and has become a major component of Sirhindi's image in the modern period, was gaining strength in the eighteenth century. 6. Wakil Ahmad Sikandarpūrï.

The interest in Sirhindi does not seem to have been great in the nineteenth century. Towards its end, however, Sirhindi found a vigorous defender in the person of Wakil A himad Sikandarpūri who wrote three books in his defense. 108 Sikandarpūrī was a member of the Mujaddidi branch of the Naqshbandi order 109 and wrote his books out of the desire to exonerate Sirhind Irom the charges levelled against him in the seventeenth century, rather than because of any particular development in his own time. Sikandarpüri's books are similar in nature and scope to the pro-Sirhindi works written during the time of Awrangzēb. He reiterates Muhammad Bēg's claim that al-Barzanji wrote Qadh al-Zand on the basis of wilfully distorted translations of Sirhindi's letters. He also charges that al-BarzanjI accepted a bribe from SirhindI's 
enemies for writing the book. 110 Drawing his information from stiyyat al-Wahhāb, he speaks extensively of persons who responded favourably to Wiuhammad Bēg's activities in al-Hijāz and issued fatāwā in support of Sirhindi. ${ }^{111}$ He then compares Sirhindi with other great șūfis who were attacked by their contemporaries, 112 quotes traditions urging that no şüfi be harmed or declared an infidel, 113 and attempts to undermine al-Barzanji's argument that the concept of millennial renewal is meaningless and heretical because the second millennium will not be allowed to run its course. ${ }^{114}$

We have already referred to some of the material from Hadiyya Mujaddidiyya, ${ }^{115}$ which was written in order to refute Shaykh 'Abd al-Haqq's arguments against Sirhindi. It is also in this book that Sikandarpūri indicates the reasons for which he holds Sirhindi in such a high esteem. They are the following:

1) Sirhindī spread religious knowledge and șūfĩ "secrets"

2) he understood the mysterious letters at the beginning of some Qur'ānic suwar and the ambiguous verses of the Qur'ān.

3) he knew the names of the Indian Prophets and of their followers 116 
4) he was able to give an account of wilāya, nubuwwa, risāla, khilla, and mahabba and of the special qualities of the Prophet. 117

It will be recalled that three of these four points were mentioned by Wali Allāh in his Shawāhid al-Tajdĩd. Sikandarpūri's appreciation of Sirhindi does not differ from that of Sirhindi's supporters in the seventeenth and eighteenth centuries.

7. The modern period.

The mediaeval approach to Sirhindi, of which Wakĩ A hmad Sikandarpūri seems to be the last representative, is characterized by exclusive attention to Sirhindi's thought and șüfĩ experiences. Both SirhindI's supporters and his critics discuss his views in the abstract and try to determine whether they are compatible with what the critics consider to be the immutable principles of Islām. 'l'hey do not see, and are not interested in, any connection between his approach to ta awwuf and the context in which it crystallized. 'l'hey are not concerned with those letters in which Sirhindi expresses his opinions on the situation of Islām in India during the reigns of Akbar and Jahāngīr or those in which he demands that reforms be introduced into the administration of the Mughul empire.

A fundamental change in the approach to 
Sirhindi occurred with the publication in 1919 of the

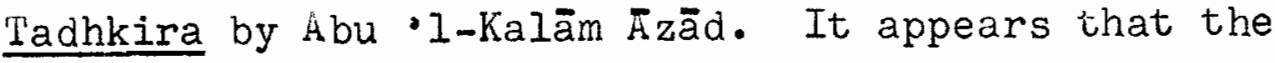
Tadhkira is the first work in which Sirhindi is described as the person who reacted single-handedly to the religious corruption that spread in India during the reign of Akbar. According to $\bar{z} \bar{a}$ d the country was at that time glutted with 'ulamāo and șüfis who were all bemoaning the prevalent sad situation without making any attempt to remedy it. T'he biggest disaster of India was that tasawwuf, corrupted by innovation and ignorance, was reigning supreme. Religious license (íbāhat) was euphemistically called the "esoteric way" (tariq-i bätin). The whole country was ignorant of the shar'I sciences. During the reign of ikbar innovations were spread by the government itself, with active assistance of the wicked 'ulamà' and the worldly (dunyā parast) șūfĩs. A hmad Sirhindi, says $\bar{z} z \bar{a} d$, was the only person who had the courage and stamina to embark single-handedly upon a campaign of reform and renewal (islāh o tajdid) and to stand up to the emperor himself. the rest of the 'ulama'. continued to teach in their religious schools and to write insignificant commentaries and super-comnentaries; in some cases they even issued fatāwā declaring Sirhindi an infidel. Sirhindi's mission was not limited in $\bar{A} z \bar{a} d$ 's view to the repudiation of religious innovations and the 
introduction of tawhidd-i shuhūdi. His activities had a much wider scope; he transcended tasawwuf and was fulfilling the tasks of the Prophets of old. 118

The image of Sirhind $I$ in the Tadhkira is radically different from that reflected in the earlier literature. SirhindI is seen here as a rebel against the government in power. He is a reformer in the field of religion as well as in other fields which remain unspecified by $\bar{A} z \bar{a} d$. He comes at a time when the lives of the Piuslims of India are dominated by tasawwuf and combats this situation. The new image of Sirhind $I$ faithfully reflects the new situation of the Viuslim community in India and the political attitudes of $\bar{\AA} \bar{a} d$, who wrote the Iadhkira while he was detained because of his anti-British activities. He considers taşawwuf as the cause of the torpor that had paralysed the Muslim community in the past and discards it in favour of direct political action against the government in power. 'The past and its personalities are viewed by him through the mirror of the present. The image of Sirhindi is no longer that of a man of religion interested solely in the exploration of the mysteries of God and His creation; he is a religiously minded rebel against the conditions surrounding him. The Tadhkira of Abu '1-Kalām Azād set the 
tone for the treatment of Sirhind $\mathrm{I}$ in subsequent works. Sirhirdi has since been considered as the leader of a religio-political movement which set out to nullify the consequences of Akbar's policies. He is seen as a religious thinker who rejected the idea that Islām and Hinduism can be reconciled by eliminating the unessential elements in both and who reaffirmed the distinctiveness and unique character of Islām. By his stand and activity he "checked the process of Indian Islam's disintegration into syncretic heresies". 119 Characteristic of the new approach is the Urdū work by Muhammad Miyān, The Glorious Past of the 'Ulamā' of India. It is noteworthy that a book bearing such a general title should start with a description of Sirhindi's life and achievements without paying any attention to those 'ulamā' who lived and worked in India previously. After a description of Akbar's heretical views and policies, Muhammad Miyān turns to Sirhindī's plan of reform. According to the author, Sirhindi set out to reform the ruling circles of the empire. The author maintains that Sirhindi's success was complete and "it appears that all the important sunn $\bar{I}$ ministers and officials of the courts of Akbar and Jahāngīr were important members of the movement of the Mujadid" (ma 'lūm hōtā hay kih dawlat-i akbarī o jahāng İrī kēè 


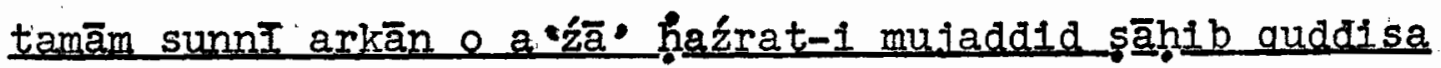

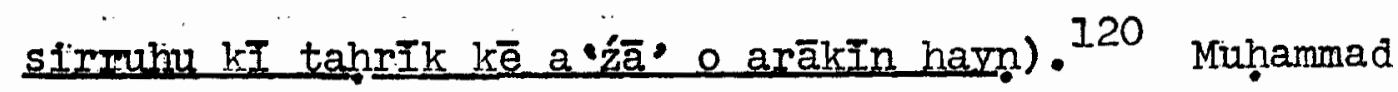
Miyān is concerned with Sirhindi's political activity to such an extent that he devotes a whole chapter of his book to the question why SirhindI, with all the power and influence that he had acquired, did not attempt an actual rebellion against the government whose policies he opposed (mujaddid sāhib nē baghāwat kvūn nahin kJ). H1s answer is that SirhindI's movement was not strong enough during the reign of Akbar and there was also the possibility that the emperor might eventually repent. Muhammad Miyān also maintains that, according to the Islamic tradition; Muslims should not rebel against a ruler unless his infidelity is beyond doubt. Such was not the case with Akbar. As for the time of JahāngIr, SirhindI had to consider the possibility that the Hindūs would seize the reins of government entirely as a result of internal strife among the Muslims and that the shi $I$ kingdom of persia would intervene on behalf of JahāngIr's shI 'I wife, Nūr Jahān. The only way of action open to SirhindI therefore was to influence the ruling circles by peaceful means. In an obvious reference to the methods used in Indla during the khila fat movement, Muhammad Miyān characterizes Sirhindi's approach to the Sulțān as "passive resistance" (mugāwamat bi-oI-sabr, 
-adam-i tashaddud ki jang) which was, in his view, also the method used by the Prophet Muhammad in Makka. 121 SirhindI's efforts were crowned with success. Jahāngīr Iistened to his preaching and made an important Islamic gesture by sacrificing a cow at the vanquished Hindu fortress of Kāngra. Sirhindi's activities created the atmosphere which eventually enabled Âwrangzēb to rule according to the principles of orthodox Islām.122 A similar approach is adopted by Fārūqi in The Kiujaddid's Conception of Tawhid. He affirms rather uncritically the historicity of Jahāngīr's complete conversion to SirhindI's view of Islām on the basis of the Naqshbandi hagiographies. ${ }^{123}$ In the main part of his book he has described the differences between wahdat al-wujūd and wahdat al-shuhūd clearly and succinctly. He tries, however, to present Sirhindi as a thinker who controverted Ibn al-'Arabi's un-Islamic wahdat al-wujūd and replaced it with wahdat al-shuhūd which is the true expression of Isläm.124 It is, of course, legitimate to maintain that Ibn al-'Arabi was a heretic; however, in a book concerned mainly with Sirhind $I$ one would expect the author to point out that Sirhind $\bar{I}$ himself did not see Ibn al-'Arabi in this light. Sirhindi did not consider his criticism of wahdat al- 
wujūd as a fight against heresy. Pārūqi completely disregards those passages in the Maktūbāt in which SirhindI explained and defended Ibn al-Arabi rather than refuted him. 125 The presentation of Sirhindi's attitude towards Ibn al-“Arabī is, therefore, distorted. FārūqI's concluding statement that "there can hardly be any doubt that the call of the Mujaddid to all irusalmans and Islamic mystics is

Away from Plotinus and his host

and

BACK TO MUHAMAD 126

as well as many other passages in the book, gives an unpleasant ideological flavour to an otherwise valuable presentation of an intricate problem in taşawwuf. Fārūqi's approach has had a considerable impact on subsequent research and was fully adopted by wurayshi. 127

More moderate is the appraisal of Muhammad Ikrām in Rūd-i Kawthar. Ikrām questions the prevalent interpretation according to which Sirhindi put an end to the heresy of Akbar. He rightly observes that this view was first expressed by $\mathbb{E} z \bar{a} d$ and that earlier sources do not see Sirhind $\bar{I}$ in this light. Ikrām maintains that Akbar's heresy had been eliminated before Sirhindi's letters were written and views Sirhindi's contribution to the development of Islām in India in a different 
manner. According to him, the importance of Sirhindi lies in the fact that he succeeded in propagating one süfi order over all India, thus giving to the country some measure of spiritual unity. By introducing the theory of wahdat al-shuhūd he resolved the differences between the "ulamā' and the șūfis. He also devoted great energy to combatting religious innovations and $\operatorname{sh} \bar{i} \cdot \bar{I}$ influences. Assuming the historicity of the Naqshbandi account of Sirhindī's meeting with Jahāngìr, Ikrām has warm words of appreciation for the courage displayed by Sirhindi when he pref'erred to be jailed rather than to prostrate before the Sulțān. People were heartened by this example, and the tide of unlawful practices was stemmed. 128

A completely new approach to Sirhindi has recently been adopted by two Indian Muslim writers, Habīb and Riźvi. In a short article on the Political Role of Shaikh Ahmad Sirhindi and Shah Waliullah, Habīb stresses SirhindI's fanatical hatred of the Hindūs and presents a considerable amount of evidence to prove that Sirhindi's political role is nothing but a pious legend, invented by his disciples and perpetuated by their credulous followers. 129 Habib maintains that "their (i.e., of Sirhindi and Wali Alläh) glorification is only a part of the modern separatist tradition which seeks solace and inspiration from those who were but shadows when 
compared to the real makers and motive-forces of our history."130 In order to prove his point, Habīb grossly exaggerates the importance of Sirhindi's anti-Hindu pronouncements which were, as we have seen, an unimportant part of Sirhindi's thought.

A much more detailed argument is presented by Riźvi in Muslim Revivalist Movements in Northern India in the Sixteenth and Seventeenth Centuries. The main thesis of this book is that the Indian Muslims have always rejected Muslim communalism and tried to evolve a culture capable of developing in the Hind $\bar{u}$ environment of India. While discussing SirhindĪ, Riźvĩ also stresses, with strong disapproval, his hatred of the Hindus 131 and maintains that neither he nor any of his disciples had any success in propagating their ideas. The cause of their failure was the deep attachment of the Muslims of India to the pantheistic philosophy of Ibn al-'Arabi and their rejection of the bigotry of Sirhindi and his followers. The world-view of Ibn al-'Arabi is seen by Riźvi as the ideology of communal harmony, while Sirhind $i$ is depicted as a narrow-minded representative of a tiny Muslim minority, unsuccessfully trying to disrupt the peaceful co-existence of Hindūs and Muslims. ${ }^{132}$ Riźvi's description of the response to Sirhindi's teaching is questionable in several respects. 
Firstly, his evidence for the failure of Sirhindi to influence the population of the various provinces is tenuous. 'ihere is sufficient evidence to support the view that Sirhindi failed to evoke favourable response from the "ulamā'; as for the reaction of the common people among whom Sirhind''s disciples were working, their response is largely unknown. But the fact remains that a large number of people corresponded with Sirhindi and sought to learn the science of tasawwuf from him. Sirhindi's occasional complaints about the performance of his disciples, which are given disproportionate attention in Riźvi's work, ${ }^{133}$ cannot nullify the overwhelming evidence that Sirhindī, indeed, was a șūf $\bar{I}$ teacher who gained considerable acceptance. Secondly, Riżvĩ assumes that Sirhindi's disciples were fomenting anti-Hindū sentiments whereever they went. This assumption is entirely baseless. We have seen that the question of the Hindūs is a peripheral one in Sirhindi's thought and that he deals with it almost exclusively in letters to Fiughul officials. When Sirhindi's disciples went to the various cities of India to propagate their order, they were teaching the Naqshbandi spiritual discipline rather than fomenting communal discord. To assume that Sirhindi and his followers encountered some organized popular opposition and to identify it with 
anti-communalism is gratuitous.

Thus, the peripheral elements in Sirhindi's thought have become the core of his modern image. Indian and Pakistani historians, living in a society in which an ever increasing number of people is concerned with political matters and in which the question of religion and state plays such an important role, turn almost instinctively to those parts of Sirhindi's teaching that can be interpreted as relevant to their modern problems. In contrast, Sirhindi's tasawwuf, which is the core of his thought but which is irrelevant and even undesirable in the eyes of many modern Muslims, has been largely ignored. Moreover, Sirhindi's views on the question of religion and state have become the criterion according to which his contribution to the development of Islām in India is being assessed. Those who maintain that Is aam should play a prominent role in the conduct of state have seen in Sirhindi their precursor. On the other hand, those affected by the modern theory of secularism consider Sirhindi's approach an unwarranted interference of religion in matters of state. Both groups have unfortunately based their judgment on a peripheral element in Sirhindi's thought. For Sirhindī was primarily a șūfī and must be assessed as such. 


\section{CHAPTER X}

\section{CONCLUSION}

The thought of Shaykh Aḥmad Sirhindi, as expressed in the works written after he joined the Naqshbandĩ order, is characteristically șūfĩ. The

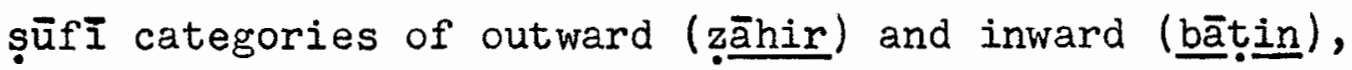
form (șüra) and essence (hagiga) are thoroughly applied to the various topics under consideration. It is because of the systematic application of these categories that the major Islamic concepts are discussed in Sirhindi's works on two different levels. Indeed, Islām itself can be, in Sirhindi's view, of two kinds. The common people, uninitiated into the mysteries of tasawwuf, are content with "formal" Islām. In contrast, the şûfi élite is able to reach the high stage of "essential" Islām. Likewise, Sirhindi speaks of the "formal" and "essential" aspects of Paradise, of infidelity and of the shari'a. Even the differences among the various schools of law (madhāhib) are regarded by him as differences between form and essence, and this is perhaps the most striking example of the total immersion of the concept of shari'a into the șufi worldview. ${ }^{1}$ Since the dichotomy of form and essence is 
common to both tasawwuf and tashayyú:, Sirhindi occasionally expresses ideas with a distinct shI' $\bar{I}$ colouring, despite his vociferous denunciation of the ShI'a in the more exoteric works. I'he most striking of these ideas is the distinction between the public "call" of the Prophets (da'wa) and their esoteric mission (mu*āmalāt-i bātiniyya) and the preference given by Sirhindi to the latter. ${ }^{2}$ The fact that Sirhindi assigned to 'AlI and the twelve a'imma a special spiritual task in the realm of taşawwuf also indicates that even Sirhindi, an assiduous sunnī șūfī, is not completely free from shi' $I$ elements in his thought. ${ }^{3}$

In view of all this, the prevalent assessment of Sirhindi as a person whose main objective was the restoration of the shari'a in India must be considerably modified. This assessment is oversimplified and does not take into account the peculiar șüfi attitude to the shari'a adopted by Sirhindi. It is, of course, true that Sirhindi always stresses the indispensability of the shari'a, but he also applies to it the șūfi dichotomy of form and essence and maintains that it is the inner, essential aspect of the shari'a that a Wuslim should strive to attain. That Sirhindi does not consider the formal, outward aspect of the shari'a as a Muslim's ultimate goal is clear also from the fact that, barring 
insignificant exceptions, Sirhindi never discusses problems of figh. Had Sirhindi's primary objective been the restoration of orthodoxy in Indian Muslim society, one would expect at least some interest in concrete legal questions on his part. Sirhindi displays no such interest and clearly is not a faqih. His lack of concern for legal details is in glaring contrast to the detailed descriptions of his spiritual experiences and analyses of șüfĩ concepts. SirhindI was first and foremost a şufi and must be seen primarily in this light. One cannot assess him properly by considering only the few letters to Mughul officials in which he demanded the strict implementation of the shari'a by the state. The overwhelming majority of Sirhindi's letters and other works deals with questions of tasawwuf. His main endeavour in them is to integrate his șüfi ideas into a sunnī frame of reference, without depriving them of their peculiar șüfi flavour. Ihis endeavour manifests itself in the clearest fashion in Sirhindi's descriptions of the supreme spiritual achievements of a șūfĩ. Sirhindi calls these achievements the "perfections of Prophecy" and maintains that they can be arrived at only by assiduously following the Prophet and his companions. As we have seen earlier, the meaning of Prophecy in this context is fundamentally different from 
its meaning in the works of the mutakallimūn. Sirhindi chose to use the concept of Prophecy for the description of the highest șūfi achievements because of the high standing of this concept in the sunni world-view. 4

Further research must be done before the place of Sirhindi in the development of tasawwuf can be properly assessed. Not much is known as yet about the eighteenth century Naqshbandiyya, and works such as the Bashārat-i Nazhariyya by Mirzā Mazhar Jān-i Jānān are still in manuscript. Yet it is in works of this kind that we are likely to find the clue for the proper assessment of Sirhindi's significance in the history of tasawwuf. Sirhind''s present significance for Indian and Pakistani Muslims is a result of his image as the restorer of orthodoxy and reviver of "pure" Islām. This image, which developed in modern historical writing since the Tadhkira of Abu 'l-Kalām $\overline{A z a ̄ d}$, reflects twentieth century developments in the Indian subcontinent rather than the seventeenth century thought of A ḥmad Sirhindi himself, who was primarily a șüf and not a thinker interested in the relationship between religion and state and between Viuslims and Hindūs. The latter questions constitute only a peripheral element in his thought. 
Appendix A

Bankipore MS., vol. 17, mo. 1586, fils. $1888^{10}-1890^{19}$

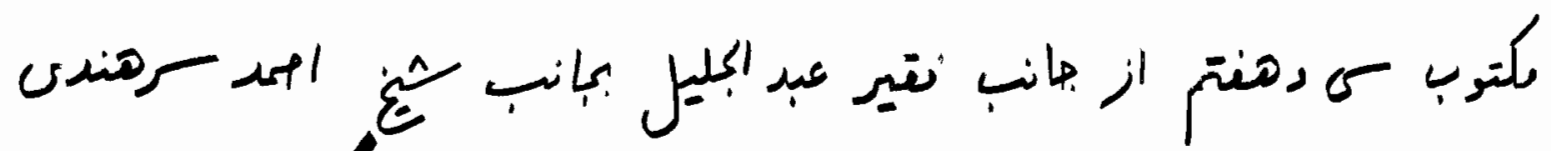

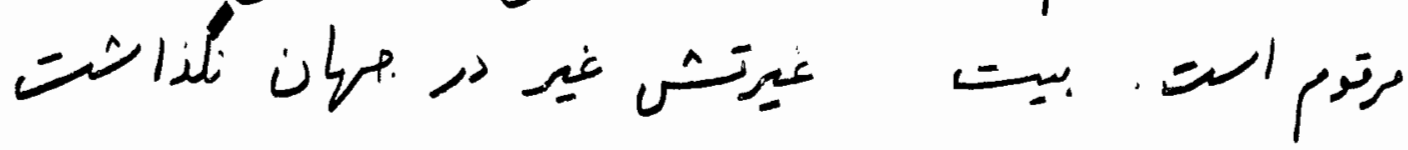

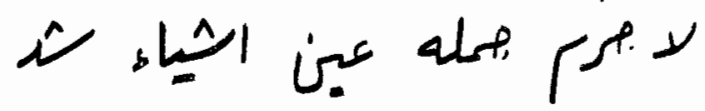

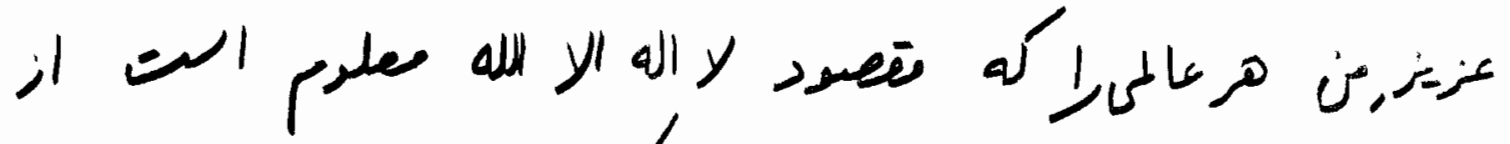

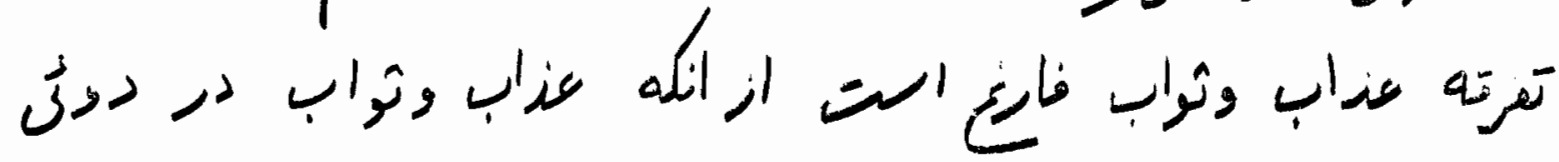

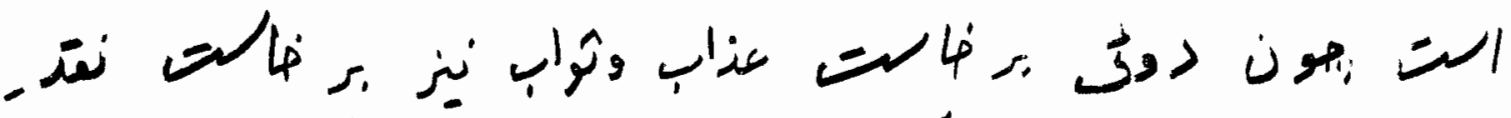

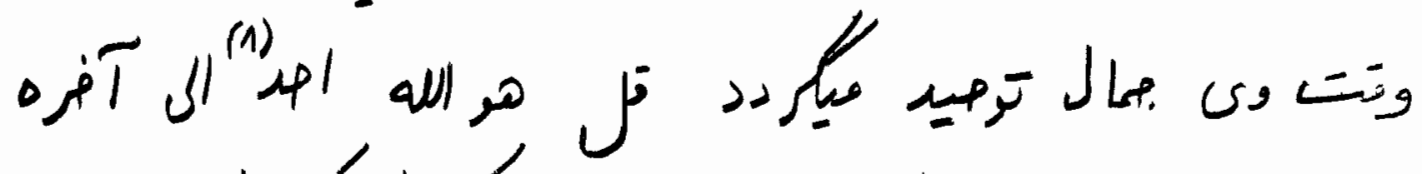

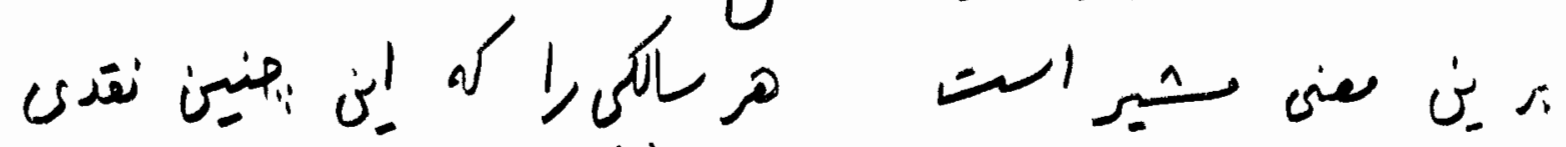

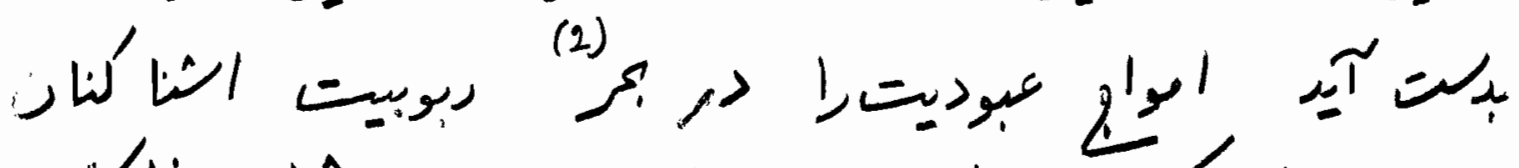

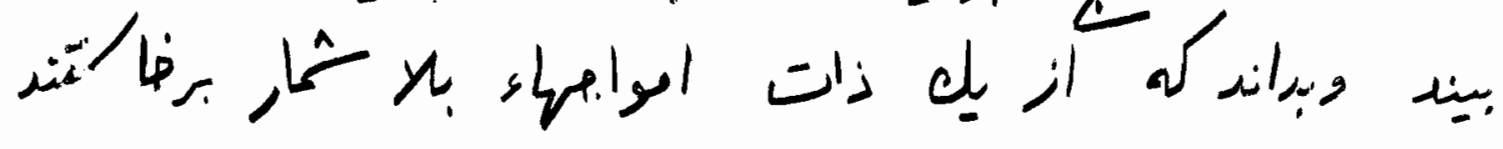

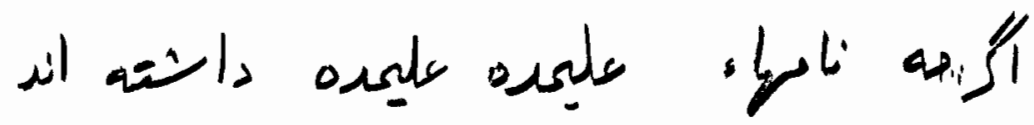

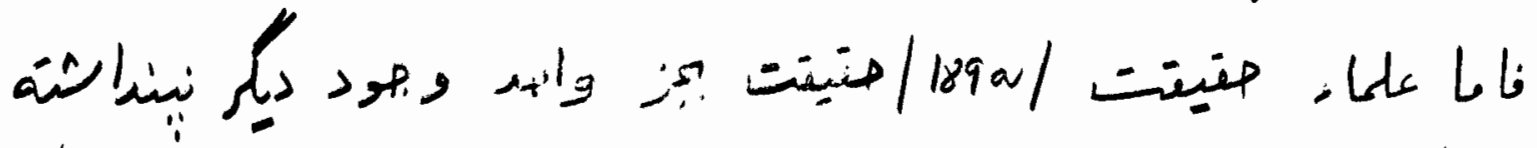

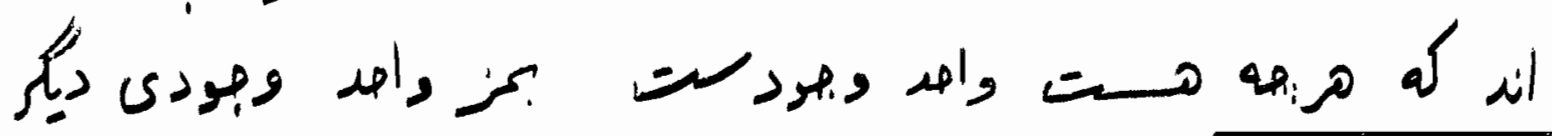
text: ت $\quad$ (2) Qurän 112,1 (1) 


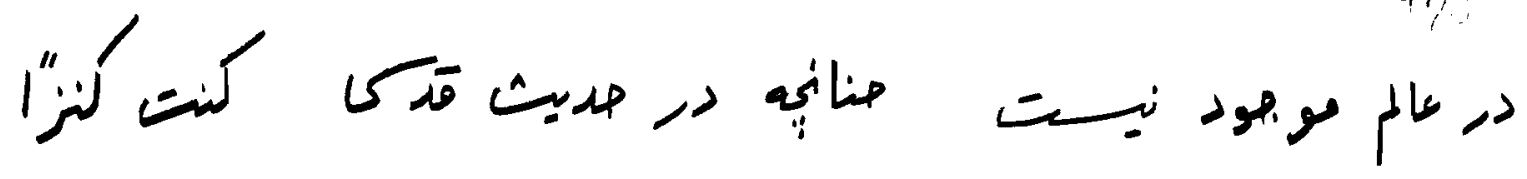

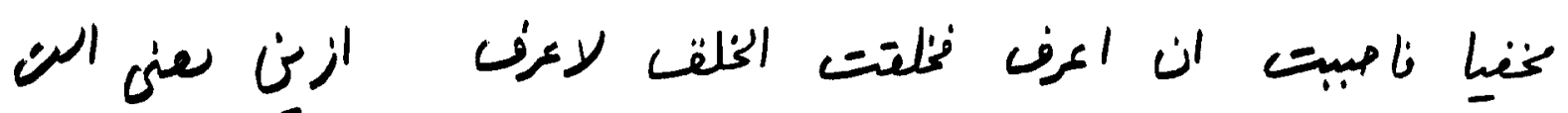

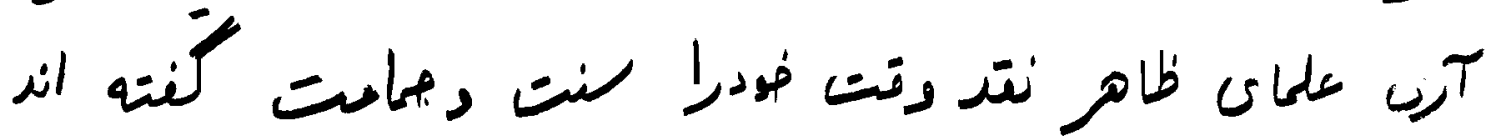

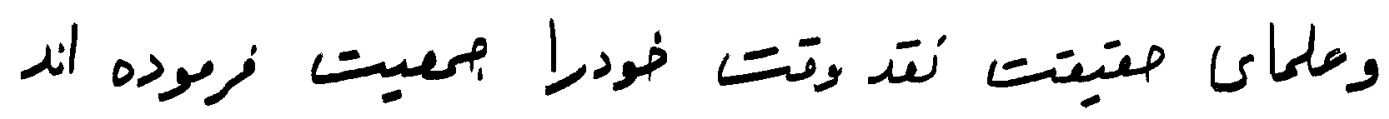

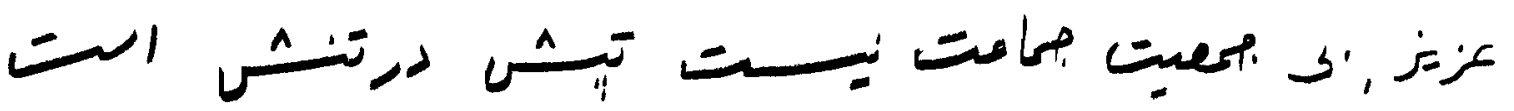

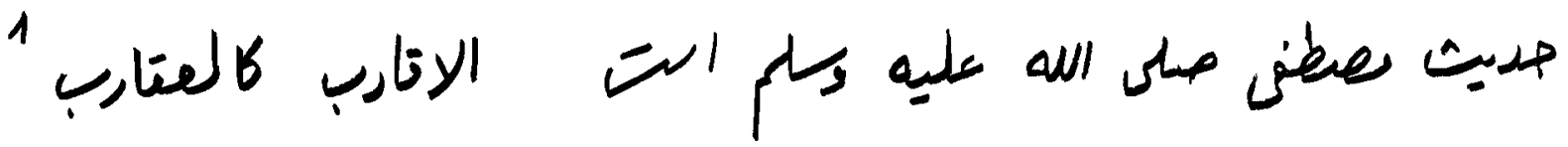

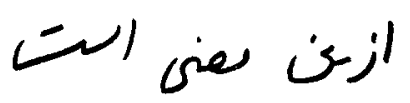

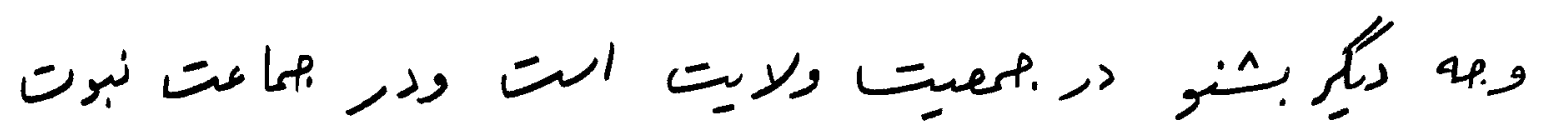

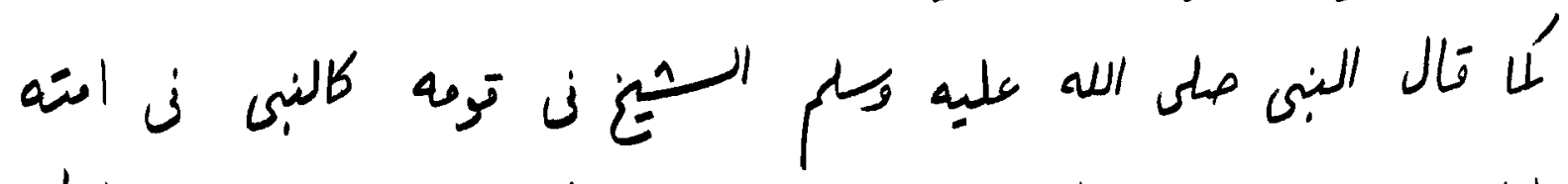

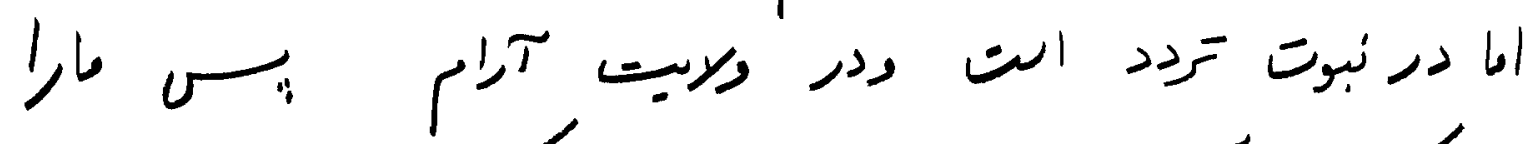

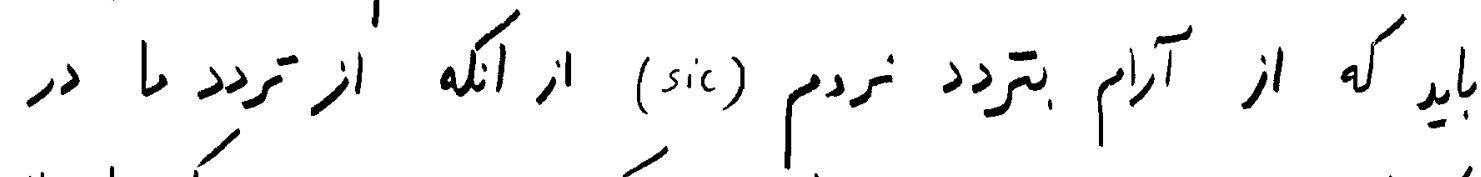

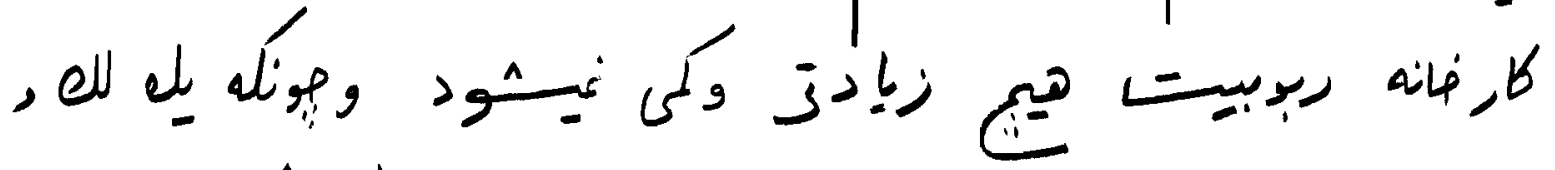

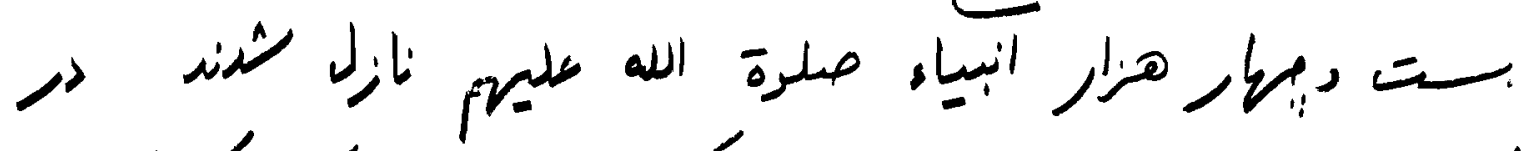

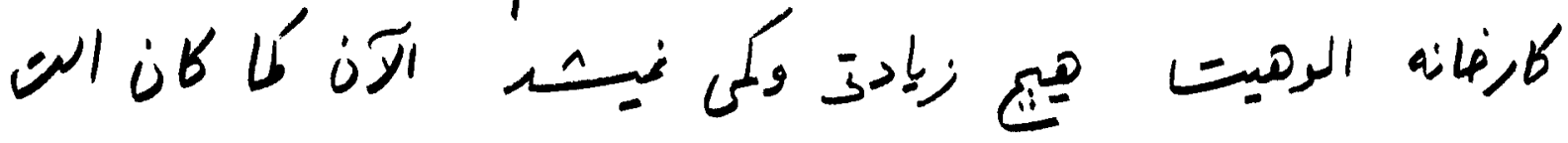

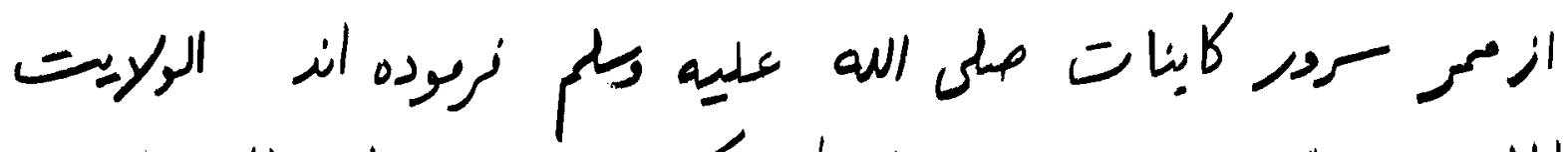

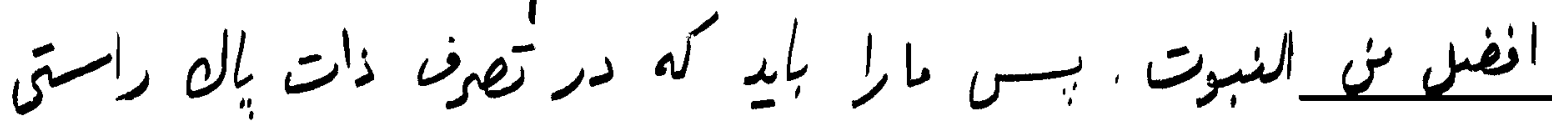
text: كار

(1) 


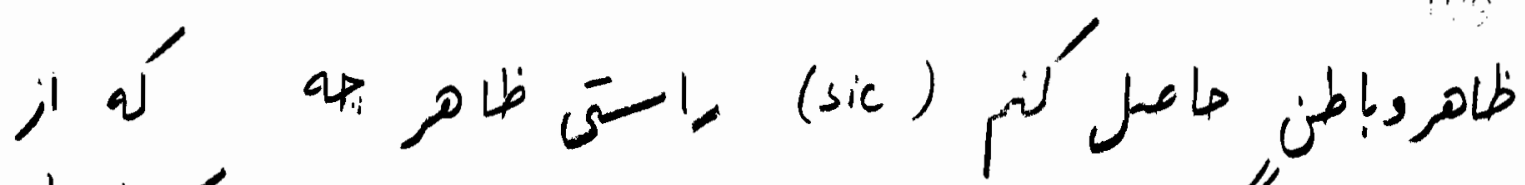

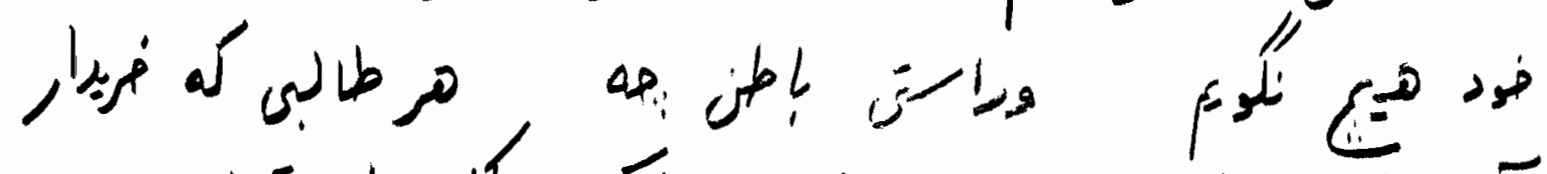

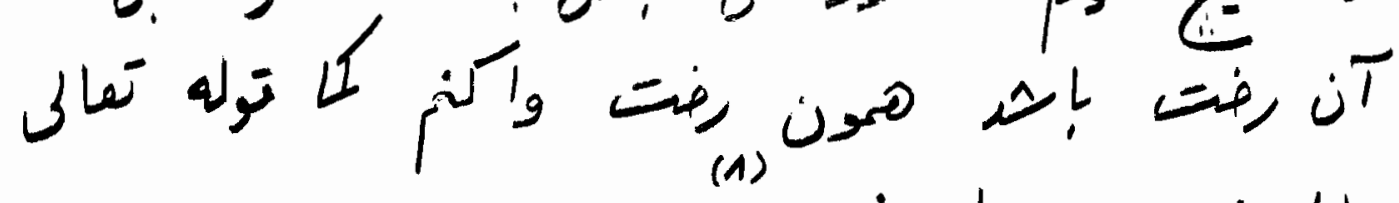

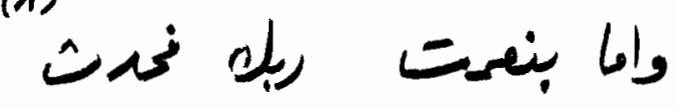

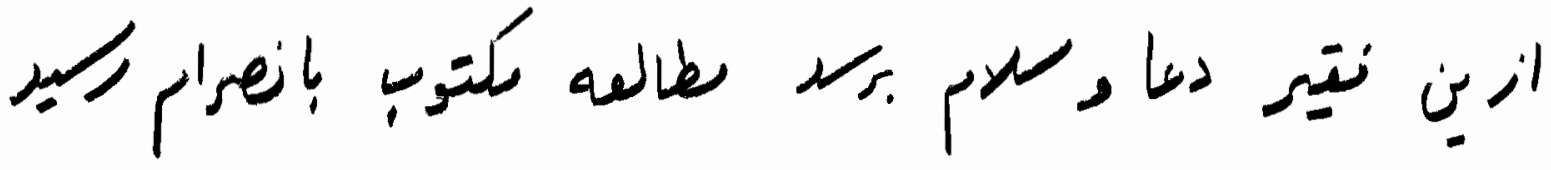

Quviàm 93, 11 (1) 
Appendix B.

Qușunz, Máāarij al-Wilāya, p. $708^{6-16}$

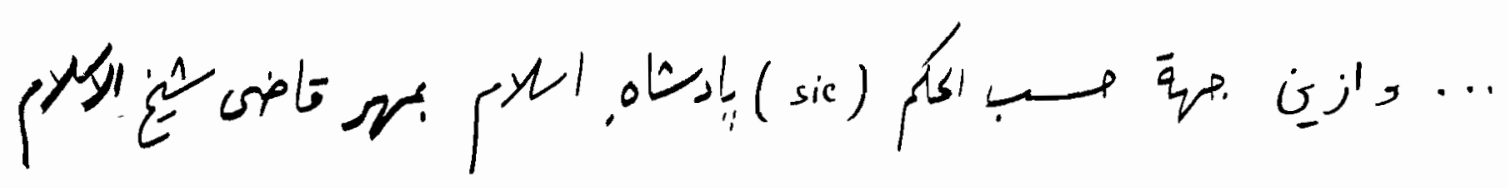

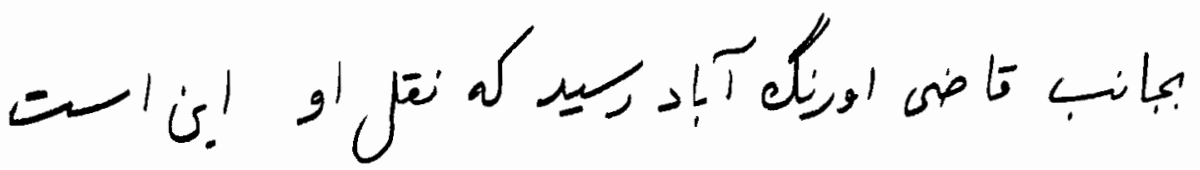

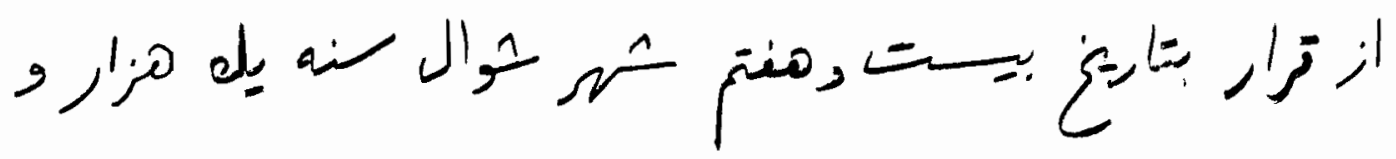

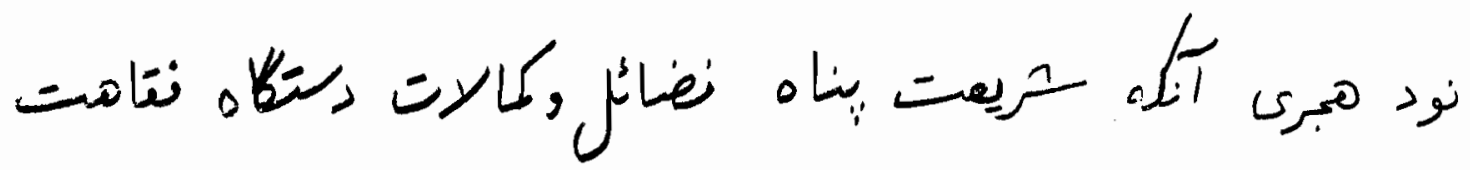

انتباه قاضى هرايست الله بعانيت بإثند

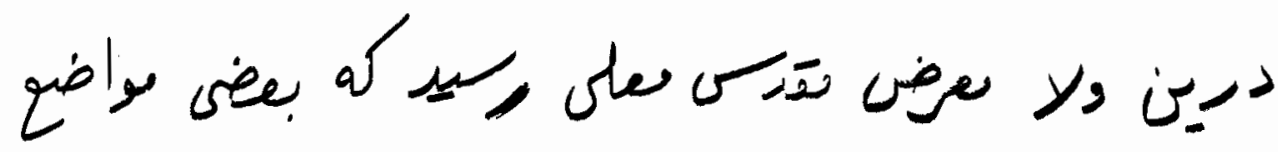

مكتوبات شئ اهد سرهندى طاهر ل در كالنة عتايد اهل

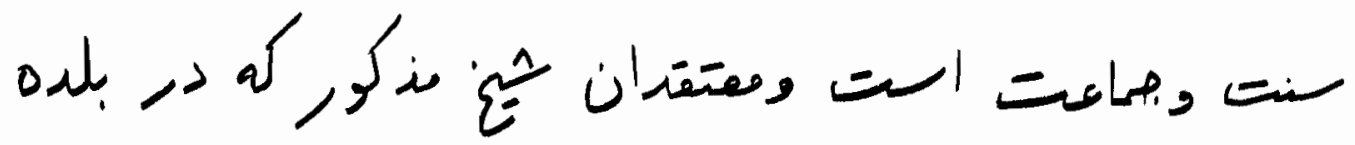

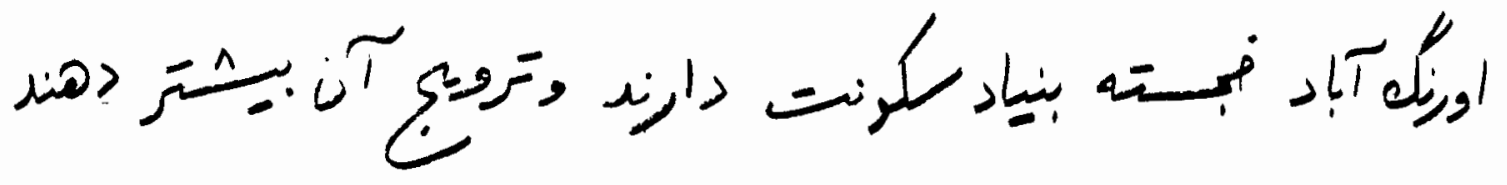

وتدريستى مينمانيد اعتقاد 


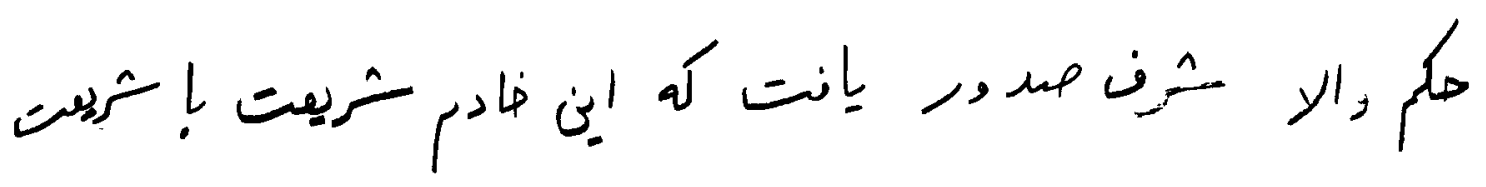

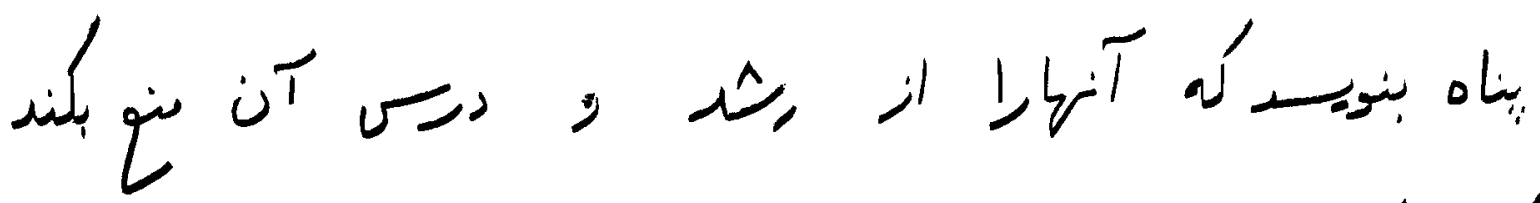

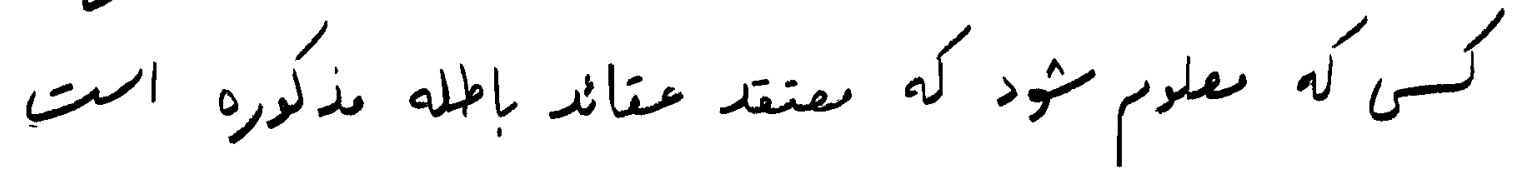

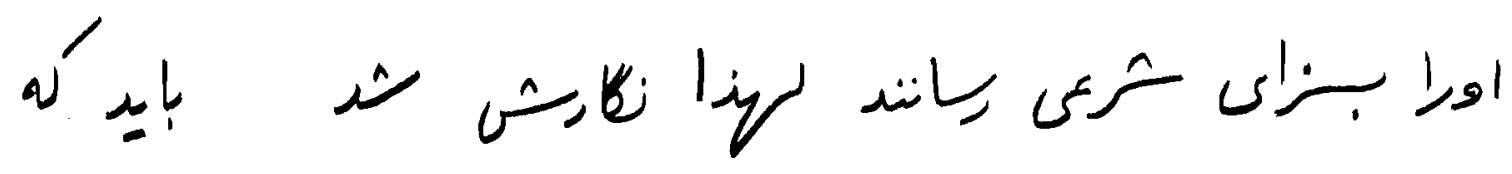

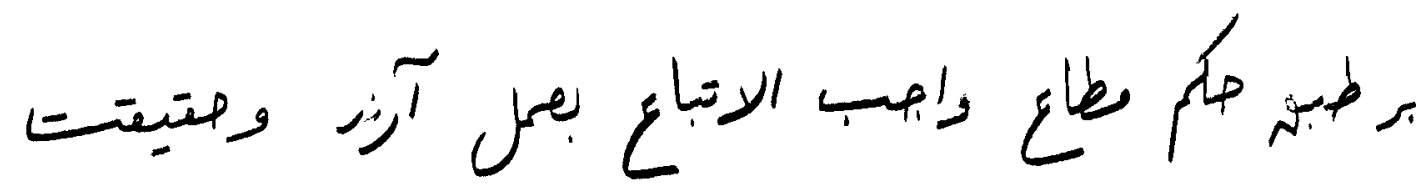

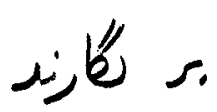

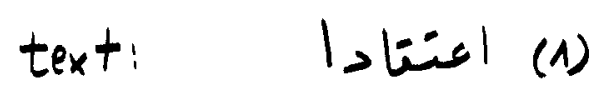


Appendix C

al-Barzanj', Qadh al-Zand, fol. $4 b^{11-26}$

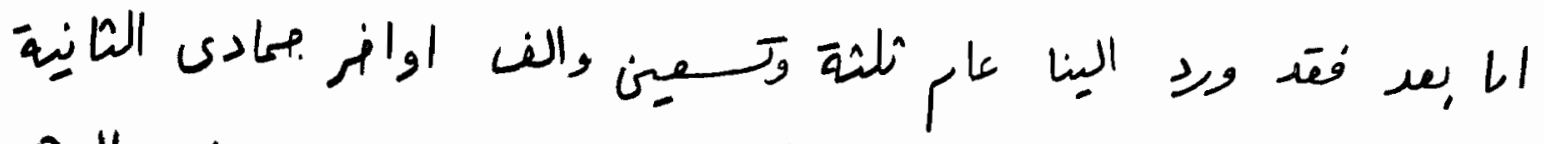

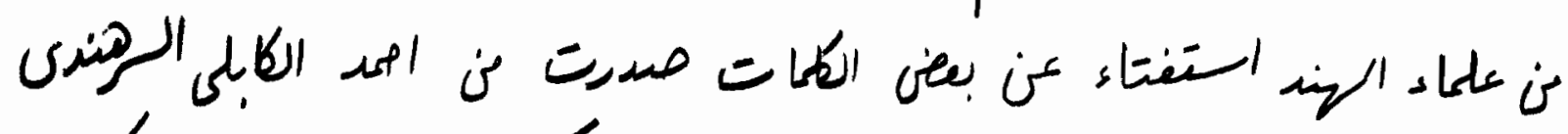

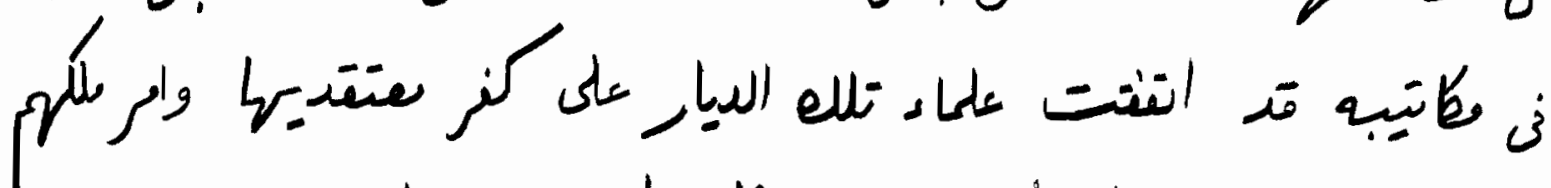

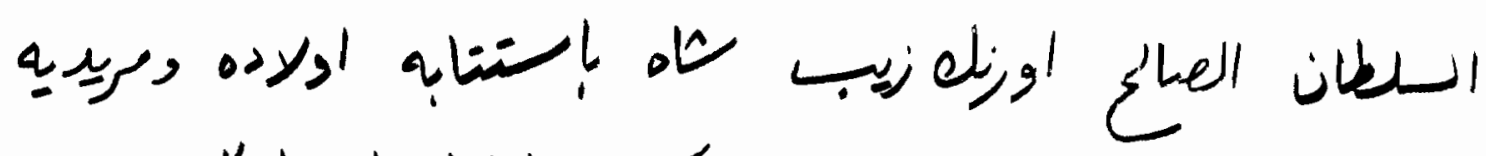

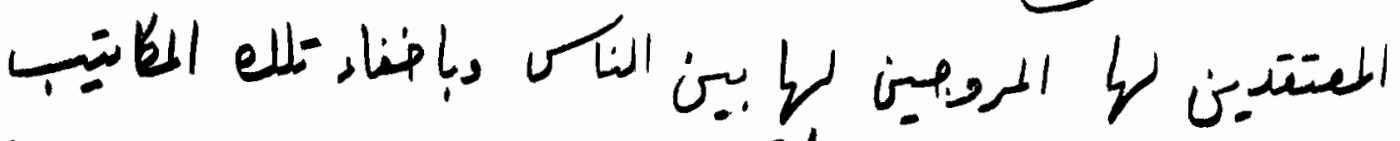

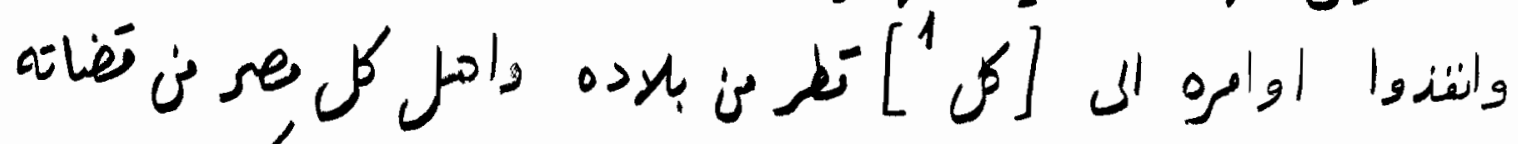

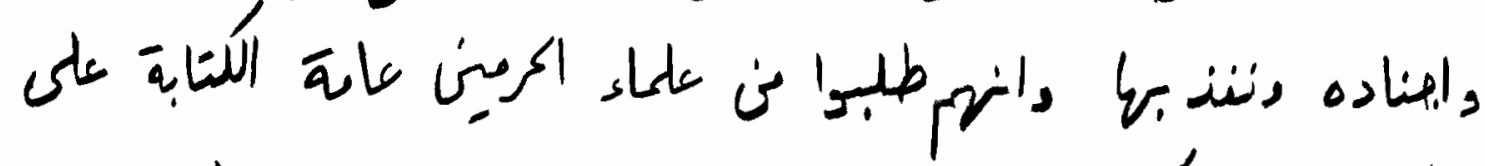

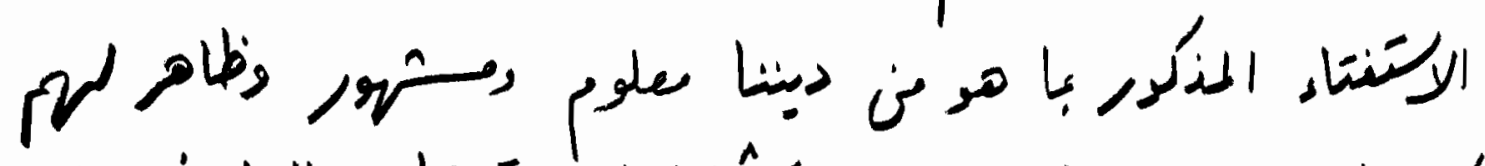

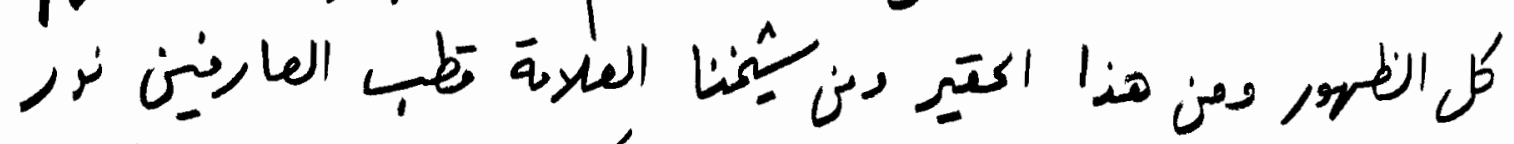

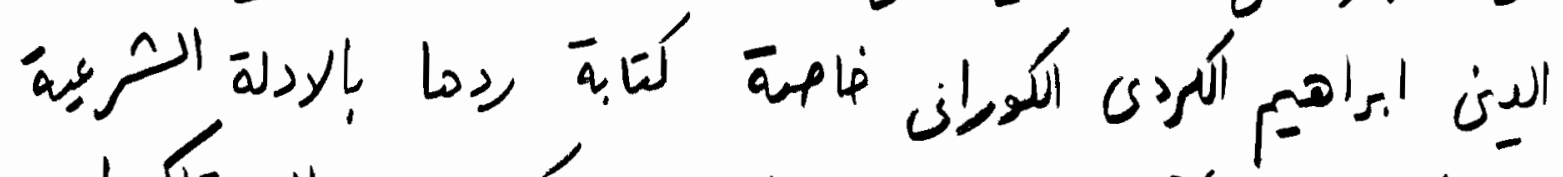

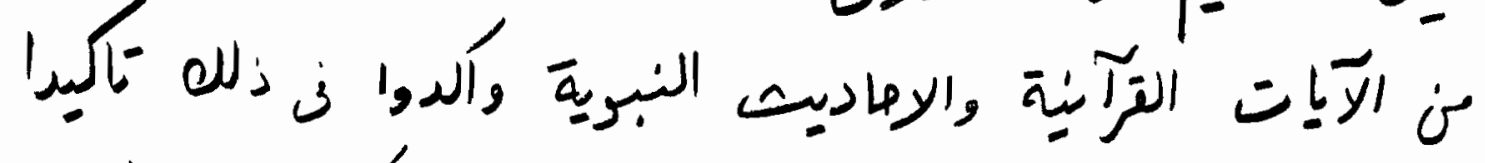

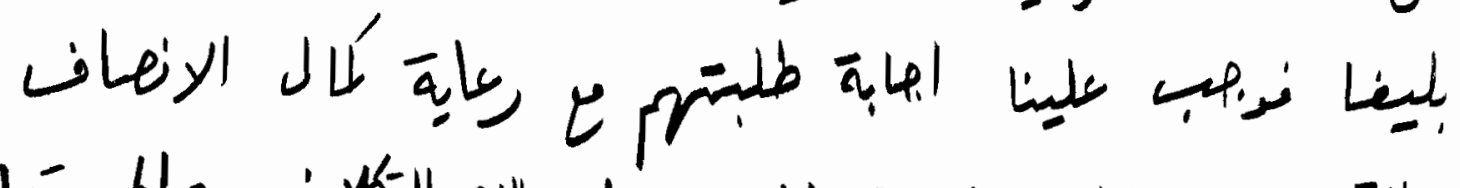

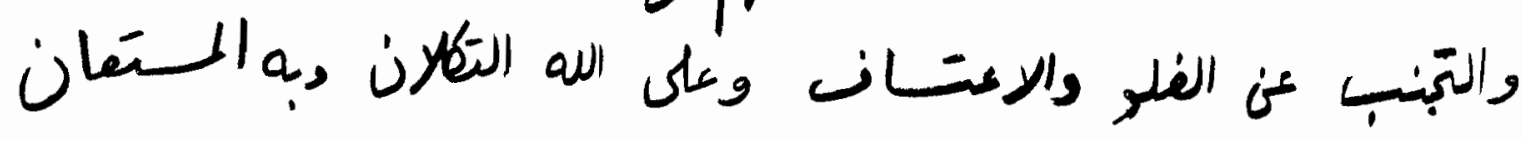

omitted in the text (1) 
al-Banzanji, al-Näshive al-Najjiven, fol, $3 b^{3-1}$

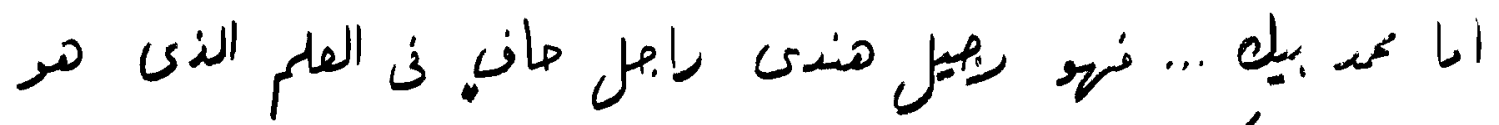

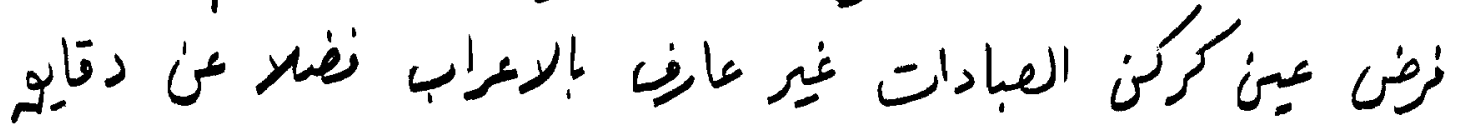

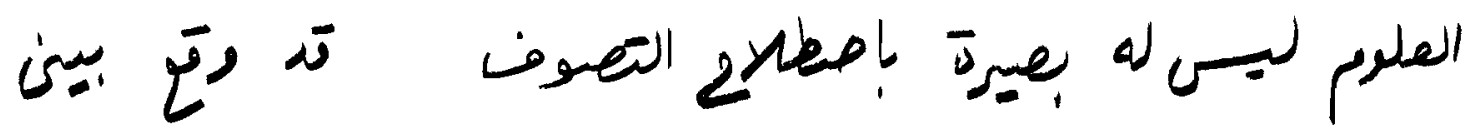

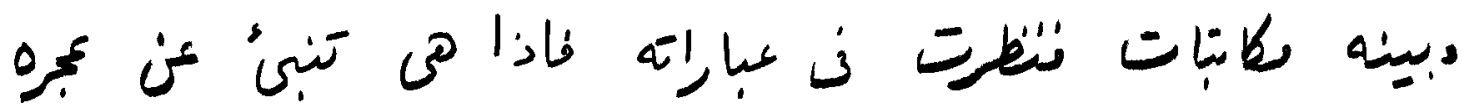

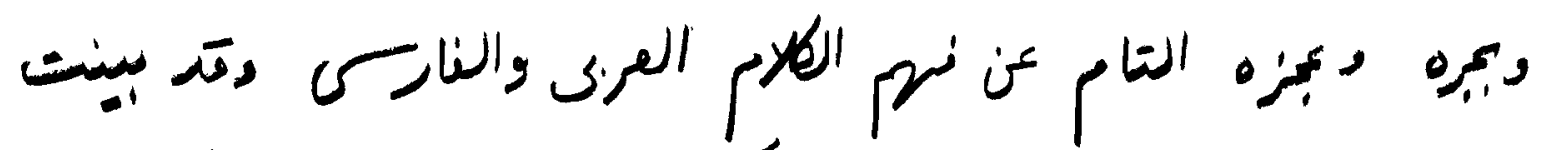

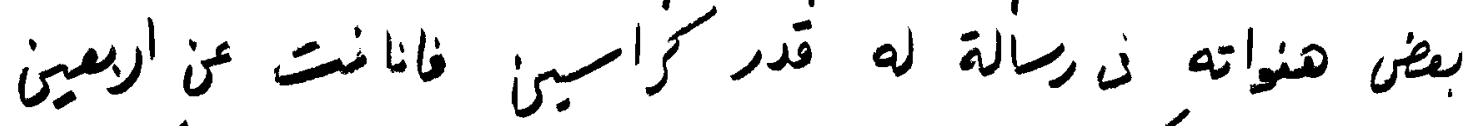

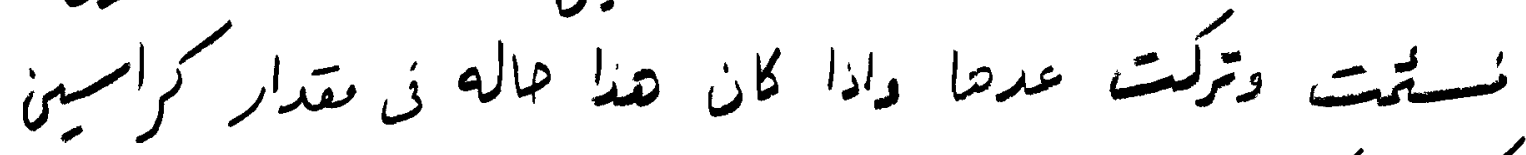

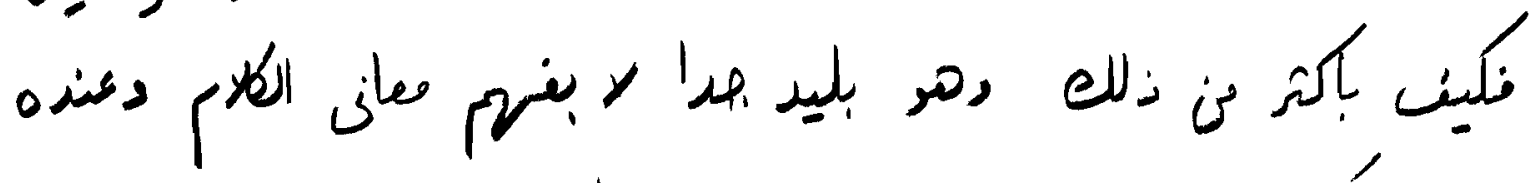

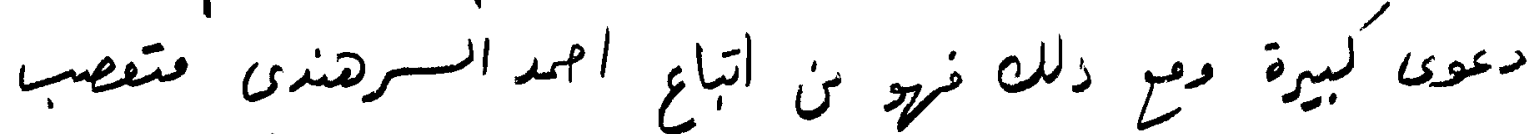

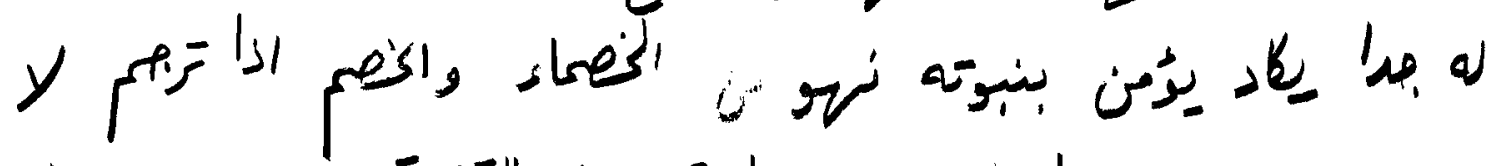

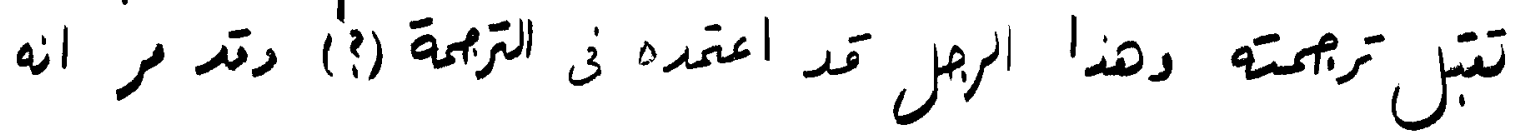

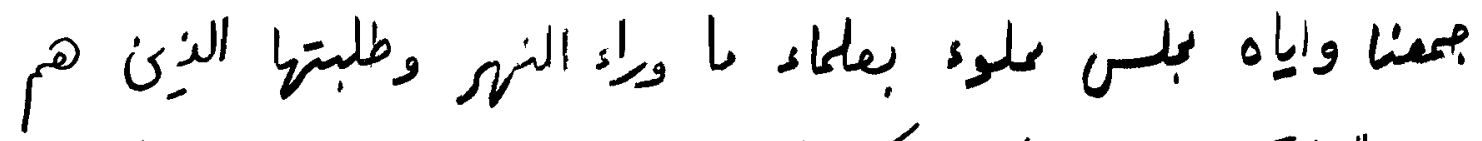

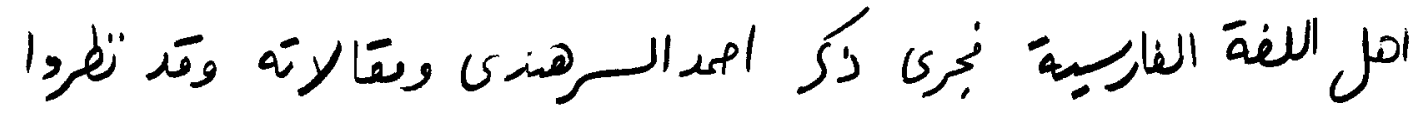

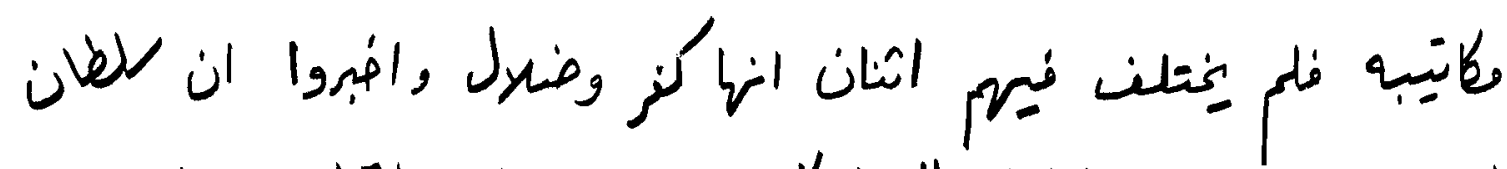

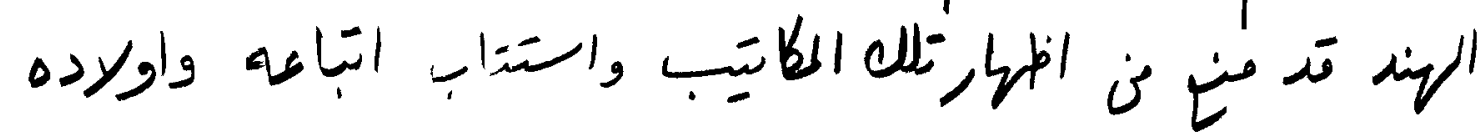

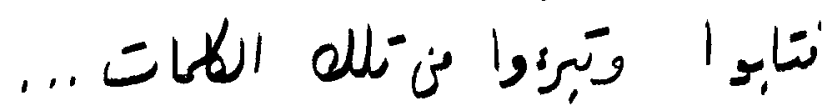




\section{NOTES TO CHAPIER I}

$I_{\text {Not all the sources used have been described }}$ in this chapter, nor do all of them fit the suggested classification. Our intention here is to describe the principal sources, to assess their contribution to the work as a whole and to draw attention to the problems arising from their use. A full list of sources will be found in the bibliography.

$2_{\text {All }}$ our references are to the Lucknow 1889 edition, unless stated otherwise.

${ }^{3}$ By Mustaqīm Zāda Sulaymān Sa’d al-Dīn. Istanbul 1277.

4Tuhammad Niurād al-Manzāwĩ, Mu'arrab al= Maktūbāt al-Sharīfa al-marsūm bi-’l-Durar al-Maknūnāt al-Nafísa. Makka 1316.

5 By Qāḍi ‘Alīm al-Dĩn, Lahore 1913. See EI², s.v. Ahmad Sirhindi. This work has not been available to us.

6 The three chronograms are durr al-ma'rifa, nūr al-khalà'iq and ma'rifat al-haqā'iq. See, Maktūbāt, vol. $3, \mathrm{p} \cdot 3^{21} ; \mathrm{p} \cdot 4^{7}$; Zubdat al-Maqāmät, p. $240^{20-21}$; Haźarāt a1-Quds, fols. $54 \mathrm{~b}^{6}-55 \mathrm{a}^{7}$.

7 The last letter of volume 3 bears the number 123, but letter 39 is missing from the editions available to us. 
It was intended that each volume contain letters in number having some significance in the Islamic tradition. The 313 letters of the first volume correspond with the number of the prophets and of the shuhada. $\bar{a}^{\circ}$ who fell in the battle of Badr; the 99 letters of the second volume correspond with the 99 Beautiful Names (al-asmā' al-husnā). The third volume was intended to contain 114 letters to correspond with the number of the chapters of the Qur'ān; however, Sirhindi died soon after the completion of the 114 letters of the third volume and the material that was to become the beginning of a prospective fourth volume was included in the third one. See Maktūbāt, vol. 2, p. $2^{15-23}$; Zubdat al-Maqāmāt, pp. $240^{19-} 241^{10}$; Haźarāt al-Quds, fol. $44 \mathrm{~b}^{2-5}$. These additional letters are not mentioned in the preface to the third volume, which mentions 114 letters only. See ibid., vol. $3, \mathrm{pp} \cdot 3^{21}-5^{1}$, especially p. $4^{15-23}$. $8_{\text {ibid. }}$, vol. $2, \mathrm{p} \cdot 2^{15-18} ; \operatorname{vol} \cdot 3, \mathrm{p} \cdot 16^{24}$.

9Thus the earliest letters, addressed to Sirhindi's preceptor al-Bāqi bi-'llāh, are found at the beginning of the first volume. We read about Sirhindi's plans to undertake a trip to Delhi and Fgra in an earlier letter (ibid., vol. 1, p. $78^{9-10}$ ) and about his return in a later one (ibid., vol. I, p. 9920-21). Sirhindi defends himself against accusations levelled against him 
in connection with letter 87 of the third volume in letter 121 of the same. The controversial letter 11 of the first volume is mentioned by its number in letter 192 of the same volume (ibid., vol. 1, p. 191 10-12); this means that the letters were arranged in their present order and known by their numbers even before the volume was completed. Niany of them are also mentioned by their present numbers in the polemical literature of the 17 th century (e.g., dadh al-Zand, fols. $15 \mathrm{a}^{17-18}$; $18 a^{8-9} ; 19 a^{21-22}$ and elsewhere).

10 Volume 1: Yār Muhammad al-Jadīd al-Badakhshĩ al-Ṭālaqānī (Maktūbāt, vol. 1, p. $2^{13-15}$ ). Volume 2: 'Abd al-Hayy Čākar Hișārī (ibid., vol. $\left.2, \mathrm{p} \cdot 2^{18-23}\right)$

Volume 3: Muhammad Nu'mān b. Shams al-Dīn Yahyā (ibid., vol. 3, p. $4^{7-12}$ ).

${ }^{1 I_{A}}$ letter by $A b d$ al-Jalil SiddIqI to Sirhindi is preserved in Bankipore MS. XVII, no. 1586, fols. $188 \mathrm{~b}^{10}-189 \mathrm{a}^{19}$. See infra, pp. 136-138. For another letter addressed to Sirhindi, see note 35 to the present chapter. We also have three "petitions" (arź dāsht) sent to Sirhindĩ by his son Muhammad Șādiq, describing the progress of his disciples and his own șüfi experience. These are published at the end of the first volume of the Naktūbāt (pp. $458^{11}-460^{13}$ ). 
12 Maktūbāt, vol. 2, p. $188^{14-16}$.

13 ibid., vol. 1, p. $306^{9-11}$; p. $333^{14-16}$; p. $452^{5-6,22}$; vol. $2, \mathrm{p} \cdot 7^{11-12}$; p. $151^{1-2,16-18}$; vol. $3, \mathrm{p} \cdot 196^{15-16}$. It is therefore difficult to agree with 'Irfān Habīb's suggestion that the letters were not known before they were "ready for public circulation" upon the completion of the first volume. See The Political Role of Shaikh Ahmad Sirhindi and Shah Waliullah in Enquiry 5 (New Delhi 1961), pp. 43-44.

14 Maktūbāt, vol. 3, p. $5^{20-23}$ ).

15 See infra, pp. 71-72 and chapter 5, note 41. $16 \mathrm{~A}$ modern Turkish translation is now available in Esseyyid Zeynelabidin Işik, Aleyīye Nasihat. "Redd-i Revāfiz tercümesi". Istanbul 1964. I have not been able to trace the Arabic translation by Shāh Wali Allāh, mentioned by Inayatullah (EI ${ }^{2}$, s.V. Ahmad SirhindI). Brief excerpts from it are given in $\mathrm{Nu}$ 'mānī, ed., Tadhkira-yi Imām-i RabbānĪ, Lucknow 1960, pp. 299-306. 17 Zubdat al-Maqāmāt, p. $131^{3-11} ; 132^{11-18}$. See also al-Kalām al-Munjī, p. $3^{6-7}$ from bottom, according to which Sirhindi composed this work at the age of 17.

Shaykh Inayatullah is mistaken when he says that the epistle in refutation of the shi $\bar{I}$ views is entitled tahliliyya ( $E I^{2}$, s.v. Ahmad Sirhindī). Risāla Tahliliyya is mentioned in several sources as a work 
different from the anti-shI' $I$ tract. It does not seem to be extant. See Tadhkira-yi Ulamā'-i Hind, p. 12 6-8 ; Subbat al-Marjān, p. $52^{6-8}$; Hadiyya Mujaddidiyya, p. $98^{3-10}$; al-Kalām al-Muniī, p. $6^{6-9}$.

$18_{\mathrm{Cf}}$. Ithbāt al-Nubuwwa, ed. Haydarābād (Sindh) 1383 , pp. $18^{10}-20^{14}$ and al-Ghazālí, al-Munqidh min alDalāl, ed. Cairo 1952, pp. 40 $14-42^{21}$; Ithbāt al-Nubuwwa, pp. $32-36^{4}$ and al-Munqidh, pp. $51^{5}-54^{19}$; Ithbāt alNubuwwa, pp. $36^{5}-37^{3}$ and al-Munqidh, p. 43 4-21. 19Ithbāt al-Nubuwwa, p. 6 $14-19$. The debate itself continues till page 9. The same debate is probably referred to in Zubdat al-Maqāmāt, pp. $131^{14}$ $132^{5}$, where Abu '1-Faźl is mentioned explicitly.

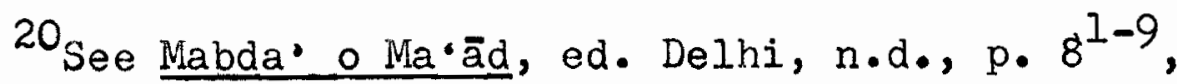
where Sirhind mentions his initiation into the Naqshbandi order.

$$
21_{\text {ibid., p. }} 68^{14-16} \text {. }
$$

22 Naktūbāt, vol. 1, pp. $277^{7} ; 303^{21-22}$.

23 Zubdat al-Maqāmāt, pp. $170^{10}-174^{18} ;$ pp. $141^{20}$ $144^{14}$; Haźarāt al-Quds, fol. $27 \mathrm{~b}^{1-3}$ and elsewhere. $24_{\mathrm{Mabda}}$ 。 Ma $\cdot \overline{\mathrm{ad}}, \mathrm{p} \cdot 60^{12-15} ; \mathrm{p} \cdot 64^{17} ; \mathrm{p} \cdot 67^{11-12}$. 25 We have used the manuscript preserved in Riza Library, Rāmpūr, India, under number Sulūk 938. It was transcribed by hiusayn Shāh Bukhārī র্র̄āiri Rāmpūrī in 1255. The printed edition of Lahore 1351/ 
1933 was not available to us. Cf. Storey, Persian Literature, p. 989, note.

26 See references in note 17 above. The rare al-Risāla fĩ Kayfiyyat "Amal Sulūk al-Nagshbandiyya, n•p., n.d., attributed to SirhindI, is spurious: it mentions persons who lived after Sirhindi's death. See the catalogue of Istanbul Belediye Kutuphanesi, Osman Ergin, no. 39. The book is also not mentioned in the lists of Sirhindi's works quoted in note 17.

27 Zubdat al-Maqāmāt, p. $234^{13-20}$. 28 Malstūbāt, vol. $3, \mathrm{pp} .212-223$. ${ }^{29}$ Persian Literature, volume 1 , part 2, p. 989. The book is also mentioned in Shāh Wali Allāh's Kashf alGhayn fí Sharh al-Rubä'iyyatayn, Delhi 1310, p. 2. In Shāh Walī Allāh's view, Sirhindi's commentary on the Rubāiyyāt only added to the difficulty of understanding them.

$$
\begin{aligned}
& 30_{\text {Maktübāt, vol. } 1, p \cdot 41^{2-20}} \text {. } \\
& 31_{\text {ibid. }} \text { vol. 1, p. } 41^{14-16} \text {. } \\
& 32_{\text {Such as letter } 87 \text { of the third volume which }}
\end{aligned}
$$

aroused much opposition. SirhindI defends his statements in this letter in letter 121 of the same volume. The esoteric nature of many letters in the third volume was recognized by the 19th century writer Wakil Ahmad Sikandarpūri. See Hadiyya rujaddidiyya, pp. $14^{3}-15^{3}$. 
${ }^{33}$ The manuscript is part of the private collection of Professor Khalīa A ḥmad Nizāmī of Aligarh Muslim University, Aligarh, India. I am grateful to Professor Nizâmi for allowing me to use it.

34 See Nizāmi, Hayāt-i Shaykh AAbd al-Hagg Muhaddith Dihlawi. Delhi 1964, p. 312 .

$35 \mathrm{Ma} \cdot \operatorname{är} i j$ al-Wilāya, fols. $621^{15}-665^{11}$. It has been published as an appendix to Nizāmī, op. cit., pp. 312-344.

36 Wa ārij al-Wilāya, fols. 665-708.

37 No information about the author of this work is available.

${ }^{38}$ Al-Nāshira al-Nājira, fol. $1 b^{12-14} ;$ al-'Asab al-Hindi, fol. $1^{4-5}$; Qadh al-Zand, fol $46^{10-11}$.

39 Nanuscript in Așafiyya State Public Library, Hyderabad, India (Kalām 224). It was copied at Awrangābād on Rajab 1, 1157/August 11, 1744 by Zayn al-'Tbidin Muhammad b. Hasan b. 'Abd al-KarIm b. Muhammad alBarzanji. The copyist was a descendant of the author. For al-Barzanjī himself, see Brockelmann, GAL, G II, pp. 388-389; $\underline{\mathrm{S}}$ I, pp. 529-530. 40 Qadh al-Zand, fol. $33 b^{3-6}$ from bottom.

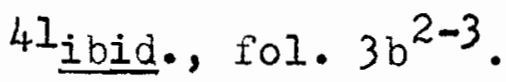
42 Așafiyya Manuscript, Kalām 223. ${ }^{43}$ Al-Nā hira al-Nājira, fol. $26 a^{16-20}$. 
44 ibid., fol. $2 a^{7-9}$.

45 wadh al-Zand, fol. $11 b^{19-20}$; fol. $15 a^{14-16}$.

$46_{\text {ibid. }}$, fol. $3 a^{22 f f}$.

47 Asafiyya Manuscript, Kalām 224. See also

Bankipore Catalogue, vol. 10, no. 579. Al-Sārim alHindi seems to be the same work.

48 Al-A Asab al-Hindi, fol. $1^{4-5}$.

49Al-Nāshira al-Nājira, fol. $1 b^{16}-2 a^{7}$. See

also gadh al-Zand, fol. $3 a^{15 f f} ;$ fol. $79 a^{1-4}$.

50 Al-Nāshira al-Nājira, fol. $2 \mathrm{a}^{3-4}$; al-“Asab

al-Hindi, fol. $1^{7-10}$; Qadh al-Zand, fol. $3 a^{15-16}$.

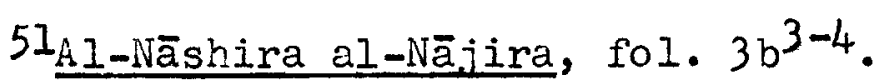

52 Printed in Mucarrab al-Maktūbāt, vol. 3,

margin.

53 ibid., vol. 3, p. 184 , margin.

$54 \mathrm{According}$ to Muhammad Murād there were also

other persons who supported Sirhindi in this controversy.

He mentions especially Hasan b. Muhammad Murād al-Tūnusī

al-Makki, who wrote al-'Arf al-Nadi fi Nusrat al-Shaykh

Ahmad al-Sirhindī. See Mu'arrab al-Miaktūbāt, vol. 1,

p. 77; cf. al-Nāshira al-Nājira, fol. 2b, margin. See

Mu'arrab al-Maktūbāt, vol. 1, pp. 69-77, 123-169 for

details about other persons who wrote in defense of

Sirhind广.

55 
Ganj Collection 24/8, fols. 133a-137b. Preserved in Nawlānā đzād Library, Aligarh Viuslim University, Aligarh, India. The manuscript is corrupt and illegible in many places.

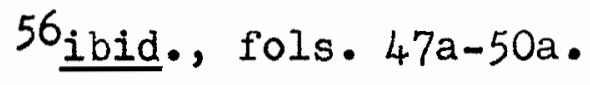

57 B. A. Faruqi, The Wujaddid's conception of

Tawhid. Lahore 1940, pp. 145-170.

58 The name of this work is not mentioned and it may be part of a larger work. It is quoted in Wakil A ḥmad Sikandarpūrī, Hadiyya Mujaddidiyya, Delhi, n.d., pp. 94-96. An Arabic translation of it is given in Mu'arrab al-Maktūbāt, vol. 1, pp. 173-177, margin. 59See the Urdū edition of Tadhkira-yi 'Ulamā' -i Hind, Karachi 1961, p. 597. 60Delhi 1312. See p. $40^{8}$ for the date of composition. Brockelmann's reference to the author of this work as Ahmad b. "Abd al-Ahad al-SirhindI alSikandarpürī (GAL, S II, p. 530) is erroneous. 6IDelhi, n.d. 62Delhi 1309. See pp. $3^{11}-4^{5}$ where Sikandarpūrì describes how Gujarātĩ came to write this book.

${ }^{63}$ India Office MS. D.P. 630. The Urdū translation of this work by Ahmad Husayn Khän, published in Lahore 1922, was not available to us. See EI ${ }^{2}, \mathrm{~s} \cdot v$. Ahmad Sirhindi. 
NOTES TO CHAPTER II

II. Goldziher, Muhammedanische Studien, Halle 1888-1890, vol. 2, pp. 19-22, 56, 58; G.E. von Grunebaum, Medieval Islam, Chicago 1961, pp. 240-241.

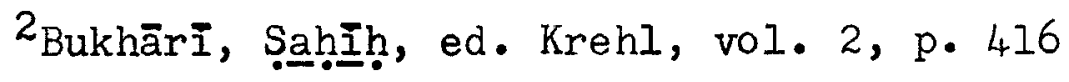

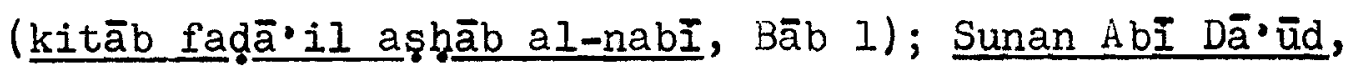
ed. Cairo 1952, vol. 2, p. 518.

3 Sunan Abi Dā' ūd, vol. 2, p. 518 .

4 See, for instance, Sunan Ibn Māja, ed. Cairo 1952, vol. 2, p. 1341 (no. 4040): "Ihe Prophet said: 'I was sent (together) with the Hour like these two.' And he joined his two fingers." (bu“ithtu ana wa al-sā'a ka-hātayn wa jama'a bayna ișba'ayhi). Cf. Șahhịh Muslim, ed. Cairo 1955, vol. 4, pp. 2269-2270 (kitāb al-fitan wa ashrāt al-sāaa, nos. 137, 138). For an analysis of a tradition in a similar vein, but not included in the canonical collections of hadīth, see M. J. Kister, 'A booth like the booth of Moses . .' A study of an early hadith. BSOAS 25 (1962), pp. 150-155.

${ }^{5}$ See, for instance, Sunan AbI Dā. $\bar{u} d$, vol. 2, pp. $429 \mathrm{ff}$, and similar chapters in other collections. 6 The same intention is evident also in another tradition included in the Kitāb al-Malāhim. (Sunan Abi

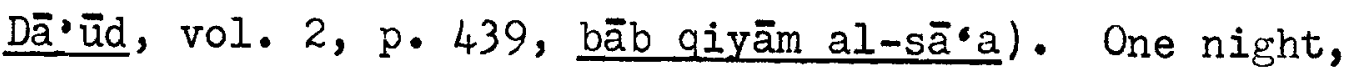


near the end of his life, the Prophet was leading the community in prayer. When it was finished he said: "Have I seen you to night? - because a hundred years from how none will remain on the face of the earth" (a ra'aytukum laylatakum hādhihi fa-inna 'alā ra's mi'a sana minhā lā yabqā mimman huwa 'alā zahr al-ard ahad). Commenting on this version Ibn "Umar says that it is erroneous; the Prophet said according to him: ". . none will remain of those who are to day on the face of the earth - meaning that the generation will come to an end" (. . l lā yabgā mimman huwa al-yawm "alā zahr alard__yurid an yankharim dhālika al-garn). The corrected version is hardly acceptable, but it is indicative of the desire to circumvent the predictions about the imminence of the Hour. Cf. P. Casanova, wiohammed et la fin du monoe, Paris 1911, pp. 17-18.

7.Abd al-Hakīm Siyālkōtĩ was according to the mujaddidi tradition the first man to call Sirhindi by this title. See Khazinat al-Asfiyā, p. $614^{13}$

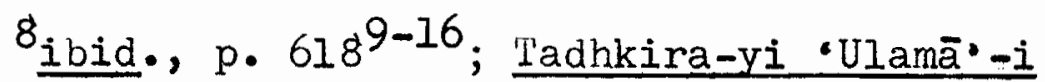

Hind, p. $12^{9-15}$.

9The benedictory formulae following the name of God, the Prophet and other persons have been omitted in all translation appearing in this work.

10 Mabda' O Ma $\bar{a} d, p p \cdot 60^{7}-61^{8}$. Cf. Maktūbāt, vol. I, p. $295^{13-19}$. 
${ }^{11}$ The Lucknow 1889 edition of the Niaktūbāt (vol. 3, p. $174^{5}$ ) reads here āstān-i $\bar{u}$, which is meaningless. The correct version, ummatān-i $\bar{u}$, is found in the Delhi 1290 edition (vol. 3, p. 1785). Anwār Ahmadiyya $\left(\mathrm{p} .82^{12}\right)$, which reproduces this passage, reads ummatiyyān.

$12_{\text {Maktūbāt, }}$ vol. $3, \mathrm{pp} \cdot 173^{8}-174^{9}$. 13 ibid., vol. $1, \mathrm{p} \cdot 305^{5}$.

14 Sabih Muslim, ed. Cairo 1955, vol. 1, pp. 130-131 (kitāb al-īmān, nos. 232, 233); Sahīh alTirmidhI, n.p. 1292, vol. 2, pp. 104-105; Sunan Ibn Māja, vol. 2, pp. 1319-1320 (kitāb al-fitan, no. 15); Sunan al-Dārimî, ed. Damascus 1349, pp. 311-312. See an explanation of the hadīth in Ibn al-Athîr, al-Nihāya fi Gharib al-Hadith wa al-Athar, s.v. gh-r-b. See also Massignon, Essai sur les origines du lexique technique de la mystique musulmane, Paris 1954, pp. 247, 317-318 and Ibn Rajab al-Hanbalī, Ghurbat al-Islām wa yusammāa Kashf al-Kurba bi-Waşf Hāal Ahl al-Ghurba, ed. A hmad alSharbāşI, Cairo 1954 .

150f. Sahịh Huslim, vol. 1, p. 131 (kitāb alİmān, no. 234): "When 'Allāh Allāh' is not said on earth, only then will the Hour take place" (la taqūm al-sā'a hat tā yugāl fī al-ard allāh allāh).

${ }^{16} \mathrm{Cf}$. Sunan Ibn Māja, vol. 2, p. 1319 (no. 3985): 
"Worship during the (last) cataclysm is like fleeing towards me" (al- 'ibāda fí al-haraj ka-’l-hijpra ilayy). See also Maktūbāt, vol. 2, pp. $137^{4-12}$. 17 ibid., vol. 4, pp. 2255, 2268 (kitāb alfitan wa ashrāt al-sā‘a, nos. 110, 131); Sunan Ibn Māja, vol. 2, pp. 1340-1341 (no. 4039).

18 Ilaktūbāt, vol. 2, pp. $135^{17}-138^{3}$. This

letter is partly devoted to the description of a comet seen in India in 1028/1618-1619. It may be of some interest to astronomers.

$$
19_{\text {ibici. }} \text {, vol. } 2 \text {, pp. } 38^{12}-39^{13} \text {. }
$$

20 See Qur.ān 46, 34. Cf. H. Corbin, De la philosophie prophétique en Islam shïite, in Eranos Jahrbuch 1962, Zurich 1963, pp. 70-71.

$2 I_{\text {The text }}$ of the Miaktūbāt is ihyā'-i shari'at-i jadida (vol. I, p. $255^{16}$ ). The passage is reproduced in Zubdat al-Maqāmāt, p. $175^{6-14}$; the text here is binā-yi shari'at-i jadida, which seems to be preferable. 22 An allusion to the hadith: 'ulamä' ummati ka-anbiyā' bani isrāं $\bar{l} l$. 23 Maktūbāt, vol. 1, p. $255^{15-21}$. Cf. Haźarāt al-Quds, fol. $23 \mathrm{a}^{21}-23 \mathrm{~b}^{12}$.

24 It was felt already in the early period of Islamic history that this tradition is not compatible with the sayings indicating that the ideal period of 
the Prophet was followed by an irreversible decline. See Ibn Qutayba, Ta'wil Mukhtalaf al-Hadith, n.p., n.d., pp. 139-141.

25 Maktūbāt, vol. 1, pp. $304^{20}-305^{2} ; 305^{6-11}$; Zubdat al-Miaqāmāt, p. $190^{8-11}$. $26_{\text {ibid. }}$, vol. 1, pp. $299^{21}-300^{4} ; 434^{2-8}$. The appearance of prophetic qualities in persons living in the post-prophetic era through "following and inheritance" (bi taba'iyyat o wirāthat) is one of the frequently recurring themes in the Maktūbāt.

$27_{\text {ibid. }}$, vol. $2, \mathrm{pp} \cdot 14^{17}-15^{4}$. See also vol. $3, \mathrm{p} \cdot 248^{13-18}$, where Sirhind $\bar{I}$ speaks of the mujaddid as the "representative" of "Abd al-kādir al-Jilāni.

28 See infra, p. 159.

29 Qur'ān, 4, 125.

30 Qur.ān 2, 124 .

$31_{\text {Quroān } 16,123 .}$

32 Viaktūbāt, vol. 3, pp. $148^{1}-149^{12}$.

$33_{\text {ibid. }}$, vol. 3 , pp. $166^{14}-169^{12} ; 150^{18}-151^{10}$; $165^{14}$.

34 See supra, note 27 . The brief reference to the mujaddid at the very end of the third volume of the Maktūbāt $\left(\mathrm{pp} .248^{13}-249^{6}\right)$ does not invalidate this statement. Sirhindi only responds there to the possible criticism of the contradictions between his concept of 
tajdId and his later ideas about the mystical role of - Abd al-Qādir al-Jillāni. He does not add anything new to his understanding of tajdid.

35 See supra, note 33 to the present chapter. 36 Maktūbāt, vol. 2, pp. $16^{2}-17^{2}$.

$37_{\mathrm{He}}$ is the author of Zubdat al-Maqāmāt. Thirteen letters have been sent to him; this is the third largest number sent to any single correspondent, with the exceptions of Sirhind's sons Muhammad Sa'Id and Muhammad Ma 'ṣum. See Sirhindi's praise for him in Maktūbāt, vol. 3, pp. $141^{16-20}$.

$38_{\text {ibid. }}$ vol. $3, \mathrm{pp} \cdot 151^{21}-152^{15}$. 
NOTES TO CHAPTER III

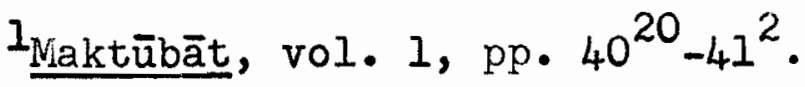

2 Qureshi (The Muslim Community in the Indo-

Pakistan Subcontinent (610-1947), The Hagge 1962, p. 151) says that it was Sirhindi's "spiritual guide who

corrected his exuberance by keeping him within the necessary discipline"; Sirhindi stresses, however, that the correction came to him through divine inspiration. See Maktūbāt, vol. 1, p. $41^{17} \mathrm{ff}$.

$$
\begin{aligned}
& 3_{\text {ibid., vol. } 1, \mathrm{pp} .} 41^{2}-42^{8} \text {. } \\
& 4 \text { see, for instance, Qureshi, 1oc. cit.; S. M. }
\end{aligned}
$$
Ikram, Muslim Civilization in India, New York and London 1964, p. 167; S. A. A. Rizvi, Muslim Revivalist Movements in Northern India in the Sixteenth and Seventeenth Centuries. Agra 1965, p. 259.

5 Maktūbāt, vol. 1, pp. 2-28.

6 ibid., vol. I, pp. $10^{22}-11^{3}$.

7 ibid., vol. 1, p. $16^{5-6}$.

${ }^{8}$ See F. Meier, Alà' al-Dawla al-Simnāní, in $\mathrm{EI}^{2}$

9 al-Quds, fol. $53 b^{14-16}$.

10It is interesting to note that ' $\mathrm{Al} \overrightarrow{\mathrm{a}}$ ' al-Dawla al-SimnānI, who seems to have influenced Sirhindi's 
thinking considerably, also says that his erstwhile adherence to the theory of the Unity of Being helped him to see its falsity later. See Jāmi, Nafahăt al-Uns, Lucknow 1334, pp. 429-440, especially p. 4399ff. I am indebted for this reference to Professor H. Landolt. $11_{\text {Viabda }}$ o Ma $12_{\text {ibid. }}$ pp. $33^{17}-34^{5}$. $13_{\text {ibid. }}$ p. $39^{5-8}$.

14 Naktūbāt, vol. 3, pp. $196^{23}-198^{5}$; Haźarāt al-Quds, fol. $38 \mathrm{a}^{14-21}$.

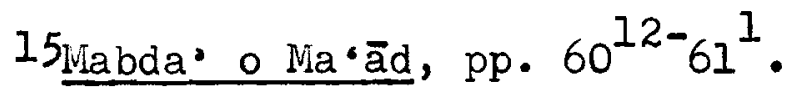

$16_{\text {ibid. }}, \mathrm{pp} \cdot 8^{10}-9^{1}$.

17 Maktūbāt, vol. 3, pp. $170^{14}-171^{3}$.

${ }^{18}$ Letters to Șālin Kūlābi are included in all three volumes of the Maktūbāt (vol. 1, letters 161, 182, 244, 306; vol. 2, letter 33; vol.3, letters 87, 95); this seems to be an indication of the prolonged association between him and Sirhindī. Kūlābi also had access to the letters which Sirhindĩ sent to his sons (Miaktūbāt, vol. $1, \mathrm{p} .263^{18-19}$ ). In one of the letters Sirhindi wrote to him about the death of his sons Muhammad Ṣādiq, Muhammad Farrukh and Muhammad 'Isā (íbid., vol. I, pp. $\left.441^{10}-442^{8}\right)$; this may also be seen as an indication of the degree of intimacy between the two men. Cf. Zubdat al-Maqāmāt, pp. $370^{14}-372^{9}$; according to this 
source Kūlābi was one of Sirhindi's first associates. 199he Lucknow 1889 edition of the Maktūbāt (vol. $3, \mathrm{p} .145^{10}$ ) reads here mutaźammin, which is difficult to accept. We have translated according to the Delhi 1290 edition which has muttasil (vol. 3, p. $149^{10}$ ).

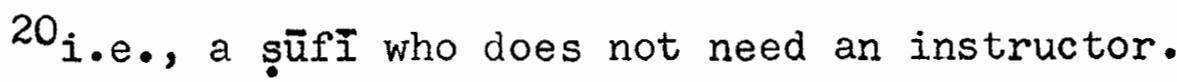
See 'Ațțār, Tadhkirat al-Awliyā', ed. Nicholson, vol. I, p. $24^{7-12}$ : "Know that there is a group of people called Uwaysis. They do not need a pir, because the Prophet, in his own heart, gives them instruction without the mediation of anyone, in the same way as he gave it to Uways. Though he did not meet the Prophet in person, he received instruction from him. In reality, he was (the Prophet's) intimate companion. This is a very high stage . ." Cf. Nicholson, Mathnawĩ, commentary on $4 / 1926$.

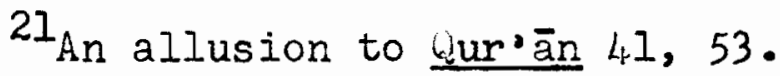

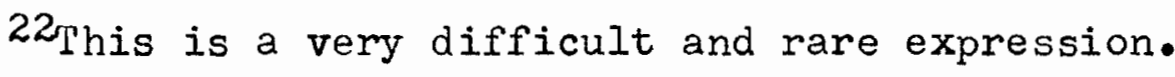
If the text is correct, it may mean "things designed (especially for me (?))".

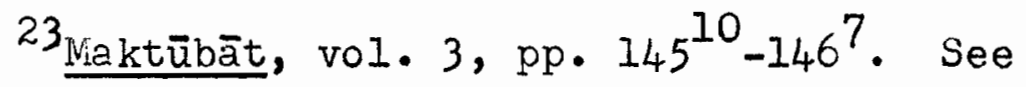
partial translation of this letter in Rizvi, op. cit., p. 268, n. 2 .

24 Naktūbāt, vol. 3, pp. $146^{9}-151^{21}$.

$25_{\text {ibid. }}$, vol. $3, \mathrm{pp} \cdot 151^{21}-152^{15}$. 


\section{6 whe letter which we analysed here is}

addressed to Sirhindi's son and successor, Muhammad Sa'İ.

27 ibid., vol. $2, \mathrm{pp} \cdot 16^{2}-17^{7}$.

$$
\text { 28'Ibn al-'Arabī, Fussūs al-Hikam, ed. 'Afĩfī, }
$$

Cairo 1946, p. 64 . 
NOTES TO CHAPTER IV

$1_{\text {Cf. supra, }}$ p. 23.

${ }^{2}$ Cf. supra, pp. 6-7.

3 Zubdat al-Maqāmāt, p. $131^{11-14}$.

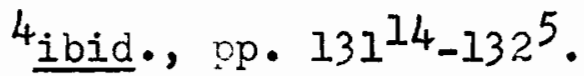

${ }^{5} \mathrm{Cf}$. Sri Ram Sharma, The Religious Policy of

the Mughal Emperors, London 1962, pp. 20-21, 51 (note 57), and V.A. Smith, Akbar the Great Mogul, New Delhi 1962, p. 307 .

6 Ithbät al-Nubuwwa, pp. $5^{15}-6^{14}$. The investtgation of the validity of these charges, which are similar to those levelled by 'Abd al-kādir al-Badā'ūni in his Nuntakhab al-Tawärikh and have been a subject of controversy for a long period of time, is beyond the scope of the present study. For different views regarding them see, for instance, Sharma, op. cit., pp. 23-25, 35-49; Sa‘İd A ḥmad, Iusalmānōn kā curūj o zawāl, Delhi 1963, pp. 306-307; B. A. Faruqi, The Mujaddid's Conception of Tawhid, Lahore 1940, pp. 16-22; Aziz Ahmad, Studies in Islamic Culture in the Indian Environment, Oxford 1964, pp. 167-181. See also Omar S. Pound, The Emperor Akbar as a Religious Man: six interpretations. Unpublished M.A. thesis in the library of the Institute of Islamic Studies, McGill University, Montreal. 
7 See supra, pp. 6-7.

Ithbāt al-Nubuwwa, pp. $6^{14}-9^{18}$. Cf. alGhazāli, al-Munqidh min al-Dalāl, ed. Cairo 1952, p. 43.

9 See supra, pp. 6-7.

$10_{\text {Ithbāt al-Nubuwwa, }}$ p. 10.

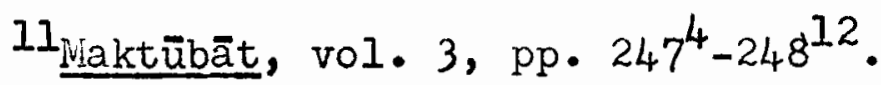

12 Maktūbāt, vol. 1, pp. $150^{23}-151^{14}$. Cf. ibid., vol. $1, \mathrm{p} .153^{6-8}$.

13 ibid., vol. 1, pp. $55^{17}-56^{2}, 24^{11-15}$.

14 ibid., vol. $1, \mathrm{p} .30^{21-22}$.

$15_{\text {ibid. }}$, vol. $1, \mathrm{p} \cdot 291^{15-23}$, vol. $2, \mathrm{p} \cdot 92^{8-22}$.

$16_{\text {Niabda }}$ o Nia $\bar{a} d, p p \cdot 10^{4}-11^{1}$.

17 Qur'ān, 2, 115.

$18_{\text {Viaktūbāt, }}$ vol. $2, \mathrm{p} \cdot 92^{8-22}$.

19 See infra, pp. 98-99.

$20_{\text {Maktūbāt, }}$ vol. 1, pp. $291^{15-23}, 337^{10}-338^{7}$,

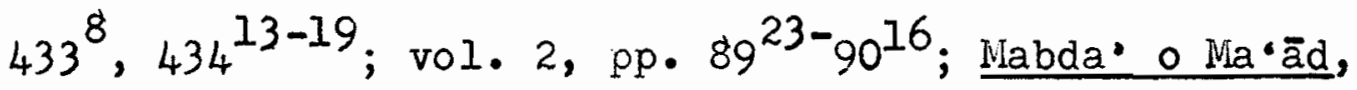
pp. $66^{18}-67^{4}$; Haźarāt al-Quds, fol. $33 \mathrm{a}^{1-2}$; Zubdat alMiaqāmāt, pp. $175^{19-21}, 210^{20-21}$.

$21_{\text {Maktūbāt, }}$ vol. I, p. $191^{12-23}$.

$22_{\text {Mabda o Ma }}$ àd, p. 666-17.

23Maktūbāt, vol. 3, p. 247 $5-10$. The expression gurb-i thubut $\left(p \cdot 247^{6}\right)$ is an obvious corruption of qurb-i nubuwwat. Cf. the Delhi 1290 edition, vol. 3, p. $251^{6}$. 


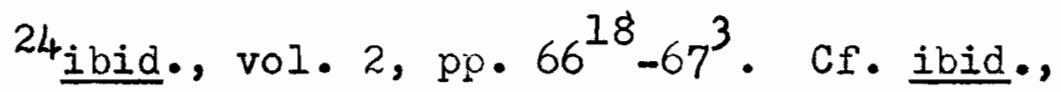
vol. 1 , p. $266^{11-15} ; 337^{2}-338^{7} ; 432^{7}-433^{6}$; vol. 2 , p. $17^{3-7}$.

$25_{\text {See supra, }}$ pp. $34-36$.

26 See supra, p. 24.

27Henry Corbin, De la Philosophie Prophétique

en Islam Shīite, in Eranos - Jahrbuch 1962, Zurich

1963, pp. 49-116, especially pp. 55, 70, 75 . 


\section{NOTES TO CHAPTER V}

I Iaktūbāt, vol. 1, p. 66 $19-20$.

$2_{\text {ibid. }}$ vol. 1, p. $185^{7-12}$; Haźarāt al-Quds, fols. $37 b^{7-10}, 61 b^{1-2}$; Zubdat al-Maqāmāt, p. 21010-17.

3 Haźarāt al-Quds, fol. $37 \mathrm{~b}^{7-10}$.

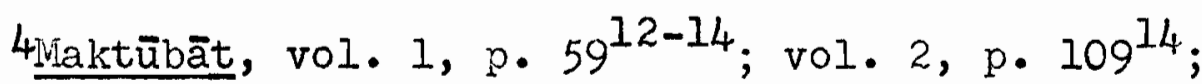

Ma-ärif Laduniyya, fol. $39 a^{\phi-9}$; Zubdat al-Maqāmāt, pp. $231^{20}-232^{1}$. Cf. Maktūbāt, vol. I, p. $55^{2-6}$. The idea expressed in this saying is very old and appears already in al-Sarrāj, Kitāb al-Luma fi al-Taşawwuf, London 1914, p. $215^{12}$ : kull hagiga tukhālif al-shari’a fa-huiwa /sic/ kufr.

5 See Iivurul Hasan, sabd al-Rahīm Khān, in $E I^{2}, \underline{s \cdot v \cdot}$

6 Waktūbāt, vol. 1, pp. $189^{23}-191^{8}$.

7 See Naktūbāt, vol. 1, letters 23, 67, 68, 69, 70, 191, 198, 214, 232; vol. 2, letters 8, 62, 66 .

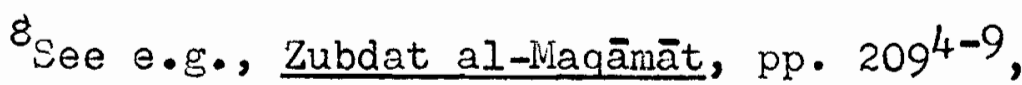
$197^{9-19}$, and infra, note 11 to the present chapter. 9 See infra, pp. 105-106.

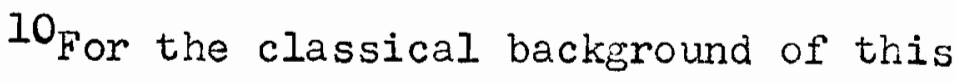
distinction see J. Robson, Bid.a, in $\mathrm{EI}^{2}, \underline{\mathrm{s} . \mathrm{v}}$.

$11_{\text {Viaktūbāt, }}$ vol. I, pp. $71^{1.6-20}, 185^{23}-187^{13}$, $277^{9}-278^{5}, 455^{8-14}$; vol. $2, \mathrm{p} \cdot 32^{7-18} ;$ Mabda o Ma a ad, pp. $45^{2-6}, 65^{7-17}$. 


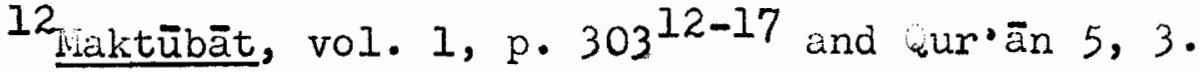
13 Naktūbät, vol. I, pp. $452^{8}-453^{6}$.

14 For a description of these garments see Dozy, Dictionnaire Détaillé des Noms des Vêtements chez les Arabes, Ansterdam 1845, pp. 327-334 (farjiyya, pl. farājI), pp. 203-209 ( 15 iliaktūbāt, vol. 1, p. $246^{11-20}$. 15a liaktūbāt, vol. 3, pp. $53^{20}-55^{12}$. It should of course be understood that the alms are actually given to poor people, in the name of the deceased. For a description of this custom anong the Iuslins in India, see Jaffur Shurreef and G. A. Herklots (translator). Wanoon-e-Islam or the Custorns of the Moosulmans of India, Iondon 1832, pp. 417, 422-425. Cf. also Niaktūbāt, vol. 3, p. $197^{22-23}$, where Sirhindi ordered that "various victuals be brought to the spirituality of the Prophet" in gratitude for the ijāza which the Prophet had written for Sirhind $\bar{I}$ in his dream.

16 liaktūbāt, vol. 1, pp. $358^{9}-359^{11}$; vol. 2, pp. $31^{10}-32^{1}, 95^{13}-96^{11}, 97^{13-22}, 102^{2-9}$; Ma.ārif Laduniyya, fols. $24 a^{11}-24 b^{3}$.

17See Hujwīri, Kashf al-ilah.jūb, ed. Zukowski, p. 2849-11 (translation by Nicholson, London 1911, p. 225). 18 Naktūbāt, vol. 1, pp. $175^{20}-177^{4}$. 
$19_{\text {ibid., }}$ vol. 2, pp. $108^{12}-110^{12}$.

$20_{\text {ibid. }}$, vol. $1, \mathrm{pp} .25^{3-9}, 40^{9-18}, 59^{12-14}$, $73^{4-8}$

$21_{\text {ibid. }}$, vol. I, pp. $50^{8-13}, 55^{1}$.

$22_{\text {ibid. }}$, vol. 1, p. $296^{2-3}$.

23 ibid., vol. $3, \mathrm{p} .224^{22}$; Haźarāt al-Quds,

fols. $52 b^{20}-53 a^{3}$.

$24_{\text {ibid. }}$, vol. 1, pp. $168^{21}-169^{3}$.

25 ibid., vol. $1, \mathrm{p} .100^{3-6}$.

26 The text seems to be corrupt here: o hanafi

or a similar expression must have been omitted.

$27_{\text {Miabda' O Ma } a \bar{a} d}, p p \cdot 38^{17}-39^{2}$.

$28_{\text {Maktūbāt, }}$ vol. 1, p. $365^{13-15}$. Cr. Haźarāt

al-Quds, fols. $39 a^{11}-39 b^{5}$, where Badr al-Din describes

a vision in which Sirhindi was visited by Ábu Hanifa,

al-Shäfi'I and their disciples. In this vision the

lights of Abu thanifa entered Sirhindi; the same happened

later with the lights of al-Shäfi'ī. Badr al-DIn says

that Sirhindi can therefore be called "hanafī shäfi'ī" •

The transformation of the two jurists into mystical

figures is characteristic of the way in which Sirhindi

deals with the shari'a and its leading personalities.

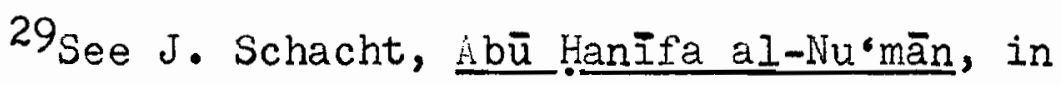

$E I^{2}, \underline{s \cdot v}$ 
30 In this chapter we shall discuss the "ulamā. only as far as their spiritual achievements are concerned. Sirhindi's views on their role in society will be discussed later. See infra, pp. 115-121.

${ }^{31} I_{\text {See }}$ gur.ān, 3, 6 which is the background for the whole discussion that follows.

32 Of al-MarghinānI. See Brockelmann, GAL, G I, p. 376 .

33 Miaktūbāt, vol. I, pp. $356^{22}-359^{16}$; vol.2, pp. $26^{21}-27^{5}, 31^{10}-32^{1}, 112^{6-16}$; vol. $3, \mathrm{p} \cdot 86^{1-18}$; Haźarāt al-Quds, fol. 23a7-19. For another case in which Sirhindi maintains that the bäțin is an indispensable complement of the zāhir, see Maktūbāt, vol. $1, \mathrm{p} \cdot 150^{11-12}$.

34 It would be perhaps instructive to refer here to another place in which Sirhindi speaks of this Gur.ānic verse. In the radd-i Rawäfiź (p. $11^{6-7}$ ), written before Sirhindi joined the Naqshbandi order, he quotes this verse in support of his refutation of the shI'I views. In this period Sirhindi saw the "ambiguous verses" as a source of dissensions in the community; in his şụfi period they became the source of the profoundest religious knowledge. This change reflects the essential transformation of Sirhindi's religious outlook as a result of his affiliation with the Nagshandi order. 
35 For the classical background of this concept and its sister-concept farq or tafriga see Kalābādī, al-Ta arruf li-Madhhab Ahl al-Tașawwuf, Cairo 1960, pp. 119-121.

$36 \mathrm{Cf}$. Miassignon-Kraus, Akhbār al-Hallāj,

Paris 1936, no. 66.

37 See supra, note 35 to this chapter.

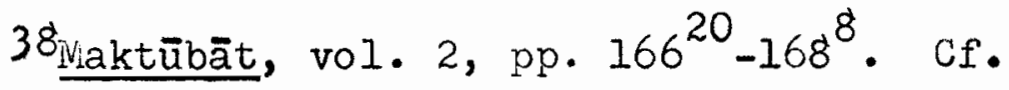
ibid., vol. 2 , pp. $152^{17}-153^{4}$; vol. $3, \mathrm{pp} \cdot 61^{13}-64^{5}$, $162^{13-15} ;$ Mabda' o Ma $\cdot \bar{a} d, p \cdot 48^{14-16}$.

39liaktūbāt, vol. 3, p. $85^{17-20}$.

40 See, for instance, al-Kalābādi, op. cit., pp. $64^{3-7}, 66^{17}, 93^{9-10}$; A. H. Abdel Kader, the Life, Personality and Writings of al-Junayd, London 1962, introduction, pp. 35-37; al-Sarrāj, op. cit., text, pp. $44^{1-2}, 51^{15}-52^{18}, 58^{7}-59^{12}, 60^{10}-61^{14}, 143^{19-21}$, $337^{7-16}, 348^{9-18}$. In Kitāb al-Luma distinction is made mostly between three groups: the common people (al-'āmma, al-mu'minūn), the elect (al-khāsş̧a ) and the elect of the elect (khāşat al-khāşsa). Materials on the attitude of al-Ghazāli, who seems to have held ideas very similar to those of Sirhind $\bar{I}$ on the matter, have been assembled by Hava Lazarus-Yafeh, the Literary Character of al-Ghazaāli's Writings. Studies in the Language of al-Ghazzāli, (in Hebrew), pp. 215-217 
(English Summary, pp. X-XI). Unpublished Ph.D. thesis submitted to the Hebrew University, Jerusalem, 1965.

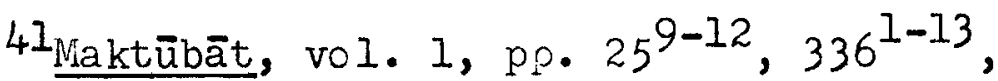
$453^{10-21}$; cf. ibid., vol. $2, \mathrm{p} \cdot 129^{14-23}$. Of particular interest is also a passage in $\mathrm{Mabda}$ o $\mathrm{Ma} \cdot \overline{\mathrm{ad}}\left(\mathrm{p} \cdot 33^{6-8}\right)$ in which Sirhindi says: "It remains to be said that Seeing God (ru'ya) in the hereafter is a reality (haga) in which we believe and are not concerned with its manner (kayfiyya). The reason for this is that the common people are not able to understand it, not that the élite cannot understand it; they (i.e., the élite) (even) have a share in it in this world, though it is not called Seeing." Cf. Maktūbāt, vol. 2, pp. $18^{21}$ $19^{3}$; vol. 3, pp. $244^{12}-245^{19}$; Mabda o Ma a d,$~ p .43^{11-13}$, and supra, chapter 3 , note 17.

$$
\begin{aligned}
& 42 \text { See supra, p. } 6 . \\
& 43 \text { Radd-i Rawāfiź, p. } 1^{8-10} \text {. } \\
& 44 \text { ibid., pp. } 2^{1}-5^{9} \text {. } \\
& 45_{\text {ibid. }} \text { pp. } 5^{9}-23^{3} \text {. } \\
& 46_{\text {ibid. }}, p \cdot 5^{12-16} \text {. } \\
& 47_{\text {ibid. }}, p \cdot 11^{3} \text {. } \\
& 48 \text { ibid., pp. } 10^{19}-11^{1} \text {. } \\
& 49_{\text {ibid. }}, \rho \cdot 13^{12-13} \text {. } \\
& 50_{\text {ibid. }}, \mathrm{p} \cdot 17^{17-22} \text {. }
\end{aligned}
$$


$51_{\text {man ramā rajulan bi-·l-kufr wa qāla caduww }}$

allāh wa laysa ka-dhālika in kāna kamā gāla wa illēa raja"at "alayhi. This tradition is based on the ancient Arab belief about the magic ability of the curse to find out whether it was pronounced justly or not and to afflict the man who pronounced it in the latter case (rujū'al-la'na). See Goldziher, Ueber die Vorgeschichte der Hiǵā-Poesie, in Abhandlungen zur Arabischen Philologie, Leiden 1896, vol. 1, pp. 39, 118. The importance of the curse, which is so prominent in the sunni-shi'i polemics, can be properly understood only against this background.

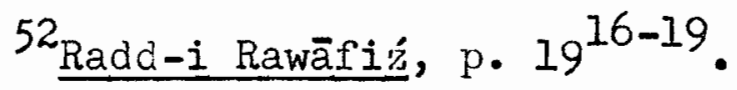

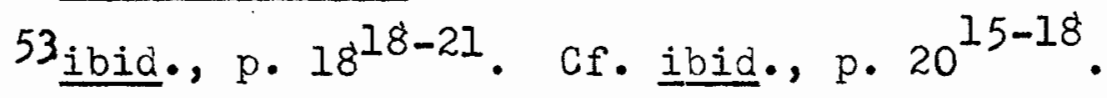

54 ibid., pp. $23^{3}-24$. Cf. Maktūbāt, vol. 2, pp. $63^{11}-64^{16}$.

55 vilaktūbāt, vol. 1, pp. $71^{16}-72^{8}, 104^{13-16}$.

See also Sirhindi's letter to the people of Sāmāna advising them not to overlook the failure of a local khatib to mention the names of all the four khulafa in his khutba (ibid., vol. 2, pp. $28^{4}-29^{14}$ ).

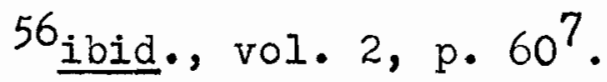

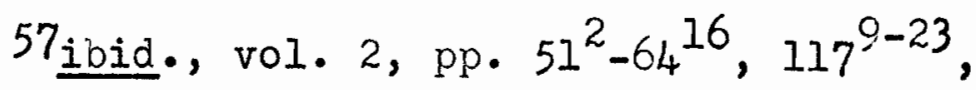
$130^{15}-132^{3}, 168^{8}-174^{9}$; vol. $3, \mathrm{p} .46^{3}-18$. $58_{\text {ibid. }}$, vol. $3, \mathrm{pp} \cdot 247^{10}-248^{12}$. 
59 The text, zĩrakī hālì (?), seems to be corrupt. See Maktūbāt, vol. I, p. $282^{20}$, and cf. the Delhi 1290 edition, vol. 1, p. $282^{19}$ which has zĩrakīhāy.

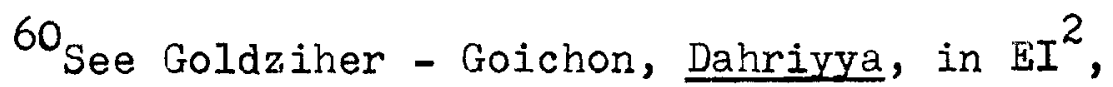
s.v.; al-Ghazāli, al-Munqidh min al-Dalāl, p. 17 7-10; idem., Tahāfut al-Falāsifa, ed. Sulaymān Dunyā, Cairo, n.d. (Dhakhā'ir al-'Arab 15), p. $153^{4-5}$. ${ }^{61_{\text {Maktūbāt, }}}$ vol. I, pp. $282^{16}-283^{3} ; \operatorname{vol} \cdot 3$, p. $38^{14} \mathrm{ff}$.

62 In this connection Sirhindi brings several times a curious anachronistic story about Jesus and Plato. When Jesus' prophetic call was brought to Plato's attention, he said: Whe are rightly guided people and are in no need of anyone to guide us (nahnu gawm muhtadūn lāa hājja lan̄̄ ilē man yahdīnā) ". Sirhind $\bar{I}$ then attacks what he considers to be Plato's stubbornness and stupidity in the strongest possible terms. See Maktūbāt, vol. 1, p. $316^{8-13}$; vol. $3, \mathrm{pp} \cdot 41^{5-8}, 226^{14}-$ $227^{1}$.

$63_{\text {ibid. }}$ vol. I, pp. $315^{5}-316^{8}$; vol. 3 , pp. $23^{4-12}, 38^{14}-43^{2}, 94^{5}-95^{19}$ (especially $94^{16-19}$ ), $193^{1-12} ;$ Mabda'。Ma$\cdot \overline{a d d}, \mathrm{pp} \cdot 47^{11}-48^{5}$. 64 Maktūbāt, vol. 1, pp. $90^{2-17}, 315^{23}-316^{4}$. The attribution of this statement to al-GhazālI's alMungidh min al-Dalāl is inaccurate. Al-Ghazāli 
maintains in al-Munqidh that medicine cannot be learned save by divine inspiration and that the physicians learn about the healing properties of some drugs from the Prophets (pp. $42^{8-12}, 45^{1-7}$; see also p. $23^{6-8}$, where al-Ghazäli speaks of the connection between the political scientists and the Prophets). Nowhere in alMunqidh does he say that the physicians "stole" their science from the Prophets. Al-Ghazāli's intention is to demonstrate the insufficiency of the human intellect in certain fields, not to revile the physicians whose function in society he regards as essential. See also infra, note 67 to this chapter. $65_{\text {Maktūbāt, }}$ vol. 1, pp. $362^{23}-363^{4}$; vol. 3 , p. $30^{5-6}$.

$66_{\text {ibid., }}$ vol. $3, \mathrm{p} \cdot 47^{8-9}$.

67 Sirhindi follows al-Ghazāli's well-known view that the philosophers ought to be considered infidels on account of their views regarding the eternity of the world, their rejection of bodily resurrection and their denial of God's knowledge of the particulars (Tahāfut al-Falāsifa, pp. 305-307; alMunqiah min al-Dalāl, pp. $\left.22^{9}-23^{1}\right)$. The two thinkers differ, however, on other points. While Sirhindi maintains that the philosophers could have never reached the knowledge of the creator without prophetic help, 
al-Ghazāli holds that the naturalists (al-tabíiyyūn) indeed reached it through their observation of the wonders of nature. (Al-Munqidh min al-Dalall, pp. $17^{11}$ $\left.18^{6}\right)$. The main difference between Sirhind $I$ and alGhazāli lies in their respective views of the natural sciences while in Sirhindi's view the study of these is in practically all cases a sheer waste of time, alGhazāli maintains that it is a collective duty of the Muslims ( fard kifāya) to study medicine, arithmetic and geometry in sufficient measure to safeguard the welfare of the community. Physics, astronomy and magic, on the other hand, are useless and ought to be avoided (Ihya. -Ulüm al-Din, Cairo 1939, vol. 1, pp. $23^{1-16}, 29^{3-15}$, $45^{14-18}$; al-Munqidh min al-Dalāl, p. $\left.19^{5-8}\right)$. AlGhazāli's chapter "On the Intellect, its Nobility, its Essence and its Parts" (Ihyā:, vol. 1, pp. 88-95) is also indicative of the difference between the two thinkers in this respect.

$$
68 \text { For the classical background of the term }
$$
bast see Hujwiri, op. cit., pp. $488^{16}-490^{12}$ (translation pp. 374-376). For the connection between the Arabic wajada and the Persian yāftan in the vocabulary of the şūis, see ibid., pp. $538^{13}-541^{17}$ (translation pp. 413416.

69 Ma ārif Laduniyya, fols. $10 a^{4}-10 b^{14}$. 
$70_{\text {Mabda. O Ma }}$ àd, pp. $54^{9}-56^{11}$. For a specific question on which Sirhindi supports the Māturīdiyya as against the Ash'ariyya, - the nature of the attribute of takwin - see liaktübät, vol. 2, p. 11 12-19; vol. 3, pp. $48^{22}-49^{21}$. Cf. Faruqi, op. cit., pp. 117-129 and Abū 'Udhba, Al-Rawdâ al-Bahiyya fimā bayn al-Asha ira wa al-Nāturīdiyya, Haydarābād, 1322, pp. 39-43.

$71_{\text {Goldziher, Vorlesungen über den Islam, }}$ Heidelberg 1910, p. 110.

$72_{\text {See Abu }}$ Udhba, op. cit., pp. $4^{13-14}$ (the text seems to be defective here). The author frequently quotes the views of $A b \bar{u}$ Hanifa instead of those of Mâturĩ two schools of theology. See e.g., p. $32^{5-8}$ and passim. On the question of the relationship between schools of law and schools of theology with reference to the Shāfi'Is and the hsh'aris see G. Makdisi, Ash'ari and the Ash arites in Islamic Religious History, in Studia Islamica 17 (1962), pp. 37-80 and 18 (1963), pp. 19-40. ${ }^{73}$ See supra, p. 66 . 74 See, e.8., letter 67 in the second volume (pp. $125^{2}-135^{17}$ ) which, is the first of two letters sent by Sirhindī to Khān-i Jahān. Of similar content is letter 17 in the third volume (pp. $20^{14}-33^{17}$ ) addressed to an anonymous şūfi woman (șāliha az ahl-i irādat). Cf. also ibid., vol. 1, pp. $89^{13}-94^{15}$. 
NOTES TO CHAPTER VI

$I_{\text {Niaktūbāt, }}$ vol. $3, \mathrm{p} \cdot 64^{6-7}$.

2.

3 Both our editions have here khadamiyyat

which seems to be meaningless in this context.

4 Maktūbāt, vol. 1, p. $57^{8-23}$.

5 The Lucknow edition (vol. 1, p. $58^{4}$ ) reads here hagg ast 0 man which seems to be meaningless. We accepted the version of the Delhi 1290 edition (vol. 1, p. $\left.58^{4}\right)$.

6 Vaktūbāt, vol. 1, pp. $57^{23}-58^{7}$.

7ibid., vol. 1, p. $314^{5-6}$. Qușūri is thus

inaccurate when he says (Na.ārij al-Wilāya, p. 666 $10-11$ )

that Sirhindī considered al-Hallāj a heretic. Cf.

Naktūbāt, vol. $2, \mathrm{p} .81^{2-19}$; vol. $3, \mathrm{p} \cdot 154^{11-21}$.

ibid., vol. $1, \mathrm{p} \cdot 58^{7-9}$.

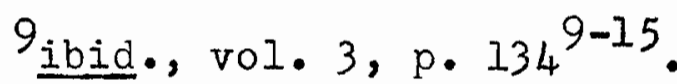

10 Al-Hallāj, Kitāb al-Tawāsin, ed. IHassignon,

Paris 1913, p. 187 .

$11_{\text {liaktūbāt, }}$ vol. $3, p \cdot 154^{11-21}$.

12Miassignon, Al-Hallaj, Martyr Mystique de

I'Islam, Paris 1922, pp. 400-429.

${ }^{13}$ Supra, chapter $V$, section 2 . 
14 Emending mahabbat-i $\bar{u}$ ma'rifat dar sifāt ast O bas of the text ( Kabda' O Ma ād, $p \cdot 47^{8-9}$ ) to mahabbat o ma'rifat etc. according to Zubdat al-liagāmāt, p. $205^{15-16}$.

$15_{\mathrm{Mabda}} \cdot \mathrm{ONa} \mathrm{Ma} d, \mathrm{pp} \cdot 46^{15}-47^{11}$. Cf.

Maktūbāt, vol. 1, pp. $155^{1}-156^{2}$, where Sirhindi says that the preference of the love of God to that of the Prophet is characteristic of Sainthood, while the opposite attitude is characteristic of Prophecy, and ibid., vol. $3, \mathrm{p} .224^{14-18}$. For Kābi'a, see also ibid., vol. 1, p. $228^{2-6}$. For the dream to which Sirhindi refers here see 'Ațțār, Tadhkirat al-Awliyà', ed. Nicholson, vol. 1, p. $67^{5-9}$.

16 Maktūbāt, vol. $3, \mathrm{p} \cdot 230^{11-22}$.

17. op. cit., p. 187; Aziz Ahmad, op. cit., pp. 187-189.

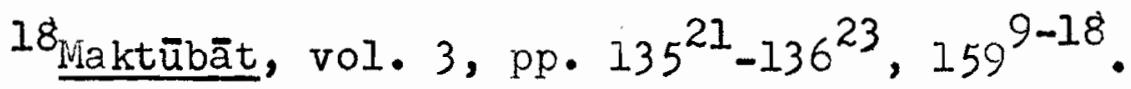

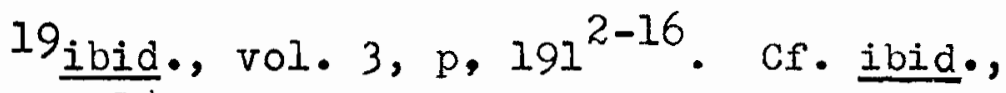
vol. I, p. $314^{18-23}, 374^{4-12}$; vol. $2, \mathrm{p} \cdot 86^{14-20}$; Ma‘ārif Laduniyya, fol. $15 b^{7-15}$; Faruqi, op.cit., pp. 86-91, 99-102. $20_{\text {Maktūbāt, }}$ vol. $1, \mathrm{p} \cdot 42^{1-4}$. $21_{\text {We }}$ say "as he understood it" advisedly. An investigation on our part whether Sirhindi's understanding is correct and duly takes into account all the 
complexities of Ibn al-'Arabi's world-view would be beyond the limits set for this study.

22 Maktūbāt, vol. 1, pp. $160^{3}-163^{7}$; vol. 2, pp. $4^{20}-9^{1}, 175^{8}-179^{8}, 81^{19}-82^{15}$; vol. 3, pp. $109^{16}$ $110^{16}, 111^{2}-112^{16}, 113^{19}-115^{8}$; Faruqi, op. cit., pp. 86-139.

23 Zubdat al-Viagāmāt, p. $210^{1-4}$.

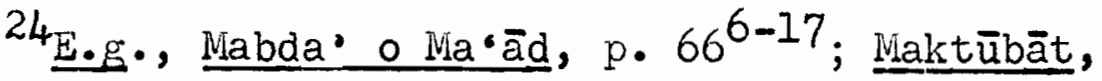
vol. $2, \mathrm{pp} .112^{21}-116^{19} ; \operatorname{vol} \cdot 3, \mathrm{p} \cdot 19^{7-11}$.

$25_{\text {Maktūbāt, }}$ vol. $1, \mathrm{pp} .43^{3-8}, 316^{15}-317^{3}$;

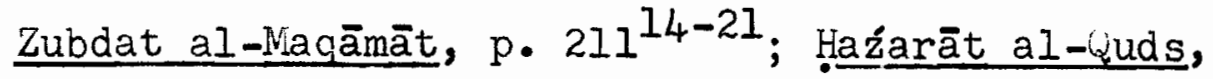
fol. $33 b^{1-3}$.

26 Maktūbāt, vol. 3, pp. $136^{23}-137^{10}$.

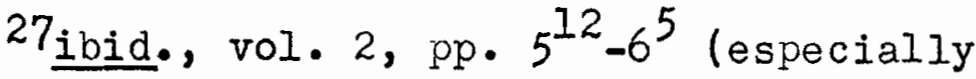
$\left.5^{19-20}\right)$

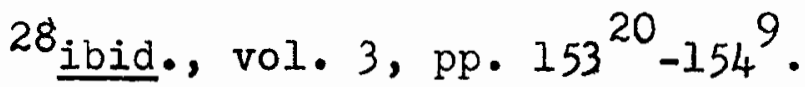

$29_{\text {ibid. }}$, vol. 2, p. $81^{2-19}$; vol. 3, p. $155^{11-16}$.

$30_{\text {ibid. }}$, vol. $2, \mathrm{p} .81^{2-19}$; vol. $3, \mathrm{p} \cdot 157^{4-18}$.

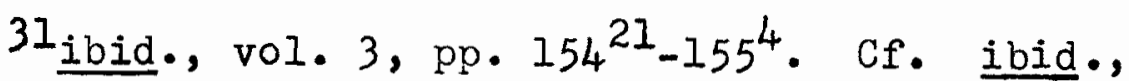
vol. 1 , pp. $133^{3-7}, 410^{12}-411^{3}$; vol. $2, \mathrm{p} \cdot 72^{7-14}$.

$32_{\text {ibid. }}$ vol. $3, \mathrm{pp} \cdot 156^{5}-157^{4}$.

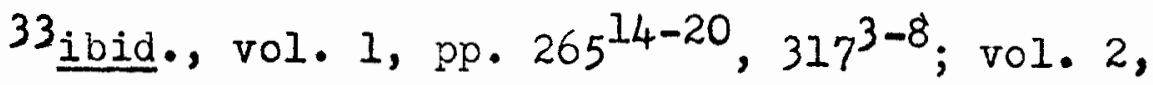
pp. $84^{22}-85^{9}$; vol. 3, pp. $60^{9}-61^{11}$. Cf. Raḥmān $\cdot A l i$, op. cit., p. $11^{7-9}$; Siddīq Hasan Khān, Tiqșār Juyūd al-Ahrō̄r, Bhōpāl 1298, p. 186 
BM. MS, Ethé 645, fol. $436 a^{4-5}$.

34 ibid., vol. 2 , pp. $3^{23}-4^{12}, 177^{8}-178^{3}$;

vol. 3, pp. $156^{5}-157^{4}$. Cf. Hadiyya Mujaddidiyya, p. $99^{3-6}$.

${ }^{35}$ Supra, p. 95.

$36_{\text {Supra, }}$ pp. 49-50.

$37_{\text {Maktübāt, }}$ vol. $1, \mathrm{p} \cdot 160^{2-19}$.

38 Supra, note 22 to the present chapter.

39 Maktūbāt, vol. I, pp. $41^{2}-42^{8}$. Cf. supra,

pp. $29-40$.

$40_{\text {See notes }} 24,26,28,29,30$ to the present

chapter.

$4 I_{\text {Maktūbāt, }}$ vol. 1, p. 161 $1^{4-13}$. Cf. ibid., vol. $1, \mathrm{p} .53^{9-12}$; vol. $3, \mathrm{p} \cdot 89^{8-11}$ (important l).

42 Maktübāt, vol. 1 , pp. $29^{4-6}, 35^{13-14}$, $144^{4-5}, 150^{7-8}, 240^{13-14}, 362^{11-14}, 399^{4-5}$; vol. 3 , p. $14^{8-15} ;$ Mabda' O Ma‘àd, p. $8^{1-9}$.

43 Miaktūbāt, vol. 2, p. $79^{7-23}$.

44 ibid., vol. 1, pp. $74^{3-11}, 399^{1-6}$; vol. 2, pp. $40^{23}-41^{17}$.

$45_{\text {ibid., }}$ vol. 1, p. $364^{11-18}$. $46_{\text {ibid., }}$ vol. $1, \mathrm{pp} .144^{10}-145^{7}, 172^{10-20}$. 47 ibid., vol. 1, pp. $304^{16-20}, 334^{14}-335^{17}$, $367^{9}-368^{5}, 377^{7-17}, 435^{6-9}$. 


\section{NOTES TO CHAPTER VII}

$1_{\text {Maktübāt }}$ vol. 3, pp. $175^{8}-176^{11}$.

$2_{\text {See infra, }}$ pp. 170-171.

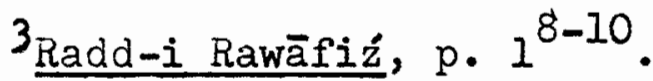

4J. N. Hollister, The ShI·a of India. London 1953, pp. I26ff; Mi. Titus, Indian Islam, Oxford 1930, pp. 89-90; A. S. Bazmee Ansari, Bayram Khan, EI ${ }^{2}$, s.v.; Sukumar Ray, Humayun in Persia, Calcutta 1948, pp. 35-38. ${ }^{5}$ Cf. supra, pp. 59-62.

6 On the question of the historicity of this occasion see W. M. Watt, Wuhammad at Medina, Oxford 1956, p. 230 .

7Maktūbāt, vol. 3, pp. $68^{12}-75^{16}$, especially pp. $69^{15}-71^{1}$. The letter has been partially translated by Rizvi, op. cit., pp. 252-254.

$8_{\text {ibid. }}$ vol. $1, \mathrm{pp} \cdot 284^{7-13}, 284^{22}-285^{19}$; Zubdat al-Haqāmāt, p. $183^{15-19}$; Haźarāt al-Guds, fol. $39 b^{14-18}$.

${ }^{9}$ Cf. supra, p. 77.

10 Maktübāt, vol. 1, p. $284^{13-22}$.

$11_{\text {ibid. }}$, vol. 1 , pp. $68^{23}-70^{7}, 88^{3-16}, 139^{8-14}$, $258^{12-14}, 296^{19}-298^{1}, 334^{11-14}, 436^{7-16}$; vol. 2 , pp. $154^{15}-$ $155^{6}, 156^{18}-157^{8}$; vol. $3, \mathrm{pp} \cdot 31^{13-15}, 59^{5-16}, 144^{15}-$ $145^{7}$; Zubdat al-Maqāmāt, p. $231^{20}-232^{1}$. 
12 ibid., vol. I, pp. $297^{17}-298^{I}$. The "World of Creation" is in a sense superior to the "World of Command" in Sirhindi's thought. See ibid., vol.2, pp. $33^{11}-34^{20}, 143^{8}-144^{5}, 147^{13}-148^{4}, 158^{10-22}$ and L. Gardet, illam (section 2) in $\underline{E I}^{2}, \underline{S} \cdot \mathrm{V}$. ${ }^{13}$ In the beginning of the letter under consideration SirhindI says: "Your two letters have been received. We have understood from them that you love the şüis and seek refuge in this lofty group (i.e. the Naqshbandiyya). What favour it is when one is given this good fortune! Secondly: 'I am telling you that what is necessary for the message / it is up to you whether you will take my advice or be bored by it'". (do kitāb-i shumā rasīd az har do mahabbat-i fugarā. wa iltijā' bi-In țàifa-yi 'aliyya mafhūm gasht čih ni'mat ast kih kasī-rā bi-In dawlat bi-nawāzand thāniyan:

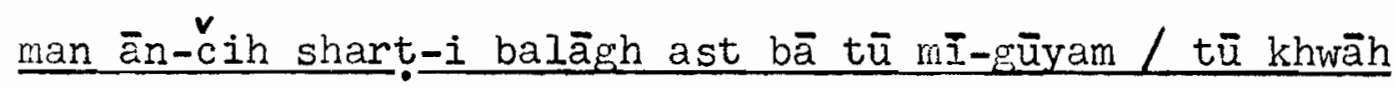
az sukhanam pand gir wa khwāh malāl). The meaning of "What a favour it is . . " is not quite clear; Sirhind may be saying that to be initiated into the Naqshband $I$ order is a great favour, which is not bestowed upon everybody, particularly not upon a Hindū (Niaktūbāt, vol. $1, \mathrm{p} \cdot\left(70^{14-16}\right)$. See also the editor's introduction to this letter, ibid., p. 170 12-14. $14_{\text {ibid. }}$ vol. 1, pp. $170^{12}-171^{16}$. The letter 
has been partly translated by Rizvi, op. cit., p. 254 . Some excerpts are given also in Aziz Ahmad, op. cit., $\mathrm{pp} \cdot 186-187$.

$$
\begin{aligned}
& 15_{\text {Maktübāt, vol. } 1, \text { p. } 171^{2}} \\
& 16_{\text {Haźarāt al-Quds, fol. } 63 a^{9-11}, 87 b^{2-8} \text {; }}
\end{aligned}
$$

Ghulām Sarwar, Khazinat al-Așfiyā', Kānpūr 1898, p. 613 10-14; Muhammad Miyān, Ulamā'-i Hind kā Shandār Mäźi, Delhi 1963, p. 232; Arnold, The Preaching of Islam. London $1913, \mathrm{p} .412$.

17 Wiaktūbāt, vol. 1, pp. $106^{7-15}, 149^{3-11}$, $165^{7}-167^{1}, 169^{14-21}, 193^{11-20}, 339^{2-6}$.
$18_{\text {ibid. }}$, vol. $1, \mathrm{p} \cdot 193^{11-13}$. Quoted in Rizvi, op. cit., pp. 249-250. For the description of the execution and its background see Khushwant Singh, A History of the Sikhs, London and Bombay 1963, vol. 1, pp. 56-62. This author's statement concerning Sirhindi's role in inciting Jahāngir aggainst Arjun (p. 59, note 25) is inaccurate. Sirhind $\bar{I}$ did not write "in strong terms to Jehangir against the Guru"; he wrote to Shaykh Farīd Bukhāri after the execution had already taken place. It is also not true that Sirhindi "claimed to be the second prophet of Islam after Mohammed". Sirhind's's birth date, given here as 1546, is an apparent misprint for 1564. There are some other inaccuracies also in this note. 
19 Maktūbāt, vol. 1, p. $166^{16}$.

${ }^{20}$ In $\underline{\text { Ru} d-i ~ K a w t h a r, ~ K a r a c h i, ~ n . d ., ~ p . ~} 204$,

note.

$$
\begin{aligned}
& 21_{\text {Gur }} \cdot \overline{\mathrm{a}}, \mathrm{5}, 5 . \\
& 22_{\text {cur }} \mathrm{a} n, 9,28 .
\end{aligned}
$$

23 liaktūbāt, vol. $3, \mathrm{pp} \cdot 36^{7}-38^{5}$.

24 Aziz Hhmad, op. cit., p. 185.

25 See references in note 17 to this chapter. 26 He seems to have been particularly interested

in various aspects of the relationship between Isläm and infidelity. In addition to the letter discussed here, see Maktūbāt, vol. 2, pp. $166^{17}-168^{8}$ and vol. 3,

p. $59^{5-16}$. 


\section{NOIES TO CHAPIEE VIII}

IEarly traditions on this question are assembled in al-Ghazāli, Ihyā' ‘Ulüm al-Din, Cairo 1939, vol. 2, pp. 140-154: "On the permissible and forbidden intercourse with the oppressive Sulțāns . . ." (fĩ-māa yuhall min mukhälattat al-salātin al-zalama wa yuhram . . .).

2K. A. Nizāmi, Early Indo-Vuslim mystics and their attitude towards the state. Is Iamic Culture 22 (1948), pp. 387-398; 23 (1942), pp. 13-21, 162-170, $312-321 ; 24$ (1950), pp. 60-71.

3 idem, Nagshbandi influence on Viughal rulers and politics. Islamic Culture 39 (1965), p. 41.

4ureshi, op. cit., pp. 152, 158-159.

5 The Lucknow 1889 edition has here the meaningless min al-istighätha. See the correct version in the Delhi 1290 edition, vol. 1, p. $148^{17}$.

6 According to the Delhi 1290 edition, vol. 1 , p. $148^{18-19}$.

7 Waktūbāt, vol. $1, \mathrm{pp} \cdot 148^{6}-149^{3}$, especially p. $148^{10}, 18-20$.

8ibid., vol. 1 , pp. $145^{7-21}, 145^{21}-146^{7}$, $146^{7-11}$ and especially p. $147^{8-18}$. 9 ibid., vol. $3, \mathrm{pp} \cdot 92^{13}-93^{4}$. 
10 For a description of his career see $B$. Prasad, History of Jahangir, Allahabad 1940, pp. 116, $123-124,130$.

$11_{\text {Maktūbāt, }}$ vol. $1, \mathrm{p} \cdot 66^{2-6}$.

12 Rizvi (op. cit., pp. 225-226) implies that the "ulama'" were invited to the court in order to amuse the emperor by their religious debates, not in order to advise him on matters of the shari.a. Sirhindi's letter, which is the only source from which we know about the matter, does not lend itself to this interpretation. Unless new material relevant to the question is brought to light, Rizvi's interpretation remains highly questionable.

13 Maktūbāt, vol. 1, pp. $70^{6}-71^{3}$.

14 ibid., vol. $1, p \cdot 67^{17-20}$. $15_{\text {ibid. }}$ vol. 1, p. $89^{8-13}$. 16 ibid., vol. I, p. $101^{7-9}$. $17_{\text {ibid. }}$, vol. 1 , pp. $72^{19}-73^{2}$. $18_{\text {ibid. }}$, vol. 1, p. 56 $15-17$. $19_{\text {ibid. }}$, vol. $1, \mathrm{p} \cdot 68^{2-6}$. $20_{\text {ibid., }}$ vol. I, pp. $27^{20}-28^{8}$. See also ibid., vol. $1, \mathrm{pp} .73^{2-11}$, $185^{15-22}$; vol. $2, \mathrm{p} \cdot 19^{3-5}$. $21_{\text {ibid. }}$, vol. $1, \mathrm{p} \cdot 126^{7-9}$. $22_{\text {ibid., }}$ vol. 1, p. $195^{18-22}$. 
$23_{\text {ibid. }}$, vol. $1, \mathrm{pp} \cdot 46^{21}-48^{6}, 64^{23}-66^{11}, 70^{6}-$ $71^{3}, 82^{10}-83^{21}, 193^{21}-194^{2}, 194^{19}-195^{2}, 338^{23}-339^{14}$; vol. $2, \mathrm{p} \cdot 135^{11-17}$ and references in chapter 7 , note 17; Hurtaza Hasan, Letters of Sheikh Ahmad. (A new source of historical study) in The Proceedings of the Indian History Congress, Ninth Session, Yatna 1946, pp. 273-281; Wohammad Yasin, A Social History of Islamic India, Lucknow 1958, pp. 152-153; Àziz Ahmad, op. cit., p. I83; Rizvi, op. cit., pp. 223-234; Miyān, op. cit., pp. 215-230; Ikrām, op. cit., pp. 200-212; NiẓāmI, Naqshbandi influence on lughal rulers and politics. Islamic CuIture 39 (1965), pp. 46-47. ${ }^{24}$ SirhindI praises, for instance, 'Abd alRahīm Khān-i khānān for his faithfulness to the Naqshbandi silsila (Maktūbāt, vol. 2, p. 1219-10). In letters addressed to him there are several passages from which the relationship of Sirhindi with Khān-i Khānān seems to be that of pir and murid (ibid., vol. 1, pp. 85 $\left.11-15,86^{8-12}\right)$. We can see no reason for Rizvi's statement (op. cit., p. 240) that "the letters written by lujaddid to Khan-i Khanan exhibit the constant struggle which lujaddid had to wage to convince him of the correctness of his approach to Islam". 25 For his career see Nurul Hasan, in $\mathrm{EI}^{2}, \underline{\mathrm{s} \cdot \mathrm{v}}$. 
${ }^{26}$ Irfan Habib maintains (The Political Role of Shaikh Ahmad Sirhindi and Shah Waliullah, in Enquiry 5 (New Delhi 1961), p. 42) that "there is no proof that he (i.e. Shaykh Farĩ Bukhārī) received them (i.e. Sirhindi's letters) at all . . ." and that it seems very difficult to believe that such a high official of the Empire would have dared to entertain letters which spoke in abusive terms of the reigning king's father". 'Ihis view is questionable. Shaykh Farīd Bukhārī wrote to Sirhindi at least three times (Naktübāt, vol. 1, pp. $60^{8}, 66^{13-14}, 68^{19-21}$ ) and it is clear that the correspondence was not unilateral. That he was not fearful to maintain contact with Sirhindi is clear also from his material support for Sirhindi's khāngāh (ibid., vol. I, p. $61^{17-20}$ ). The same is true of 'Abd al-Rahịm Khān-i Khānān who also wrote to Sirhindi several times (ibid., vol. $1, \mathrm{pp} .31^{3}, 85^{11-15}$, 86 $6^{9-11}, 197^{11}$ ) and of his son Dārāb Khān (ibid., vol. 1, p. $219^{17}$ ).

27 Nizämi, in Islamic Culture 39 (1965), p. 47. 28 Yasin, op. cit., p. 151 .

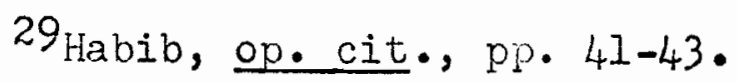
30 Rizvi, op. cit., pp. 219-223.

$31_{\text {These are the dates between which the second }}$ volume of the Maktūbāt, from which the following quotation 
has been taken, was written. See supra, p. 2 . 32 For this place see V. A. Smith, The Oxford History of India, Oxford 1961, p. 56. $33_{\mathrm{A}}$ Hindū fast. See J. A. Dubois, Hindu Manners, Customs and Ceremonies. Oxford 1906, pp. 701-706.

34 Niaktūbät, vol. 2, pp. $161^{23}-162^{10}$. Cf. Habib, op. cit., p. 43; Ikrām, op. cit., p. 202. The view of Professor Nizâmi, who maintains (Islamic Culture 39 (1965), p. 47) that nothing is known about Sirhindi's views of the enperor between the latter's accession and SirhindI's imprisonment, must thus be modifjed. Sirhindi was clearly dissatisfied with the fact that Jahāngir did not introduce stronger measures for the "defense of Islām". Fārūqi (op. cit., pp. 21-22) is wrong when he uses this letter to describe the situation of Islām under Akoar.

\section{Jahängir refers here to letter 11 of the} first volume.

36 (sc. Sayyid Ahmad Khän), Ally Gurh (sc. Aligarh) 1964, pp. $272^{2}$ from bottom $-273^{14}$. Translated in Rizvi, op. cit., pp. 287-288. The same reason for Sirhindi's imprisonment is given in $\mathrm{Ma}$ ärij al-wilāya, p. 666 $15-17$.

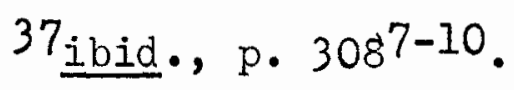


$38_{\text {ibid. }}$ p. $370^{9-6}$ from bottom.

39 Maktūbāt, vol. $3, \mathrm{pp} \cdot 11^{12}-12^{15}$.

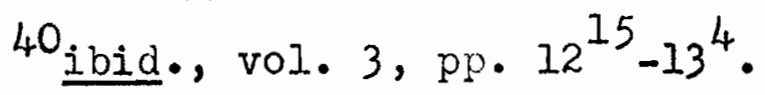

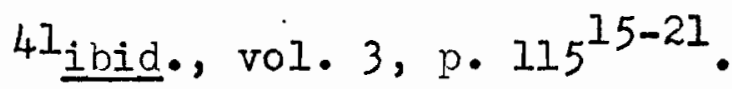

$42_{\text {ibid., }}$ vol. $3, \mathrm{p} \cdot 196^{19-21}$.

43. AzIz Ahmad rejects the idea according to

which Sirhind'i's imprisonment was caused by a shI'I

conspiracy. (Religious and Political Ideas of Shaikh

Ahmad Sirhindi. Rivista degli Studi Oriental1 36 (1961),

p. 261, note 7).

44 ibid., vol. 3, pp. $82^{1}-83^{5}$.

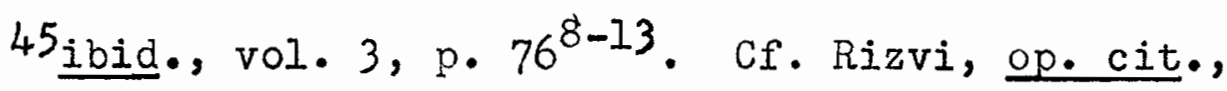

p. 303 .

$46_{\text {ibid. }}$, vol. $3, \mathrm{p} \cdot 76^{8-13}$. 


\section{NOTES T'O CHAPTER IX}

I Wiaktūbāt, vol. 1, pp. $206^{13}-208^{2}, 191^{9-23}$. Cf. Haźarāt al-vuds, fols. $77 \mathrm{a}^{9}-77 \mathrm{~b}^{16}$.

ibid., vol. I, pp. $352^{3-6}, 364^{18-21}$.

$3_{\text {ibid. }}$, vol. 1, pp. $201^{13}-202^{20}, 240^{1-2}$.

${ }^{4}$ See Muhammad Shafi, Abd al-Haga b. Sayf al-DIn in $E I^{2}, \underline{s . v .}$, and Khaliq A hmad Nizāmi, Hayāt-i Shaykh A Abd al-Haog Muhaddith Dihlawi, Delhi 1964. For the letter itself, see supra, chapter I, note 35.

5 See supra, chapter I, note 11 .

6 Nizāmi, Hayāt-i Shaykh 'Abd al-Hagg, pp. $312^{19}-313^{10}$.

7iaktūbāt, vol. 3, pp. $190^{17}-191^{2}$.

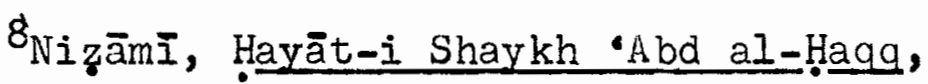
pp. $313^{10}-315^{1}$.

9 ibid., pp. $315^{1}-316^{1}$. Abd al-Haqq's text corresponds fairly accurately to Sirhindi's original. One remark may be useful. On p. $315^{6}$ Nizämi's text reads: man ham murīd-i rasūl allāh am wa ham ham-rah. The manuscript, (Qușūi, op. cit., fol. $624^{13}$ ) actually has the correct ham-pira instead of ham-rah. Cf. Maktūbāt, vol. 3, p. 145 14, and supra, pp. 34-36. $10_{\text {Mlaktūbāt, }}$ vol. $3, \mathrm{p} \cdot 145^{16}$, and supra, $\mathrm{p} \cdot 35$. 


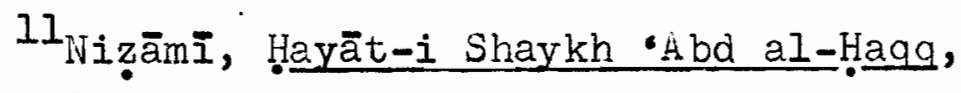

pp. $316^{1}-318^{2}, 318^{11}-319^{3}$.

$12_{\text {ibid., }} \mathrm{pp} \cdot 318^{2-9}$.

$13_{\text {ibid. }}, \mathrm{pp} \cdot 319^{3-20}$.

14ibid., pp. $342^{14}-344$. Cf. Rizvi, op. cit.,

pp. $268-271$.

15 Hadiyya Mujaddidiyya, pp. 104-105.

16 Maktūbāt, vol. $3, \mathrm{pp} \cdot 223^{1}-231^{5}$. The name

of the addressee is not given in our edition of the

Maktūbāt, but it is evident from the content that this

letter in fact is Sirhindi's reply to 'Abd al-Haqu.

17 Hadiyya Nujaddidiyya, pp. $101^{5}-103^{4}$.

${ }^{18}$ One of Sirhindi's closest disciples. See

Niaktūbāt, vol. 1, letters 32, 62, 207, 216, 229, 247,

$248,267,273$; vol. 2, letters 17, 26, 45; vol. 3,

letters $40,72,115$.

19. Abd al-Haqq, Akhbār al-Akhyār, Delhi 1332, po. $323^{24}-326^{6}$.

$2 \mathrm{O}_{\mathrm{T}}$ he following manuscripts have been examined:

a) Bodleian 363 (copied in 1095)

b) India Office D.P. 572 (copied in 1107 from a manuscript corrected by the author)

c) Ethé 640 (no date)

d) Aligarh Muslim University, 'Abd al-Salām oollection 931/26 (copied in 1138) 
e) British liuseum Or. 221 (copied in 1218)

f) Suleymaniya, Istanbul, Esad Ef. 1311 (copied in 1244)

Cf. NizāmI, Hayāt-i Shaykh 'Abd al-Hạag,

p. 202 infra.

$$
21_{\text {Hadiyya Mujaddidiyya, }} \text { pp. } 103^{6}-104^{15} \text {; }
$$

Rahmān 'Alī, Tadhkira-yi 'Ulamā'-i Hind, p. 109 $21-22$;

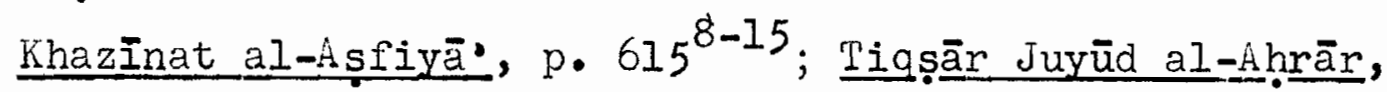
p. $185^{12-18}$.

22 Cf. Nizāmi, Hayāt-i Shaykh 'Hbd al-Haqa, pp. $223-225$.

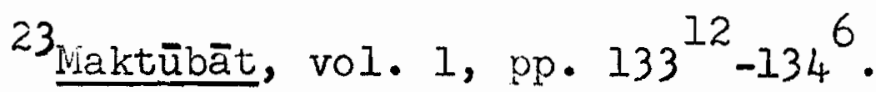

24 See reference in chapter $I$, note 11 , and Appendix A.

${ }^{25}$ See supra, chapter I, section 3 . 26 Maktūbāt, vol. 1, pp. $194^{2-5}, 220^{13}-222^{12}$, $415^{23}-416^{3}$; vol. 2 , pp. $159^{7-16}, 160^{14}-161^{23}$; vol. 3 , pp. $143^{22}-144^{16}$. Cf. Zubdat al-Iviaqāmāt, pp. $256^{2}-258^{3}$, $271^{4}-272^{2}$; Haźarāt al-Quds, fols. $65 \mathrm{~b}^{1}-66 \mathrm{a}^{12}$. 27 Haźarāt al-Quds, fol. 10a $a^{13-15}$. Cf. ibid., fol. $10 b^{4-7}$. $28_{\text {Haźarāt al-Quds }}$, fols. $32 \mathrm{~b}^{14-16}, 67 \mathrm{~b}^{15}$ $68 a^{6}, 70 b^{6}-71 a^{1}, 71 a^{13-21}, 72 b^{12-20}, 73 a^{10-18}, 74 a^{2-11}$, $81 b^{14}-82 a^{3}$; Zubdat al-Magāmāt, pp. $264^{12}-265^{4}, 270^{4}-$ $274^{21}$; Majma. al-Hwliyā., fol. $442 b^{6-10}$. 
29 Haźarāt al-zuds, fol. $72 a^{17}-72 b^{5}$.

30 ibid., fols. $73 b^{10}-74 a^{2}$; Majma al-Awliyā', fol. $441^{1-9}$.

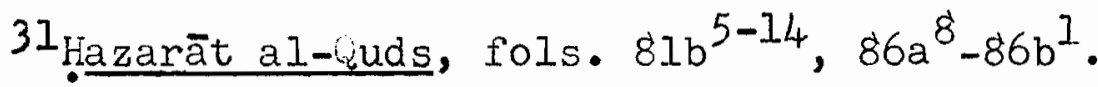

$32_{\text {ibid. }}$, fol. $79 a^{1}-79 b^{13}$.

33 ibid., fol. $39 b^{11-12}$; Zubdat al-Viaqāmāt, pp. $179^{18}-180^{1}$.

${ }^{34}$ Haźarāt al-Quds, fols. $66 \mathrm{~b}^{16}-67 \mathrm{~b}^{10}$; Zubdat al-Maqāmāt $, p p \cdot 264^{3-12}, 267^{12}-268^{16}$; Majma al-Awliyā', fols. $441 a^{9-17}, 443 b^{3}-444 a^{5}$.

35 Haźarāt al-quds, fol. $68^{11-18}$; Zubdat alMaqāmāt, pp. $262^{10}-263^{16}$.

$36_{\mathrm{As}}$ has been done, in our view, by Rizvi, op. cit., pp. 311-313.

37 Haźarāt al-uuds, fols. $70 a^{12}-70 b^{5}, 71 b^{1-13}$, $76 b^{16}-77 a^{2}$; Zubdat al-Naqämāt, pp. $269^{10}-270^{4}, 277^{6-20}$. 38 Haźarāt al-Quds, fol. $74 a^{11-19}$; viajma*alAwliyā', fol. $442 \mathrm{~b}^{10-17}$.

39 Haźarāt al-cuds, fol. $74 \mathrm{a}^{19}-74 \mathrm{~b}^{16}$; Hajmac al-Awliyāo, fols. $442 b^{17}-443 a^{10}$. G. Rizvi, op. cit., pp. 306-310.

40 Haźarāt al-Quds, fols. $63 \mathrm{a}^{9-11}$, $88 \mathrm{a}^{10-17}$. Cf. Anwār Ahmadiyya, pp . $10^{9}-13^{13}$.

41 Zubdat al-Maqāmāt, pp. $281^{10}-282^{5}$.

42 Haźarāt al-uds, fol. $46 \mathrm{a}^{6-10}$. 


\section{Khazinat al-Asfiyä', p. 6́13 16-19. Cf.} Rizvi, op. cit., pp. 286-311.

$$
44 \mathrm{Ma} \cdot \bar{a} r i j \text { al-wilāya, p. } 708^{6-16} \text {. See full }
$$

text in Appendix $B$.

$$
\begin{aligned}
& 45_{\text {ibid. }}, \text { p. } 840 \text { infra } \\
& 46 \text { Qadh al-Zand, fol. } 4 b^{11-18} \text {; al-Nāshira al- }
\end{aligned}
$$

Nājira, fol. $3 b^{15-17}$. See Appendix $C$. The 19th century Naqshbandī writer Wakĩl A ḥmad Sikandarpūrĩ, who learned about the decree from al-Barzanji's Qadh al-Zand only, rejects the authenticity of the decree and considers it a forgery. For him it is inconceivable that Awrangzēb would have issued such a decree after he had been the disciple of Sirhindi's son, iuhammad ina 'șūm (al-Kaläm al-ifunji, p. $27^{16-19}$ ). The truth about the relationship between Hwrangzēb and Muhammad $\mathrm{Na}$ 'ṣum is a matter of controversy (for opposing views see Yasin, op. cit., p. 168; Nizāmī in Islamic Culture 39 (1965), pp. 49-50 and Habib, op.cit., pp. 49-50) and is beyond the limits of this study. In any case, Muhammad Ma șūm had been dead for eleven years when the decree under consideration was issued.

$$
\begin{aligned}
& 47 \text { Ma ārij al-Wilāya, p. } 667^{3-7} \text {. }
\end{aligned}
$$

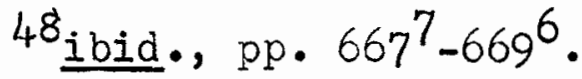

$$
\begin{aligned}
& 49 \text { ibid., pp. } 696^{13}-708^{2} \text {. } \\
& 50_{\text {ibid. }}, \mathrm{p} \cdot 708^{2-5} \text {. }
\end{aligned}
$$


$51_{\text {ibid., pp }} 667^{7}-669^{6}$; cf. supra, pp $25-26$. $52_{\text {ibid. }}$,pp. $669^{6}-673^{3}$.

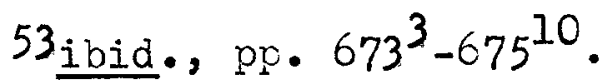

54 ibid., pp. $675^{10}-677^{11}$.

$55_{\text {ibid. }}$, pp. $683^{5}-687^{2}$; cf. supra, pp. 19-20.

56 ibid., pp. $687^{2}-690^{12}$.

57 ibid., pp. $690^{12}-691^{5}$.

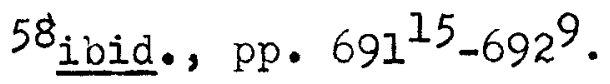

59 ibid., pp. $696^{13}-708^{2}$.

60 See supra, chapter I, notes 52,53 .

61. At.iyyat al-Wahhäb, in Wu*arrab al-Maktūbāt,

vol. 3, pp. 6-7, margin.

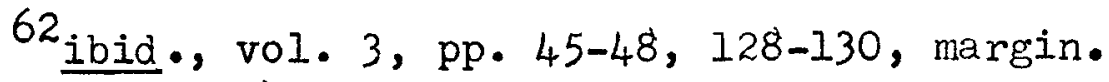

$63_{\text {ibid. }}$, vol. $3, \mathrm{pp} \cdot 48-52 ;$ cf. supra,

pp. $34-36$.

64 ibid., vol. 3, pp. 55-57; cf. Maktūbāt,

vol. 3, pp. $190^{17}-191^{1}$.

65

supra, $\mathrm{pp} \cdot 33-34$.

66 ibid., vol. 3, pp. 136-141, 162-165; cf.

supra, p. 24.

67 ibid., vol. $3, \mathrm{pp} .155-158$.

68 See supra, chapter I, note 47 and pp. 11-12.

${ }^{69}$ Gadh al-Zand, fols. $3 b^{3}-4 a^{13}$. The "ga d.

India" is styled in the letter itself as qädi al-qudāt

bi-Pl-diyār al-hindiyya (ibid., fol. $3 b^{11-12}$ ) and is 
probably the same person referred to in the decree as shaykh al-islam. Since the replies are being sent to him, it can be assumed that he made the decision to send the istifta to al-Hijāz. The introduction to Qadh al-Zand aven says that "the Sulțān of India requested that the 'ulamä' of Makka and of al-Miadina, such as Ibrāhīm al-Kūrānī, Nuhammad al-Barzanjī and others, express their view with regard to the Maktübät of Shaykh Ahmad Sirhindi" (wa al-sabab al-bā'ith litașnif hādhihi al-rasā'il huwa anna sulțān al-hind ‘ālam gin /sic/ istafta 'ulamà' al-haramayn ka-'I-shaykh ibrāhİm al-kūrāni wa al-sayyid muhammad al-barzan,ji wa ghayrahumā 'an maktūbät al-shaykh ahmad al-sirhindi) (ibid., fol. $3 b^{3-6}$ ), but this does not have to be taken literally, and probably means only that the mustafti acted upon the instructions of the emperor. In sadh al-Zand itself, the istifta. is described as coming from the "ulamā" of India" (ibid., fol. $4 b^{10-11}$ ). 70 See Appendix $C$. 71 jadh al-Zand, fols. $5 \mathrm{a}^{3}-9 \mathrm{a}^{26}$. 72 ibid., fol. $11 b^{15-20}$. 73 ibia.., fols. $14 \mathrm{a}^{2-18}, 25 \mathrm{a}^{21}-25 \mathrm{~b}^{2}$; cf. supra, $p .27$.

$$
\begin{aligned}
& 74 \underline{\text { ibid. }} \text {, fol. } 31 b^{14-16} \cdot \\
& 75_{\text {ibid. }} \text { fols. } 9 a^{26}-11 a^{5} \text {. }
\end{aligned}
$$




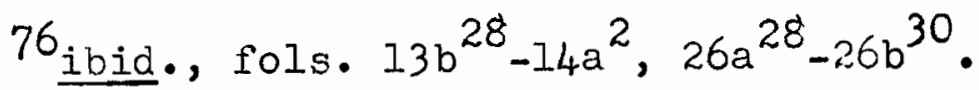

77Jalāl al-Dīn al-Suyūț̃, al-Kashf ‘an

Wujāwazat hādhihi al-Umma al-Alf. See Brockelmann, GAL G II, p. 15I, no. 135 .

78 yadh al-Zand, fols. $14 \mathrm{a}^{28}-14 \mathrm{~b}^{1}$.

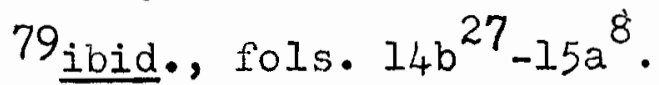

$80_{\text {ibid. }}$, fols. $17 \mathrm{~b}^{21}-18 \mathrm{~b}^{17}$.

$8 I_{\text {ibid. }}$ fol. $18 b^{18-29}$.

$82_{\text {ibid. }}$ fols. $18 \mathrm{~b}^{29}-19 \mathrm{a}^{15}$.

83 ibid., fols. $27 \mathrm{~b}^{27}-28 \mathrm{a}^{15}$.

84 ibid., fols. $32 b^{22}-33 b^{30}$.

$85_{\text {ibid. }}$ fols. $3 b^{30}-4 a^{9}$.

$86_{\text {See supra, }}$ p. 12.

87.

vol. 3, p. 5, margin.

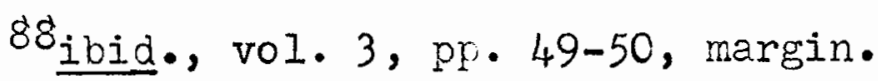

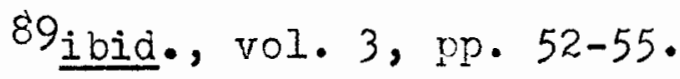

$90_{\text {ibid., }}$ vol. 3, pp. 152-158.

91 al-Nājira, fol. $2 b^{16-17}$. See also kucarrab al-kiaktūbāt, vol. 1, pp. 77-148, margin, where opinions favourable to Sirhind $\mathbf{I}$ are extensively quoted.

$92_{\text {See supra, }}$. 11 .

93 Al-Näshira al-Nājira, fols. $2 b^{4-15}, 3 b^{3}-$ $4 a^{3}, 10 a^{15}-10 b^{2}$. Cf. Appendix C. 
94 Supra, chapter I, notes 13, 14 .

95 in arrab al-ivaktūbāt, vol. 3, pp. 45-48.

96 Muharmad șādiq, Tạaqāt-i Shāhjahānī,

Așafiyya Manuscript, fol. $351 a^{10}-351 b^{2}$.

97 Subhat al-Marjān, pp. $47^{10}-52^{8}$.

98Faruqi, op. cit., pp. 141-149, 181-187 and

Mir Valiuddin, Reconciliation between Ibn 'Arabi's

Wahdat-i-Wujud and the Vujaddid's Wahdat-i-Shuhud, in

Islamic Culture 25 (1951), pp. 43-51.

99 Faruqi, op. cit., pp. 149-170.

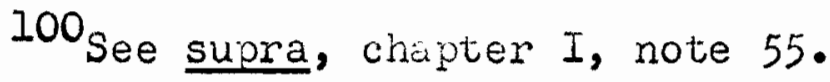

101 Walì Allāh, Rasā'il (Shawāhid al-lajdìd),

fol. $133 a^{1}-133 b^{3}$.

$102_{\mathrm{Cf}}$. supra, $\mathrm{pp} .110$.

$103_{\mathrm{f}}$ he text here is corrupt and unintelligible:

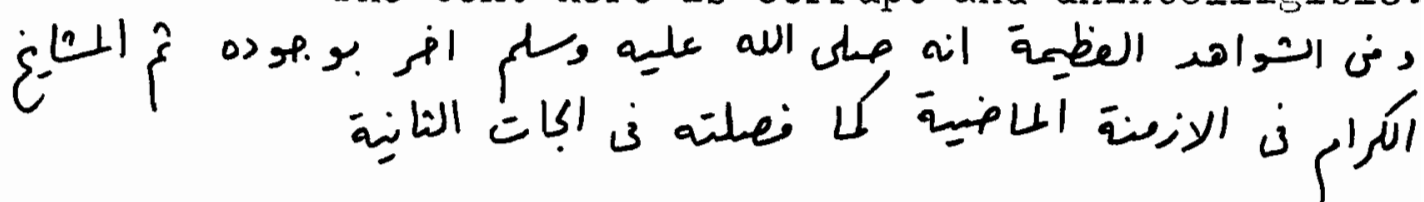

104WaII Allāh, Kasā’il, fols. $133 b^{3}-134 a^{9}$.

$105_{\text {ibid. }}$ fols. $49 \mathrm{a}^{10}-50 \mathrm{a}^{4}$. For the meaning

of irhās see Ion Nianzūr, Lisān al-4rab, s.v. r-h-s.

106 Hadiyya Iujaddidiyya, $\mathrm{pp} .94^{\text {I from bottom }}$

$96^{8}$

107 Supra, pp. 25-27.

108 Supra, p. 14, chapter I, notes 59-62. 
$109_{\text {Al-Kalām al-iun jī, }}$ p. $2^{6}$.

$110_{\text {ibid., }} \cdot 7^{11-18}$; Anwār Ahmadiyya, pp. 3

$11-4^{5}$

$111_{\text {il-Kalān al-ivun,ji, }}$ pp. $10^{4}-13^{10}$.

$112_{\text {ibid., }}$ pp. $6^{23}-7^{8}$.

$113_{\text {ibid. }}$, pp. $7^{19}-10^{3}, 18-27$.

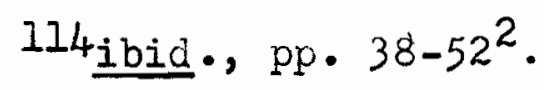

115 Supra, pp. 134-136.

116Cf. supra, pp. 106-108. This claim is not borne out by Sirhind's works.

117 Hadiyya Wujaddidiyya, p. $97^{1-7}$.

118 A bu -Kalān Azād, Tadhkira, Lahore n.d.,

pp. 264-268 and H. Kujeeb, Ihe ladhkira: A Biography in Symbols, in Humayun Kabir, ed., Maulana Abul Kälam Azad. A Hemorial Volume. Ioncion 1959, pp. 134-152, especially pp. 151-152.

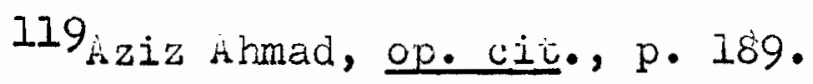

120 livuhammad Hìyān, ULlamā'-i Hind kā Shāndār 率全壬, p. 212 .

$121_{\text {ibid.., }}$ pp. $212-215$.

122 ibid., pp. 249-254. Cf. Wawdūdi, Tajaĩdo Ihya-i Din, Lahore 1953, pp. 86-97; Abul Hasan ali Nadwi, Muslims in Incia, Lucknow n.d., pp. 45-46; s. i. Ikram, lhe spiritual heritage, in 5. I. Ikram, ed., The cultural heritase of Pakistan, Karachi 1955, p. 179. 
Nu·mānI, H. H., ed., al-Furqān hujaddid-i Alf-i thānI Nambar, Bareilly 1357, p. 42; Sa'Id Ahmad, op. cit., pp. 309-310; Subhan, John i., Sufism, its saints and Shrines, Lucknow 1938 (2), p. 282. A. B. M. Habibullah characterizes the historical outlook of this school of Muslim historiography in the following words: "There is little enthusiasm or interest in pre-liuslim India, and Aurangzeb is the national hero, Akbar and Dara Shikoh, traitors to the cause of Islam. Shaykh Ahmad Sarhindi, an orthodox divine of Jahangir's reign who opposed Akbar and Abul razal's (sic) liberalisin, is the true intellectual leader of the Muslins who, together With Aurangzeb, and also with Syed Ahmad Brelvi and Shah Ismail - the nineteenth century Wahabi leader visualized the Muslim state which is now Pakistan." See A. B. M. Habibullah, Historical Writing in Urdu: A Survey of lendencies, in C. H. Philips, ed., Historians of India, Pakistan and Ceyion. London 1961, pp. 494-495.

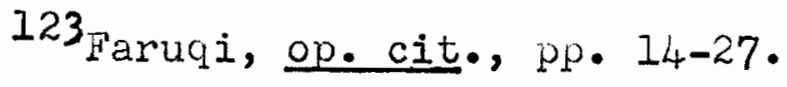
124 ibid., $\mathrm{pp} \cdot 186-187$ and passim. 125 See supra, chapterVI, section 2 . 126 Faruqi, op. cit., p. 187. Cf. Yasin, op. cit., pp. 164-16́5; Hafeez Wik, woslem ivationalism in India and Pakistan. Washington 1963, pp. 52-55. 
127 Qureshi, op. cit., 152-158.

${ }^{128} \mathrm{Ikrām}$, Rūd-i Kawthar, pp. 169-182.

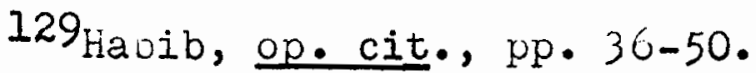

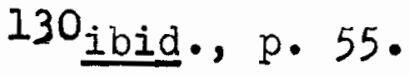

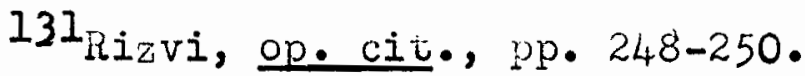

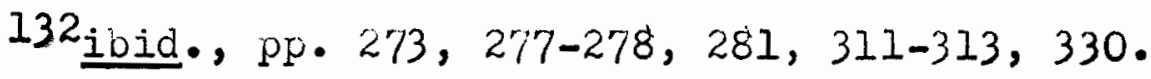

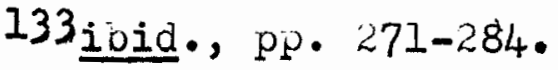




\section{WOPES TO CHATTER X}

$I_{\text {Supra, }}$ pp. 40-53.

2 Supra, pp. 28-29.

3 Supra, p. 56.

4Supra, pp. 33-40. 


\section{BIBLIOGRAPHY}

Only books and articles dealing directly with SirhindI are I1sted in the Bibliography. Works used for purposes of comparison and clarification have been referred to in the appropriate notes.

I.

SirhindI, Shaykh Ahmad, Rì sāla dar Radd-i Rawāfí́. Printed as an appendix to the Maktūbāt.

- Ithbāt al-Nubuwwa. Haydarābād (Sindh) 1383.

Mabda o Ma ād. Delhi,n.d.

Ma ārif Lađunizya. Manuscript in Riza Library, Rāmpūr. Sul̄uk 938.

- Maktūbāt-1 Imām-1 RabbānI. Iucknow 1889. Occassionally collated with the Delhi 1290 edition.

II.

Abbot,Freeland, Islam in India before Shāh WaIIullāh. Studies in Islam, vol. 1, New DeIhi n.d. pp. I-II, 100-II6.

-Abd al-Ahad, Muhammad, Majmū a-vi Hălāt O Magāmāt-1 Imām-1 RabbānI Mujaddid-1 Alf-1 ThānI Haźrat-i Shavkh Ahmad SirhindI. Delhi 1900.

-Abd al-Haqq Muhaddith DihlawI, Akhbār al-Akhyār. DeIh1 1332. 
Ahmad, Aziz, Religious and Political Ideas of Shaikh

Ahmad Sirhindi. Rivista degli Studi

Orientali 36 (1961), pp. 259-270.

- Studies in Islamic Culture in the Indian

Environment. Oxford 1964.

- Trends in the Political l'hought of Medieval

Muslim India. Studia Islamica 17 (1962),

pp. $121-130$.

A b̧mad Sa'İd, Musalmānōn kā 'Urūj o Zawāl. Delhi 1963.

'Ali, Raḥmān, Tadhkira-yi Ulamā'-i Hind. Lucknow 1894 . Ansari, A. S. Bazmee, Djahāngīr, EI ${ }^{2}$.

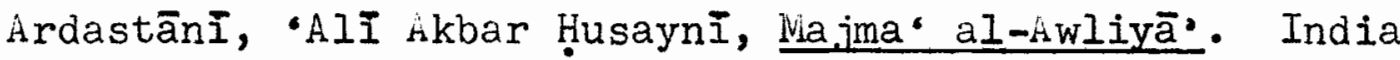
Office Manuscript, Ethé 645 .

Arnold, T. W., The Preaching of Islam. Iondon 1913.

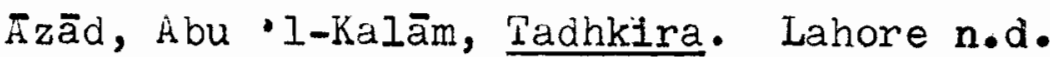

Baig, Mirza wadeer, The Role of Shaikh Ahmad of Sarhind

in Islam in India. Thesis presented for the

degree of Dootor of Philosophy. University

of London, School of Oriental and African

Studies, 1964.

- The two Concepts of Tawhid. Muslim News.

International 2 (July 1963), pp. 29-32, 39.

al-Barzanjī, Miuhammad b. 'Abd al-Rasūl, Qadh al-Zand wa

Gadah al-Rand fĩ Radd Jahālāt Ahl al-Sirhind.

İșafiyya Manuscript, Kalām 224. 
al-Barzanjī, Muhammad b. 'Abd al-Rasūl, al-Nashira al-

Nājira li-·l-Firqa al-Fājira. Aṣafiyya

Manuscript, Kalām 223.

Beale, T. W., An Oriental Biographical Dictionary.

Cawnpore 1867.

Bilgrāmī, Ghulām 'Alī Azād, Subhat al-Marjān min Āthār

Hindūstān. Bombay 1303.

De Bary, Theodore Wm., ed., Sources of the Indian Tradition.

New York 1960, pp. 448-455.

Faruqi, Burhan Ahmad, The Mujaddid's Conception of

Tawhid. Lahore 1940.

Habib, Irfan M., The Political Role of Shaikh Ahmad

Sirhindi and Shah Waliullah. Enquiry 5 (New

Delhi 1961), pp. 36-55.

Habibullah, A. B. M., Historical Writing in Urdu: A

Survey of Tendencies, in C. H. Philips, ed.,

Historians of India, Pakistan and Ceylon.

Lond on 1961, pp. 481-496.

Hasan b. 'Ali, al-‘Asab al-Hindī li-’stīsāl Kufriyyāt

Ahmad al-Sirhindĩ. Eșafiyya Manuscript,

Kalām 224.

Hasan, Murtaza, Letters of Shaikh Ahmad. (A new source

of historical study) (1563-1624 A.D.). The

Proceedings of the Indian History Congress.

Ninth Session. Patna University, Patna, 1946,

pp. 273-28I. 
al-HasanI, "Abd al-Ḥayy, al-Thaqāfa al-Islāmiyya fī alHind. Dansacus 1958.

Husain Khān, Yusuf, Sufism in India. Islamic Culture (1956), pp. 239-262.

Husain, Mahmud, ed., A History of the Freedom Movement. Karachi 1957.

Ikram, S. M., Muslim Civilization in India. New YorkLondon 1964 .

- Rūd-i Kawthar. Karachi n.d.

- The Spiritual Heritage in Ikram, S. M., ed. The Cultural Heritage of Pakistan. Karachi 1955.

Inayatullah, S., Ahmad Sirhind프, in $\mathrm{EI}^{2}$. JahāngIr, Tūzuk-i JahāngIrī, edited by Syud Ahmud (sc. Sayyid Ạ̣mad Khān), Ally Gurh (Aligarh) 1964. KishmI, Muhammad Hāshim, Zubdat al-Maqāmāt. Kānpūr 1890. Malik, Hafeez, Moslem Nationalism in India and Pakistan. Washington 1963.

al-ManzāwI, Muḥammad Murād, Mu'arrab al-Maktūbāt alSharifa al-Marsūm bi-'1-Durar al-Maknūnāt alNafisa. Makka 1316.

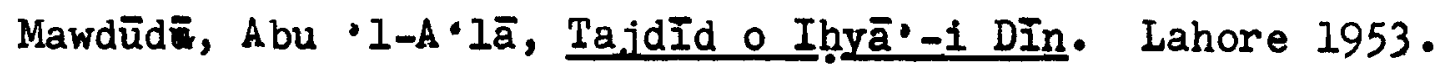
Miyān, Muhammad, ‘Ulamā'-i Hind kā Shāndār Māzí. Delhi 1963.

Nadwi, Abul Hasan Ali, Muslims in India. Lucknow n.d. 
Nizāmī, Khalīq Aḥmad, Hayāt-i Shaykh •Abd al-Hagg Nuhaddith Dihlawi. Delhi 1964 .

- NaqshbandI Influence on Niughal Rulers and Politics. Islamic Culture 30 (1965), pp. 41-52. Nu'māñ̄, Muḥammad Manẓūr, ed., al-Furqān lujujaddid-i Alf-i Thāni Nambar. Bareilly 1357.

- Tadhkira-yi Imām-i Rabbāni Mujaddid-i Alf-i Thāni. Lucknow 1960.

Nurul Hasan, Sayyid, Shaykh Ahmad Sirhindi and Ilughul Politics. Proceedings of the 8th Indian Historical Congress 1945, pp. 248-257. (Was not available to this writerl.

Lureshi, Ishtiaq Husain, The Kuslim Community of the Indo-Pakistan Subcontinent (610-1947). The Hague 1962.

Uușūrī, Ảbd Allāh Khwēshgī, Mukhtasar Nia ārij al-Wilāya fī Madārij al-Hidāya yā Ma ‘ārij al-Awliyāo fĩ Madärij al-Asfivā. Manuscript in the private collection of Professor Khalĩ Ạmad Nizāmi, Aligarh Muslim University, Aligarh, India. Rizvi, Saiyid Athar Abbas, Muslim Revivalist Movements in Northern India in the Sixteenth and Seventeenth Centuries. Agra 1965.

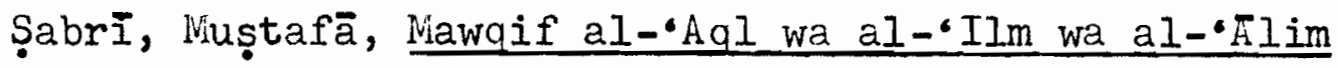
min Rabb al-'Alamin wa 'Ibādihi al-Miursalin. 
Cairo 1950, vol. 3, pp. 275-315.

Ṣādiq, Muhammad, Ṭabaqāt-i Shāhjahānī. Fṣafiyya Nianuscript, Ta'rikh 72l.

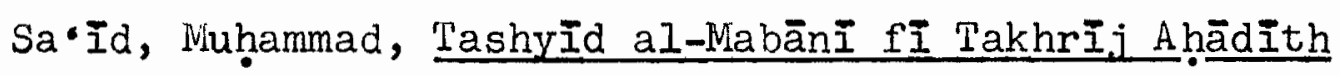
al-Imām al-Rabbān̄i. Haydarābād (Dakhan) 1311.

Sarwar, Ghulām, KhazInat al-Așfiyā: Kānpūr 1902. Shafi, Mohammad, sAbd al-Haga b. Sayf al-DIn. $E I^{2}$. Sharma, Sri Ram, The Religious Policy of the Mughal Emperors. Iondon 1962.

Ṣiddīq Ḥasan Khān, Wuhammad, Tịgșār Juyūd al-Ạhrār fī Tidhkār Juyūd al-Abrār. Bhōpāl 1298. Sikandarpūri, Wakīl Ạ̣mad, Anwār Ahmadiyya. Delhi 1309. - Hadiyya Mujaddidiyya. Delhi n.d.

- al-Kalām al-Munji ji-Radd Irādāt al-Barzanjī. Delhi 1312.

Sirhindī, Badr al-DĪn, Haźarāt al-luds. India Office Mlanuscript, D.P. 630.

Smith, Wilfred Cantwell, The 'Ulama' in Indian Politics in C. H. Philips, ed., Politics and Society in India. Iondon 1963, pp. 39-51.

Subhan, John A., Sufism, its Saints and Shrines. An introduction to the study of Sufism with special reference to India. London 1938 (?). 
al-Ozbakī, Muhammad Bēg, ¿Atțyyat al-Wahhāb al-Fāșila bayna al-Khața wa al-Șawāb. Printed on the margin of the third volume of al-Manzāwi, Mu'arrab al-Maktūbāt. (see supra). Waliuddin, Mir, Reconciliation between Ibn 'Arabi's Wahdat-i-Wujud and the Nujaddid's Wahdat-iShuhud. Islamic Culture 25 (1951), pp. 43-51. Walì Allāh, Shāh, Fayșala-yi Wahdat al-Wujūd wa alShuhūd. Delhi, n.d.

- Kashf al-Ghayn fĩ Sharh al-Rubā'iyyatayn. Delhi 1310.

- Shawāhid al-Tajdīd in Rasāंil-i Haźrat-i Shāh Walì Allāh. Habīb Ganj Collection 24/8, fols. 133a-137b. Preserved in Mawlānā Azād Library, Aligarh Muslim University, Aligarh, India.

Yasin, Mohammad, A Social History of Islamic India. Lucknow 1958. 